\title{
Under Construction:
}

National identity and the display of colonial history at the National Museum of Singapore and the Museum of New Zealand Te Papa Tongarewa

By

Julia Waite

A dissertation submitted in partial fulfilment

of the requirements for the degree of

Master of Museum and Heritage Studies

Victoria University of Wellington, New Zealand

2008 


\section{Table of Contents}

\section{Page}

Abstract

iii

Acknowledgements

iv

List of Illustrations

V

Introduction:

1

Chapter One:

Chapter Two:

Chapter Three:

Conclusion:

Illustrations

76

Bibliography

86 


\begin{abstract}
In New Zealand and Singapore, national identity is inextricably linked to the processes of colonisation, decolonisation and the gaining of political independence. Unlike highlytheorized accounts of national identity, this study provides a deeper understanding of the ways in which it is actually developed, materialised and negotiated in 'real world' examples through history exhibitions at Te Papa and the National Museum of Singapore. The research provides a fresh perspective on recent displays of colonial history and how they shape and are shaped by the concerns of present-day nation-building particularly in former British colonies including Asia. It seeks to move beyond the existing literature which has been concerned with deconstructing national identity as a cultural construct to consider the ongoing process of updating, remaking and maintaining identity through museum display.
\end{abstract}

Using a qualitative approach, this dissertation incorporates archival research, interviews, theoretical and historical literature, and visual analysis of exhibitions to contextualise and analyse the similarities and differences in the history exhibitions mounted at these two recently redeveloped museums. The Day 1 history exhibitions at Te Papa, opened in 1998, form the core of this study, while the chapter on Singapore provides an added layer of comparative depth, helping to broaden the picture of national museums and nationalism more generally.

This research explores how national museums negotiate, on the one hand, the material and intellectual legacy of previous inherited definitions of 'the nation', while on the other responding to the contemporary expectations which arise from present-day conceptualizations of nations and national identity. My findings suggest that the construction of national identity is not independent from socio-political contexts, and that the political ideals of multiculturalism and biculturalism helped to foster inclusive and politically harmonious visions of national identity in the National Museum of Singapore and Te Papa. The conclusion argues that national museums' participation in the public articulation and definition of a collective idea of 'the nation' is unstable, contradictory and contested but nonetheless worthy of serious academic research. 


\section{Acknowledgements}

I must first thank my supervisors, Dr Conal McCarthy and Dr Adrian Muckle, both at Victoria University. Their guidance, encouragement and patience are greatly appreciated.

I would also like to acknowledge those who supported my research: Jock Phillips, Bronwyn Labrum, Paul Thompson, and Kirstie Ross who all provided extremely insightful interviews. Thanks must also go to Iskander Bin Mydin at the National Museum of Singapore who provided responses to my questions by email. Thanks to Jennifer Twist, Te Papa's archivist, who also assisted me in my research. Thanks to Ann Walker, for helping format my images and a special thanks to the proofreaders Brent Taylor and Shannon Austin, who made time to proofread this dissertation while caring for her new baby.

This dissertation is dedicated to my parents, Janet and David, and my brother, James, whose support and love were undiminished. 


\section{List of Illustrations}

Figure 1: May Wong display, National Museum of Singapore. 2008. Photograph Julia Waite

Figure 2: Amahs display, National Museum of Singapore. 2008. Photograph Julia Waite

Figure 3: Rickshaw Singapore display, National Museum of Singapore. 2008. Photograph Julia Waite

Figure 4: bricks in Richshaw Singapore display, National Museum of Singapore. 2008. Photograph Julia Waite

Figure 5: Chasing the Dragon display, National Museum of Singapore. 2008. Photograph Julia Waite

Figure 6: Opium "bed" in Chasing the Dragon display, National Museum of Singapore. 2008. Photograph Julia Waite

Figure 7: Munshi Abdullah display, National Museum of Singapore. 2008. Photograph Julia Waite

Figure 8: William Farquhar display, National Museum of Singapore. 2008. Photograph Julia Waite

Figure 9: William Read display, National Museum of Singapore. 2008. Photograph Julia Waite

Figure 10: Portrait of Cecil Clementi Smith, National Museum of Singapore. 2008. Photograph Julia Waite

Figure 11: Portrait of Sir Frank Swettenham, National Museum of Singapore. 2008. Photograph Julia Waite 
Figure 12: Portrait of Sir Sir Shenton Thomas, National Museum of Singapore. 2008. Photograph Julia Waite

Figure 13: detail sketch of Signs of a Nation exhibition, Exhibitions Conceptual Design 1994, 2008 Photograph Julia Waite.

Figure 14: detail sketch of Encounters exhibition, Exhibitions Conceptual Design 1994, 2008. Photograph Julia Waite.

Figure 15: Signs of a Nation exhibition Te Papa, 2009. Photograph Julia Waite.

Figure 16: Entrance to Passports exhibition Te Papa, 2009. Photograph Julia Waite.

Figure 17: The Rescue of John Guard, C. Watson, 1884, on display in Passports exhibition Te Papa, 2009. Photograph Julia Waite.

Figure 18: Entrance to Exhibiting Ourselves exhibition Te Papa, 1998.

Figure 19: Entrance to On the Sheep's back exhibition Te Papa, 1998. 


\section{Introduction}

Since the nineteenth century, when modern public museums emerged at the same time as nation states, it has been recognised that the displays in these institutions have a role to play in 'the making of ourselves' (Kaplan 1994). Despite the close connections between national museums and national identity, Fiona McLean argues that scholars need 'a deeper understanding of the ways in which museums negotiate and construct meanings of national identity' (McLean 2007, 329). This dissertation seeks to fill this gap in scholarship by exploring the construction of national identity through the representation of colonial history in the National Museum of Singapore (NMS) and the Museum of New Zealand Te Papa Tongarewa (Te Papa).

In the 1970s national museums started redeveloping in an attempt to present more inclusive and pluralist histories (Karp et al 1992, Kaplan 1994, Simpson 1996). In former settler colonies, including Australia, Canada and New Zealand, national museums were redefined in the 1980s and 1990s to more adequately represent multiracial societies. The National Museum of Singapore, which re-opened at the end of 2006 after extensive redevelopment, is a more recent example of a national museum which reinterpreted its colonial history in relation to current socio-political concerns, including the urgent need to forge a unified national identity in a diverse multicultural society. In New Zealand, planning began for a new national museum in 1985. In 1992 The Museum of New Zealand Te Papa Tongarewa Act declared that this institution should 'provide the means for every such culture to contribute effectively to the Museum as a statement of New Zealand's identity' (Department of Justice [DJ] 1992, 2). Te Papa opened in 1998, with several new history exhibitions that were seen as reconciling the colonial past with a bicultural present in which Pakeha (descendents of European settlers) and indigenous Māori lived together in one nation.

The contemporary world in which we live is a product of colonialism (MacQueen 2007, 25). In former British colonies like New Zealand and Singapore, national identity is interwoven with their colonial roots. New Zealand and Singapore are relatively small 
postcolonial countries which have struggled to form new national identities in an era of political independence. Despite the many differences between them, these themes of multiculturalism and biculturalism are central to both countries' nation-building projects, as the countries' governments established flagship national museums with the objective of nurturing national identity. There is merit, therefore, in a comparative approach that examines the national museums of these two countries together in the same framework.

The central research question is: how does the museum representation of colonial history shape the construction of national identity? Much has been written about the recent development of 'new museums' and the ideological and discursive factors, including globalization and nationalism, which produced them (Boswell and Evans 1999, Healy and Witcomb 2006, Message 2006, Williams 2003). However, this study does not simply imply that history exhibitions are products of government policy but, like other recent studies, argues that they are shaped and reshaped by local cultural and historical forces (Archibald 2007, Mason in Macdonald, 2006). Using historically-grounded analysis of the distinctive contexts which created the history exhibitions at the NMS and Te Papa, this study of nation-building through history exhibitions in national museums provides deeper insights into the nature of identity-formation, the development of the institutions themselves and the populations they represent.

\section{Literature review: History, Identity and 'the New Museology' in National Museums}

Museums were invented at about the same time as modern nation states themselves, and in the last few years many scholars in museum studies have debated the central role that museums have played in the construction of national identity. In the following literature review, the research question is examined through several related bodies of writing on museums and the new museology, the presentation of history in museums, and nationalism and national identity. In doing so, an interdisciplinary approach to the topic is formulated, which expands museum studies by incorporating theories from history, cultural studies and related fields (Macdonald 2006, Mason in Macdonald, 2006). 
The NMS and Te Papa were redeveloped under the influence of the 'new museology', a term used to describe the critical re-examination of the role of museums in society. Peter Vergo, who coined the term, described it as; 'a state of widespread dissatisfaction with the "old" museology... what was wrong with the "old" museology is that it is too much about museum methods, and too little about the purposes of museum' (Vergo 1989, 3). It was argued that museums traditionally were institutions whose priorities lay more with artefacts than visitors (MacDonald \& Alsford 1991, 305; Hudson 2004, 85), and whose allegiance was to the dominant ideology of the cultural elite (Prior 2006, 519). From the 1980s many museums, including the NMS and Te Papa, were transformed into democratized sites whose primary concern lay with serving the public (Hudson 2004, 85). Scholars argue that prior to 'the new museology' of the 1970s, a movement which prioritized education, social change and community development, most museums did not cater to the public as they do today (Kreps 2003, 9-10). The museum's function at that time was different: through its structure and content the museum enlightened visitors with 'society's most revered beliefs and values' (Duncan \& Wallach 2004, 52). Visitors came to be awed and filled with wonder, wrote Hudson, and were 'in no sense partners in the enterprise' (Hudson 2004, 85). The new museology concerned itself with 'involving the public, not just during the visit to the museum through interactive displays, but also in the production of their own pasts' (Walsh 1992, 161). As 'new museums' developed, the role of the visitor changed from passive viewer to involved patron (Hudson 2004, 91). Historically, Hooper-Greenhill points out, museums were subject to the whims of people in power, the politics that surrounded them, and the social context they inhabited (Hooper-Greenhill 1992, 72). As museums emerged from 'specific historical experiences' (Muise 1989, 10) more and more they reflected the values and trends of their time. Museums were originally linked to high culture and aristocratic values, which naturally led to the supporting and perpetuating of 'dominant values or recognition of the dominant culture amongst the populace' (Merriman 1989, 165). Many of the new and redeveloped museums today, in contrast, reflect the fact that political power has dispersed and society has become more open, democratic, and less patriarchal. 
As part of the new museology theorists began investigating the role of history in museums (Coombes 1991, Crane 2000, Macdonald 1998, Schlereth 2004), revealing the role of history exhibitions in developing and reinforcing a country's sense of nationhood (Allen and Anson 2005, Crane 2000, Phillips 1996, Witcomb 2003). Using history collections and exhibitions, museums form and maintain national cultural consciousness by making themselves indispensable in "uniting the various social groups within their countries' (MacDonald and Alsford 1991, 310). Museums achieve their goals through memory and communication: by serving as their nation's connection to the past, by conveying that past to both citizens and non-citizens (Archibald 2006, 4), and by fostering the impression of 'continuity and enduring identity' (MacDonald and Alsford 1991, 39). They are capable of creating common public spaces for increasingly fractured societies (Beire-de Haan 2006, 1996), and projecting a 'landscape of power, assigned to documenting the giant steps taken by the nation's history' (Pieterse 2005, 176). Through their display of history, national museums are credited with playing an important social role by both reflecting and shaping their audience; emphasizing certain qualities of the nation and ignoring others; and creating inclusiveness for some while excluding others. National museums are:

...now widely understood as secular sites of contestation and representation, and as places where groups vied with each other to define and redefine "themselves" as nations (Kaplan 2006, 165).

Inextricably linked to the values and achievements of the past, national museums have a strong connection with ongoing socio-historical concerns, including the construction of national identity. This research explores how the new museum philosophies and practices were put into practice by examining the 'meaning' behind exhibition display (Stam 1993), and analysing history exhibitions as the primary site for the construction of national identity. 'The new museology', and critical museum history in general, argued that we cannot separate the exhibition from the museum or the method from the meaning of the institution (Corrin in Carbonell, 383). According to Mason,

...national museums can be understood to be 'of' the nation and 'for' the nation but equally that the definition of the nation upon which national museums are premised invariably changes (Mason 2007, 87). 
Influenced by the new museology, museum professionals, critics and writers began interrogating museum exhibitions as a complex set of internal practices in their own right quite apart from their incorporation of national concerns and broader international museum trends. Previously exhibitions were often presented as 'unequivocal statements rather than as the outcome of particular processes' (Macdonald 1996, 4). According to McCarthy, much has been written on the history of museums and their collections, while exhibitions have been largely overlooked (McCarthy 2007, 7). Other scholars argue that exhibitions were often regarded as a "natural form" and the actual work exhibitions do on and through audiences was largely neglected' (Ferguson in Greenberg, Ferguson and Nairne 1996, 178, 175). The new approach adopted in this study 'calls for an analytical approach' taking the exhibition's social context into account (Macdonald in McCarthy 2007, 8).

Much has been made in museum studies of exhibition content, but 'there has been little about its form' (Ward in McCarthy 2007, 8). This dissertation includes the visual analysis of a selection of history exhibitions, as well as a brief analysis of the exhibition's internal development process. Mason has highlighted the need to consider not only the 'historical, macrocosmic reasons for why a museum representation has come to be as it is, but also the effects of practical current factors like marketing, audience development, visitor profiles and visitor surveys' (Mason 2007, 19). Exploring particular redevelopment projects at Te Papa and the NMS reveals some of the broader national and global process, as well as contemporary museological practices which have shaped their history exhibitions.

There has been little academic study of the NMS. However, the role of history in national museums in Asia has formed the basis of a select group of studies (Hue-Tam Ho Tai 1998, Muan 2002, Pai 1996). In Rubie S. Watson's essay 'Tales of Two “Chinese” History Museums: Taipei and Hong Kong,' the subjective and transient nature of a nation's history and the struggle to define a new historical narrative in museums in former colonies is discussed. Watson's description of the permanent exhibits in Hong Kong's Museum of History is similar to the NMS's history galleries. Both museum's 
begin with archaeological artefacts and map a path of progress from pre-colonisation village life to post-colonisation urban street scenes, finishing with modern views of city life. Watson highlights how Hong Kong's Museum of History became a 'political football for local politicians' who confronted a set of identity questions: Are people who live in Hong Kong Chinese, Hong Kongers, Cantonese, Guangdong, cosmopolitans, or something else?' Unlike Hong Kong's Museum of History, however, there has been very little critical analysis of the NMS's history gallery.

In Hue-Tam Ho Tai's account of history displays in Vietnamese museums, she questions whether a single historical narrative does justice to local experience while also illustrating a unified national past. It is a useful essay for this study as some key questions inherent in the concept of national museums also apply to my work, including: 'How is the nation defined? What should be told about its past? Who is included in the story, and how? How does local experience fit into the national narrative?' This essay also maps the development of Vietnam's most important history museums, including the Vietnamese Historical Museum, the Museum of the Revolution and the Museum of the Army. In discussing the Museum of History of Ho Chi Minh City, Hue-Tam Ho Tai highlights the museum's double duty: 'to present both the national past and the southern contribution to that past, highlighting how one must then ask how the museum manages to integrate the two histories, since one is organized along the theme of heroic resistance to foreign conquest, and the other is associated with territorial expansion' (Ho Tai 1998, 187). Ho Tai writes:

The Museum of History of Ho Chi Minh City demonstrates [that] it is not easy to reconcile the local and the national. While the Museum succeeds in presenting the history of the Vietnamese nation as it is understood in Hanoi (and by most lowland Vietnamese), this history excludes all who do not belong to the majority population, whether they be Khmer, Chinese, or members of upland minorities (Ho Tai 1998, 187).

Both Watson and Ho Tai's essays show how Asian national museums share the same challenges with the representation of national histories as western national museums. Given this concentration on western national museums in the literature and the relative dearth of writing about Asian national museums, I believe there is value in exploring a 
contemporary Asian case study and making a comparison with a country like New Zealand, which in many ways may appear quite different. I feel that this gap lends support to my study, which sets out to combine an Asian museum with a museum in a former European settler colony in order to explore transnational and global issues and not simply national ones.

In the 1970s museum professionals and academics began recognizing the difficulties in representing national history in former British colonies, including Australia, Canada and New Zealand, as the communities they represented argued for more socially responsible institutions 'bringing the experience of many people of diverse cultures living together without seeking to eradicate the most recently arrived or least opulently endowed among them' (Kennedy 1996, 65). Mason surveys much of the recent literature surrounding national museums, which focuses on contemporary debates about post-colonialism, first nations and Aboriginal peoples. Such work tends to focus heavily on Australia, Canada, New Zealand and the US (for example, Dean and Rider 2005, Ashley 2005, P. Williams 2005, Simpson 1996). There has been a lot of writing about art, culture and identity in these white post-settler states (Coombes 2006, Message 2006) but more pertinent to this study is the small group of articles that has engaged directly with the internal complexities of developing exhibitions while reconciling political demands for iconic images and stories (McIntyre and Wehner 2001, Healy and Witcomb 2006).

An exception is New Zealand historian Jock Phillips, who was involved with development of Te Papa's Day 1 history exhibitions. He has discussed the role of history in the construction of national identity in national museums in his essays, 'Our History, Our Selves: The Historian and National Identity' (Phillips 1996) and 'The politics of pakeha history in a bicultural museum: Te Papa, the Museum of New Zealand, 1993-98' (Phillips 2001). Relating his experiences of developing these exhibitions to New Zealand's socio-political climate, Phillips discussed the development of history exhibitions in relation to contemporary notions of national identity in New Zealand in the 1990s. Phillips pointed out how history was used to "explore and affirm national identity (for that is what society wants)' in a way that takes account of the 'very genuine concern, 
both intellectual and social, about that notion' (Phillips 1996, 34). He illuminated the realities of developing history exhibitions under the auspices of a government-funded institution, including the problem of:

a Whiggish search for national origins, which artificially plays up certain events and trends and cuts off the sense of surprise and diversity in the past; and it leads to a hunt for large and crude generalizations such as 'national character' which obscure regional, ethnic and class differences (Phillips 1997, 97).

While the 'new museology' is conscious of its own subjectivity or 'constructed-ness,' and may approach questions of nationalism and identity formation with caution, a nationalist agenda remains central in many new museums. The 'new museology' may be 'liberal,' 'enlightened,' 'inclusive,' 'tolerant,' and 'self-conscious,' seeking to 'challenge dominant values and the dominant culture' (Harrison 1993, 47), but it will still construct national identity - albeit a more benevolent vision that seeks to update or challenge older national histories. Indeed, to a degree many of the people involved in the process of remaking national histories in museums are unashamedly cultural nationalists and do not see anything wrong with this. Through a close analysis of both internal processes and external forces at the NMS and Te Papa this dissertation explores how and why museum exhibitions were designed with an agenda of identity formation in mind and how that played out in practice behind the scenes and on the floor. However, it was not part of this study to go on to ask the further question of how visitors responded to specific visions of national identity as part of the museum-going experience, so the emphasis here is on the production rather than the consumption of meaning, and that task falls to another researcher.

\section{National Identity in National Museums}

Amongst the growing literature on museums, galleries and heritage there are a number of articles which reflect explicitly on the relationship between national identities and museums, where national museums feature in broader, historical accounts of nationbuilding (Coombes 1988, Prösler 1996, McLean 1998, Kaplan 2006, Mason 2007). In addition, there are works on nations and museums, although these tend to comprise articles directed at many different historical and geographical contexts (Kaplan 1994, 
Evans and Boswell 1999, Fladmark 2000). Martin Prösler's essay 'Museum and Globalization' (1996) provides a comparative analysis of national museum's relationship with national identity, using historic examples. Prösler links different stages of nationalism and the corresponding types of the national museums which ensue.

As mentioned above, a great deal of writing on national museums has treated the concept of national identity as 'problematic and contentious' (McLean 2007, 329). Yet despite this extensive literature on national identity, Fiona McLean complains that there is 'little real understanding of the ways in which it is contested and negotiated' (McLean 2007, 352). There is little empirical evidence that nationalist ideologies are receding in most parts of the world, despite globalization and current intellectual fashions that aim to deconstruct - and debunk - nationalist ideas (Anderson 1991, Smith 1998). More recently, national museums have become embodiments of their country's identity, visited by those people who wish to see material expressions of the nation's character on display (Davison 2006, 91, Macdonald and Alsford 1989, 3). National museums help to 'define cultural identity and the country itself' (Macdonald and Alsford 1989), stimulate patriotism, and describe those aspects that make it distinct. National museums make positive social contributions by helping to create feelings of pride and worth in the people whose cultures they put on display (McCarthy 2007, Hakiwai 2005, 158), ironically including indigenous people colonized by those very nation states.

The fact is, despite a certain theoretical correctness which drives the enthusiastic project of deconstructing national identity represented in museum displays, that nation states and national museums exist and there is little sign that either is growing less important or, in the case of museums, less patronized in many parts of the world (Mason 2007). In this respect it is important to investigate the link between the national museum and the nationalist ideology that, amongst other social forms, shape the way in which museum practices are conducted. Much has been written about nationalism and the validity of its existence (Anderson 1991, Billig 1995, Connor 2002, Elgnius 2007, Hroch 1996, Zuelow 2007). Nationalism as a concept has slipped in and out of popularity; for a time 'the overwhelming consensus among philosophers was that nationalism was not worth talking 
about' (Poole 1999, 1). Some academics, including Miroslav Hroch, take an abstract view of national identity, claiming that nations are composed of memories of a common past, 'a density of linguistic and cultural ties' (Hroch 1996, 79). While popular definitions uphold the idea that nations are primarily psychological constructions or 'imagined communities' (Anderson 1991, 6-7), others believe nations are more than Benedict Anderson's 'imagined community,' as the nation is 'perpetually re-imagined through an ongoing exchange of ideas' (Zuelow 2007, 158). Benedict Anderson's highly theoretical notion of a psychological construction fails to fully describe the realities of 'nationness'; Anderson concentrates on the moment when a nation is formed and stops there, failing to acknowledge the ongoing nature of the process he describes (Young, Zuelow, Sturm 2007).

This recent strand of writing, which moves beyond static notions of nation as a construct, has been very useful to my study as it allows for the analysis of the ongoing process of constructing, negotiating and updating the nation. Nationhood, in other words, is not merely established, 'it must be maintained'; and its definition, therefore, will inevitably shift over time (Young, Zuelow, Sturm 2007). This is a significant point for it is in the museum, among other places, that nationalism is 'maintained' and where one can see the physical expression and materialisation of national identity. This dissertation shows that national museums are a primary site for the 'maintenance' of national identity, by exploring the complex process of national identity construction through history exhibitions at the NMS and Te Papa.

It is never possible to capture the entirety of the nation, and when national museums actively claim to present the nation as a whole, they are always selective over which element of the nation is deemed appropriate to be celebrated. As Hall points out, national museums which attempt to present the nation holistically are premised on an essentialist belief that the nation exists out there somewhere beyond the museum rather than recognizing the extent to which the museum constructs a historically and culturally specific idea of the nation through representation. What the nation 'means' is an ongoing project, under constant reconstruction. We come to know its meaning partly through the 
objects and artefacts, which have been made to stand for and symbolize its essential values, for as Hall stated 'Its meaning is constructed within, not above or outside representation' (Hall 1991, 14).

I acknowledge the complexities of national identity and the need to avoid too simplistic an understanding of it. National identity 'certainly does not refer to an inward emotion a glow of patriotic awareness - experienced by all who pass by the un-saluted flag' (Billig, 1995). Nor does it mean that everyone within the nation-state becomes identical: as Stuart Hall affirms, 'the notion that identity has to do with people that look the same, feel the same, call themselves the same, is nonsense' (Hall 1991, 49). The construction of a nation's identity relies on 'cultural resources' employed in forming the conception of national community (Poole 1999) which is more than an extended web of relationships between those who share a certain identity. The concept of the nation involves conceptions of the community to which the members of the nation belong (Poole 1999, 6). This identity provides us with a land in which we are at home, a history which is ours, and a privileged access to a vast heritage of culture and creativity.

It is beyond the parameters of this study to engage with all of the debates around nationalism, but the idea that nations are called into being by nationalism, rather than the other way around, resonates most closely with the way that national museums operate. Nations are 'political' artefacts called into being by nationalist ideologies and movements (Jenkins and Sofos 1996, 11). Jenkins and Sofos argue how 'nation' should be conceptualized as 'an unstable' and a 'de-centred' complex of social meanings constantly being transformed by political struggle. The starting point of this dissertation is not whether the 'nation' exists; it is rather 'how the category operates in practice, that is, how nationalist logics and frames of references are formulated and deployed' (Jenkins and Sofos 1996, 11). If nationalist ideas, myths and definitions have to be deconstructed, as stated by museum theorists Day and Suggett, then we need to explore the nation as it has 'figured in successive, and rival, discourses, and consider that question 'How many Wales?' or 'How many ways of being Welsh?' (Day and Suggett 1985, 96). 
In her review of the writing on this topic, Fiona McLean proposes a research agenda in which, through museums, we can 'come to a deeper understanding of identities and notably national identity' (McLean 2007, 352). This research contributes to this agenda by offering focused case studies of particular museum exhibitions in specific locations. From this literature review, I have employed a theoretical framework for this study that allows the research to go some way towards filling the gap in our understanding of how identity creation is negotiated and contested through museum exhibitions. This dissertation argues that it is in the museum, among other public spaces, that conceptions of the community are created and where national identity is shaped and re-shaped for successive generations. Nations and national identity are not static, but instead constantly evolve to meet changing demands. Nations are not strictly maintained through the 'occasional unrolling of a flag or a burst of inflamed rhetoric' (Young, Zuelow, Sturm 2007). Instead, 'older traditions, symbols and memories are constantly altered to serve successive generations' (Young, Zuelow, Sturm 2007).

In the case of national museums, this study seeks to explore how history is constantly reshaped to serve constantly changing societies. Indeed the question we ought to address is not that of the real 'nation' or national identity which lies behind concepts employed in political life, but that of the formation, articulation, and propagation of the concepts themselves. The research therefore not only critically analyses nationalist ideas, myths and definitions by exploring the processes behind the representation of history at the NMS and Te Papa, but through this analysis seeks to understand these ongoing processes as modes of representation in their own right shaped by their time and place.

\section{Methodology: Comparing different approaches to national identity construction}

In this study, an exploration of the theoretical issues in making history and national identity is combined with contemporary case study analysis of colonial history displays at Te Papa and the National Museum of Singapore. Given the factors discussed above about the relative similarities of New Zealand and Singapore as relatively small former British colonial possessions that have struggled to form new independent national identities in the recent past, there is therefore merit in a comparative approach that examines these 
two nations' national museums. The comparative structure of this study, in which the NMS and Te Papa are compared and contrasted throughout, provides a richer analysis of the topic under examination. The centrality of multiculturalism and biculturalism in both countries' nation building projects adds another factor that benefits from a comparative methodology. Although my research explores issues surrounding history and identity at a general level, the museums are used as case studies to explore wider issues in a realworld context. Due to the comparative nature of this dissertation, research was undertaken using the multi-method approach. Qualitative research methods and data analysis were chosen for this study, reflecting the exploratory nature of my enquiry, creating a montage of a variety of empirical data sources that reflect possible multiple representations (Denzin \& Lincoln 1994, 3). A constant comparative method included ongoing data analysis throughout the research period.

The research used both primary and secondary sources. In addition to general secondary sources such as reviews and articles, the analysis of Te Papa's Day 1 history exhibitions employed primary archival sources and exhibition files to gain a sense of the approach curators and other staff took. However, it was not possible to undertake such detailed archival research of the NMS's History Gallery. Interviews with a representative sample of current and former staff at the NMS and Te Papa included the current deputy director of the NMS, Iskander Bin Mydin, and former members of the exhibition team at Te Papa, including Bronwyn Labrum, Jock Phillips and Paul Thompson. The research methods limitations include the inability to research the NMS case study at the same level at Te Papa, resulting in the unequal development of each case study.

A comprehensive 'reading' of key history exhibitions at Te Papa and the National Museum of Singapore included visual analysis of the spaces and layout in which the author observed the style of display, the choice of objects exhibited, the events and personal stories included and any significant exclusions. Visual material such as photographs and floor plans provided an important source from which to reconstruct past displays, including past Te Papa exhibitions On the Sheep's Back and Exhibiting Ourselves. The views of past and current museum professionals provided not only a 
historical view of the past, but insights into past and present museum practice. The variety of data gathering methods for this research resulted in a number of different perspectives on the topics under consideration: policies and historical records were compared with the information gained through interviews with museum staff, which were analysed using the theoretical framework drawn from the literature review. The aim was to gain a wide ranging and critical picture of the exhibitions while not pretending to be comprehensive or exhaustive.

National museums are primary sites for the construction and 'maintenance' of national identity. This is evident in their representation of national history where '... the "past" serves the perceived needs of the present and the interests of current participants ... [And] our vision of 'the past' is shaped by present needs and circumstances' (Smith 1998, 52). To understand how the NMS remakes Singapore and Te Papa reimagines New Zealand we must first understand how these museums arrived at their current state. Chapter one provides some historical background for the NMS's new History Gallery by briefly outlining the history of NMS and its display of history. The ongoing nation-building at the NMS is outlined in this chapter, which not only includes an analysis of the NMS's new History Gallery, but a brief history of past displays, including the old series of dioramas which represented Singaporean history in the Singapore History Museum. In addition the chapter places the recent redevelopment of the NMS, and their construction of national identity, in a broader socio-historical context, which in turn is related to relevant events in the history of Singapore.

Chapter two provides a backdrop to the development of Te Papa by exploring the changing representations and roles of colonial history at the former National Museum. By examining the changing approaches in the interpretation and display of colonial history at the National Museum, including the 1969 Cook Bicentenary exhibition, the establishment of the Colonial History Gallery in the 1970s and 1980s and the infamous mock-period rooms, chapter two establishes a longitudinal approach, along with providing a cultural and historical context for later museological shifts in display practices. Chapter two sets the scene for the development of the Day 1 history exhibitions by critically examining the 
representation of colonial history in the 1992 exhibition Voices He Putahitanga, a precursor to Te Papa's new exhibitions. The 1980s and early 1990s, the period in which Te Papa developed, sees the collision of new perspectives on identity, culture and politics with new museum practices. The chapter demonstrates how the changing attitudes and approaches to the display of New Zealand's colonial history relates more broadly to the changing roles of history exhibitions as tools used to reconstruct national identity. Chapter three, the final in this dissertation, analyses exhibitions Signs of Nation, Passports, On the Sheep's Back and Exhibiting Ourselves in terms of how they present colonial history, and particularly the history of interaction between Māori and Pakeha. Te Papa's diffuse display of New Zealand history, including the separation of cultures and thematic approaches to display, is related to the incorporation of New Zealand's bicultural policies and more general notions of identity in the 1990s.

This comparative study aims to fill some of the gap in the literature of museum studies by providing an Asian case study alongside a post-settler nation in the South Pacific. The research seeks to go beyond the postmodern condemnation of nationalism in museums to understand more fully the persistence and ongoing relevance of national identity and national museums. I intend to explore how museums have proved extremely helpful to young nations because they translate abstract concepts into tangible and quantifiable material evidence. In other words, national museums can be enlisted to provide 'objective proof' for nationalist claims (Mason 2007). This study argues that national museums play an important role in articulating, challenging and responding to public perceptions of a nation's histories, identities, cultures and politics. At the same time, however, national museums are themselves shaped by the nations within which they are located. Using Altman, Zuelow and Poole's theories on nationalism, which argue that nations are 'maintained' through a shared concept of community that is constantly shifting, this dissertation analyses how the concept of the nation is 'maintained' in and relies on the 'cultural resources' of the national museums. While national museums operate as 'space in which it is possible to identify competing definitions of the nation' (Mason 2007, 22), the close examination of history exhibitions reveals evidence of the 'ongoing process of remembering and the remaking of cultural memory in response to the demands of the 
present' (Mason 2007, 22). The research explores how national museums negotiate, on the one hand, the material and intellectual legacy of previous inherited definitions of 'the nation', while on the other responding to the contemporary expectations which arise from present-day conceptualizations of 'the nation' and national identity. This study also attempts to explore national museums' participation in the public articulation and construction of a collective idea of 'the nation' and how these definitions might be unstable, contradictory and contested. 


\section{Chapter 1. United we stand: The History Gallery at the National Museum of Singapore, 2006-2009}

As the Introduction suggested, national museums are 'political arenas', spaces in which definitions of identity and culture are asserted and contested (Karp 1991), and which are inextricably linked with the construction of national identity. In order to appreciate how national museums have arrived at their current form it is helpful to recognize the differences between them, which are the results of different social and political contexts. This chapter provides an Asian example of the national identity constructed through colonial history exhibitions with which to compare with Te Papa. Taking the National Museum of Singapore as its starting point, this chapter shows how a national museum in a former British colony translated and transformed discourses of national culture according to its own disciplinary, intellectual and organizational contexts. As Mason has suggested, this process is a useful way to understand how different museums create the concept of the nation in a distinctive way according to their own situation (Mason 2007).

National identity is unavoidably linked to the processes of colonisation, decolonisation and the gaining of political independence in many countries, including New Zealand and Singapore. In 'the various white constituencies', including Australian, South African, Canadian and New Zealand, national identity is fundamentally 'contingent on the relationship to and with the various indigenous communities they necessarily encountered' (Coombes 2006). In former settler colonies such as Australia and New Zealand, the indigenous communities which were transformed, displaced and marginalised have recently renewed their claims for greater political representation and autonomy. The voices of indigenous communities were crucial in shifting the assumed political authority of earlier and predominantly white settler communities. In other former colonies, including Singapore, Malaysia, and India, the concern with a national past and heritage is more intensely related to the struggle for independence, that is "not so much political as effective independence.... a sense that people are bound as one and have a continuity of shared ideas and sentiments' (Kwok Kian-Woon 1999, 9). 
This chapter explores the redevelopment of the National Museum of Singapore (NMS), showing how the Singapore government's policy objective to promote a strong and inclusive national identity merged with recent international museum practices. On 7 December 2006 the NMS opened after its three-year redevelopment. This redevelopment was consistent with the experience in many other countries where museums have recently embraced new roles and social responsibilities. As I showed in the introduction, this shifting mandate for museums, which has emerged over the last twenty years, was called 'the new museology' (Vergo 1989). The new museology concerned itself with engaging with the public, 'not just during the visit to the museum through interactive displays, but also in the production of their own pasts' (Walsh 1992, 161). During the 1980s and 1990s, in accordance with the tenets of 'the new museology' museums were transformed into democratised sites whose central goal became serving the public (Hudson 2004, 85). The aims of national museums shifted from general public education to the task of symbolising the nation as a whole (Davison 2006, 91; MacDonald and Alsford 1989, 3; Pearce 1992, 118; Phillips 1996, 110).

Given Singapore's short and tumultuous history as an independent state, the Singapore government prioritised cultural projects that encouraged a sense of national identity and social cohesion (Velayutham 2007). The NMS deployed the powerful new resources of the new museology to recreate itself as a more assertive vehicle for Singaporean nationalism, providing a space where Singaporeans could examine their own national past and identity. The NMS's redevelopment provides an example of how a museum was harnessed for a state-sponsored process of nation building. Rather than just interrogating its 'symbolic and governmental function' (Crampton 2003, 221), this chapter analyses the ideological roles of the NMS at the same time as addressing the specific content of the exhibitions. In exploring how meaning was generated, this study acknowledges how 'spatial orderings, classification, and museum discourses reproduce dominant structures of knowledge' (Crampton 2003, 221). The analysis of the new History Gallery also shows how Singapore's political ideals of multiculturalism were used as 'focal points' for the construction and promotion of an inclusive national identity. 


\section{The History of Singapore}

The redeveloped history exhibitions provided the NMS and government of Singapore with a potent new medium with which to advance a 'soft nationalist' agenda (Velayutham 2007), encouraging a sense of belonging to and connection with a national historical experience - a national identity - alongside the island's more deeply ingrained ethnic identities. But before we examine the NMS itself in some detail, we need to look at the history of this island nation and its various and changing identity over time. The Singaporean nationalist project to unify and provide economic security to a diverse population within a small and tenuous political territory has not changed radically since the state's inception in 1965. What has changed is the way in which the Singaporean government has deployed the past, history and memory to support nationalism.

At first the colonial period seemed more of a burden than crucial glue that could help hold a national identity together. Senior Minister S Rajaratnam explained the 'necessity' of a collective denial of Singapore's colonial past:

Most of the 170 years history following Raffles' purchase of this island for a few thousand Mexican dollars is not something that Singaporeans like to proclaim from the housetops, because all that history was British colonial history. The only proven history Singapore has was in the eyes of most nationalists a shameful episode of exploitation, oppression and humiliation of a people who nevertheless insisted on remaining in Singapore. Patriotism required that we performed some sort of collective lobotomy to wipe out all traces of 146 years of shame. (Rajaratnam 1972)

In time, however, Singaporean leaders found the colonial period an essential foundation for the new national identity because Raffles' Singapore lumped subjected ethnicities together in one place that matched the modern territorial limits established in 1965. Singapore of 1819 conveniently amputated the island from its chaotic pre-colonial history and thereby also from the Sultanates of the Malay Archipelago and other colonial entities. Minister Rajaratnam explained how the notion of a post-1819 Singapore could bypass an uncomfortable intra-Asian history of civilisational rivalry:

We could have contrived a more lengthy and eye-boggling lineage by tracing our ancestry back to the lands from which our forefathers emigrated - China, India, Sri Lanka, the Middle East and Indonesia. 
The price we would have to pay for this more impressive genealogical table would be to turn Singapore into a bloody battleground for endless racial and communal conflicts and interventionist politics by the more powerful and bigger nations from which Singapore had emigrated.

So from our point of view, to push a Singapore historical awareness beyond 1819 would have been a misuse of history; to plunge Singapore into the kind of genocidal madness that racial, communal and religious imperialism is today devastating so many underdeveloped and even developed countries. The present government, much to the dismay of local racial and cultural chauvinists, has been careful about the kind of awareness of the past it should inculcate in a multicultural society. (Rajaratnam 1972)

Eschewing a racialised identity, Singapore constructed a national identity largely based on promoting the notions of economic and social development within a unified and harmonious multicultural state. The arrival of Sir Stamford Raffles in 1819 marked the start of the colonial moment, a convenient beginning for a story about economic and social progress:

the establishment of Singapore as an entrêpot with free-port status; the building of a modern city and other infrastructures; the creation of governmental institutions, civil and legal services; the provision of education and medical services ... (Velayutham 2007, 23)

Singapore's pre-colonial history went unrecognised as the nation's history and identity were presented as being inseparable from the colonial moment. The colonial moment privileged a "'transition narrative" - seeing Singapore move from obscurity to prominence, an ancient period to modernity, fragmented to unified' (Chakrabarty 1992, 339). The NMS shows important aspects of Singapore's national identity including the significance of economic development within a harmonious multicultural state as having originated in Singapore's colonial past. Pre-colonial Singapore and pre-modern history are largely disregarded, as Singapore's history is 'entrenched in the discourse of colonialism and the arrival of Western modernity' (Velayutham 2007, 22).

However, Singapore's history can be traced back to the Malay entrepôts of Srivijay and Melaka, an outpost of the Sumatran Srivijaya empire. Singapore was originally known by its Javanese name Temasek ('sea town') (Turnbull 1989) and rapidly became a significant trading settlement, controlled briefly by the Portuguese and then by the Dutch 
in the $17^{\text {th }}$ century. When Sir Stamford Raffles arrived in Singapore on 28 January 1819 , Singapore was already a well-established part of the Asian maritime economy, and extremely multicultural. Although the history of Singapore up to 1819 was 'largely a Malay history’ (Velayutham 2007, 21), Thai, Javanese, Portuguese, Dutch and British also featured. Moreover, the people who 'left their mark on the ancient history were Chinese, Malays, Indians and others, who were essentially of the same ethnic stock as the people who constitute the racial mix in the Singapore nation of today' (Lee 1986, 1). However, it was the colonial moment, and the foundation of Singapore as a discreet political entity, which allowed the possibility for the articulation of a 'single and unified sense of place despite the different and diverse histories of its immigrant population' (Velayutham 2007, 22). Through its representation of the colonial period, the NMS could therefore unify their population, represented within a single historical process and place.

Prior to the NMS's redevelopment, Singapore's history was retold in a series of dioramas chronologically charting Singapore's progress, while reducing Singapore's history to official moments reflected in scenes including Diorama 3: Arrival of Stamford Raffles to establish a Trading Port, 29 January 1819, Diorama 4: Chinese Junk Trading Season, 1820s, Diorama 5: Bugis Trading Season 1830s, Diorama 7: Commercial Square 1850s, Diorama 8: Construction of Government House by Convict Labour, 1860s, and Diorama 14: Official Opening of Naval Base Dock, 14 February 1938. The dioramas highlighted Singapore's commercial heritage, as the history of growth and development is reflected in scenes of construction. The display of dioramas also accentuated the significance of the British in Singapore's colonial history, with only two dioramas of Singapore prior to Raffles' arrival. Diorama 2: Singapore Before Raffles, 1818 depicted a team of fishing boats and Diorama 1: Ruins of Ancient Settlement at Fort Canning, 1823 depicted a white colonial official surrounded by local Malay men dressed in loin cloths inspecting artefacts found on Fort Canning Hill. In contrast, the new History Gallery devotes a large space, known as the Temasek Gallery, to the representation of pre-Raffles Singapore. A short film, Seraja Singapoura: Picture of 14th Century Singapore screens in a room off the Temasek Gallery. The film 'proposes several hypotheses on the origins of Temasek's first inhabitants and rulers' (Lenzi 2007, 56). In the Temasek Gallery, 14th-century 
artefacts, including gold ornaments, Chinese porcelain and glass found on Fort Canning Hill, are displayed in front of a large background image of an unpopulated and lush tropical island.

\section{The National Museum of Singapore}

The National Museum of Singapore, like New Zealand's Colonial Museum, modelled itself on nineteenth-century museums elsewhere in the British Empire. These were institutions with 'overpowering cultural authority... [expressing] ambitious and encyclopaedic claims to knowledge' (Karp and Kratz 1991, 23-25). During the nineteenth century, museums positioned themselves 'as purveyors of objective truth' through their emphasis on the "scientific nature of knowledge produced in the classification and organisation of their collections' (Coombes 2004, 242). At the time when what was known as the Raffles' Museum opened in 1887, it was considered that the museum's function in society was first and foremost ideological: through its structure and content, its role was to inculcate 'society's most revered beliefs and values' (Duncan \& Wallach 2004, 52). Nineteenth-century museums also served political ambitions by 'convincing the working classes that their interests were best served by the development and expansion of empire' (Coombes 1991, 203). The opening of museums was important for the state in 'producing national subjects and fostering a nationally unified support for imperial policies' (Crampton 2003, 220).

Harrison argues that the museum had 'nineteenth-century scholarly and entertainment roots' (Harrison 1993, 39). The Raffles Museum's links to this general aim are highlighted in Governor Sir Frederick Weld's speech at the opening of the museum in 1887 :

The museum and library should be on a scale commensurate with the gathering importance of the colony and that whilst our museum should be rendered a place of amusing and instructing resort, it should also ultimately possess a staff competent to render service in science and industrial knowledge and devoted to the development of these settlements and states. (Weld 1887)

Following nineteenth-century museum practices, the Raffles Museum established an extensive collection of zoological specimens. Their display educated the public, and 
informed experts through its classification and descriptions of South-East Asian flora and fauna. In 1895, Raffles Museum Director Dr Hanitsch led the first ever expedition to the Singapore Islands of Pulau Brani and Pulau Blakang Mati (Raffles Museum of Biodiversity Research, 2009, rmbr.nus.edu.sg) and in the early twentieth century British curators at the Raffles Museum began actively contributing to building up the collection by organising expeditions to various parts of South-East Asia (Raffles Museum of Biodiversity Research, 2009, rmbr.nus.edu.sg). One of the Museum's most iconic displays, a blue whale skeleton, was first exhibited on Chinese New Year's Day 1907 (Lenzi 2007, 15). Visitors were filled with awe on viewing the skeleton suspended from the ceiling, enormous articulated elephant skeletons (Lenzi 2007, 15) and cabinets full of zoological specimens which lined the gallery walls. However, it was not to last. The fate of the NMS's superior natural history collection emphasises the NMS's drive to construct and promote national identity in the post-independence 1960s and 1970s.

During the 1970s the NMS began pre-empting aspects of the new museology by exploring and questioning underlying attitudes behind museum collections and display. This was common in museums elsewhere, as Harrison shows (Harrison 2005, 39). Although museums had traditionally been closely associated with helping to promote the state's power and prestige, curators increasingly argued that museums should address their social responsibilities rather than continue 'collecting, documenting, preserving, exhibiting and interpreting objects' (Harrison 2005, 43). Inevitably museums had to decide whether they were to be 'object- or people-oriented and whether they were research institutions, or whether they were there to serve the public through educational programmes' (Harrison 2005, 41). Following Independence in 1965 the Raffles Museum was renamed the National Museum, reflecting its new pivotal role in nation building. The NMS became a 'key repository of the new nation's cultural heritage' (Lenzi 2007, 16), taking on an 'official nation-building role' $(2007,16)$. In 1972 the NMS, in an attempt to discard its reputation as a centre for scientific research, transferred its substantial natural history collection to the National Museum of Malaysia, attempting to refocus and 'shed its Victorian identity as a vocationally-mixed institution' (Lenzi 2007, 17). Increasingly 
the NMS began to focus on representing the nation's history, and by 1984 the museum included a History of Singapore Gallery.

In the early 1990s the Singapore National Heritage Board, established in 1993, began rethinking the role of the NMS. Singapore's national collection of local painting, archaeological wares, Chinese and South-East Asian ethnographic material, and historical documents relating to Singapore's colonial past could not be managed or housed by one institution (Lenzi 2007, 17). The National Heritage Board, in an effort to redefine the roles of each institutions, split the holdings into three distinct bodies, creating three different museums based on the collections (Lenzi 2007, 17); The Asian Civilisation Museum, the Singapore Art Museum and the Singapore History Museum. The collection of artworks, papers and objects providing material evidence of Singapore's pre-modern, colonial and post-Independence past was displayed in the Singapore History Museum, in the original Stamford Road building (Lenzi 2007, 17). However, as the Asian Civilisation Museum increasingly positioned itself as the dominant history museum with arguably richer collections and displays, the Singapore History Museum had to reposition itself. In 2003 the Singapore History Museum closed for re-development. In 2006 the NMS reopened, with a new name signaling itself as the primary site for the articulation of national identity.

The NMS is governed by the National Heritage Board, which consists of a statutory board and under the aegis of the Ministry of Information and the Arts (MITA); 'its role and activities span managerial, executive, consultative and guiding functions' (Tan Peng Hong 1999, 114). The NHB's mission is to 'explore and present the heritage and nationhood of the people of Singapore in context of their ancestral cultures, their links with South-East Asia, Asia and the world through the collection, preservation, interpretation and display of objects and records' (NHB Annual Report 1995/96). The mission statement emphasises an 'explanatory, inclusive approach toward Singapore heritage'. This approach is 'contextualised not merely in the local setting but in a regional and global setting' (Tan Peng Hong 1999, 114). Operating under Singapore's National Heritage Board (NHB), the NMS aims to foster a multicultural nation with a history of 
severe inter-ethnic violence. National efforts to recall a shared past are necessary as part of an attempt to construct national myths and identities as well as 'national loyalties' (Kwok Kian-Woon 1999, 9).

\section{The History Gallery}

The NMS's History Gallery comprises eight distinct zones, taking the visitor from the landing of Sir Stamford Raffles in Singapore in 1819 and the island's subsequent colonial settlement by the British, right through World War II to self-government, union with and separation from Malaysia and, finally, the trials and economic development of the postIndependence period (Lenzi 2007, 52). Entitled Arriving, Settlement, Emporium, Portcity, Modern Times, Fortress and Syonan-to, Merdeka (independence) and New Nation, these thematic sections aim to 'cover every aspect of Singapore's transformation from commercial outpost to migrant colony to independent developed nation' (Lenzi 2007, 62). Entering the History Gallery, the visitor can choose between the Events Path, which presents a political history that deals with kings, ministers, battlers and treaties with nation-states and their mutual relations, or the Personal Path, which concentrates on aspects of Singapore's social history:

those keen on exploring its major headline events do so via the Events Path, while those interested in the effect of the same history on the man on the street elect the Personal Path (Lenzi 2007, 61).

The History Gallery portrays a chronological, progressive history of Singapore in which the colonial period is a 'foundation moment' and the genesis of multiculturalism.

NMS's incorporation of new technologies in which the visitor can 'experience' history is part of 'new museums' growing social responsibilities, including 'social re-definition' and 'cultural empowerment' as well as providing entertainment (Harrison 2005). The History Gallery provided the visitor with the aid of an AV device called the Companion. With the Companion, the visitor follows the pathways, entering film set-like spaces that tell the stories of different characters or events from Singapore's past. The visitor 'actively chooses his own path through the gallery' (Lenzi 2007, 52), which provides a 'lively and interactive' experience 'of the many aspects of Singapore history he wishes to 
explore' (Lenzi 2007, 52). The spaces are contextualized with relevant artefacts, videos, films and ambient lighting so as 'to create or to engage a sense of intimacy between visitor, story, and space' (Bin Mydin 2008). A numbering system is used whereby the visitor can press a number on the Companion screen according to the number indicated on the floor of the story space and thereby have access to the stories and factual information. The Companion contains narrated stories, minimal exhibit text, artefact captions, and archival film footage, which allows the visitor to draw their own conclusions about history. Avoiding the singular authoritative voice, the Companion also includes recordings of interviews with academics and experts on the historical events and figures. Iskander Bin Mydin the senior curator of history at The National Museum of Singapore took a 'story-telling approach to Singapore history, situating it in film-like sets' (Bin Mydin 2008).

\section{'The New Museology': multiple viewpoints and social history}

In the History Gallery the tenets of 'the new museology' mixed with the desire to construct national identity, resulting in the NMS's inclusive display of a history of progress. The History Gallery's more socially inclusive national history included the lives of poor immigrant labourers and women alongside the national heroes from each of the main ethnicities. The more inclusive representation of the national story contrasts the anonymous plasticine men in the Singapore History Museum's dioramas.

According to senior curator Iskander Bin Mydin, the National Museum of Singapore's understanding of how to represent Singapore's history in a museum setting was based on 'having an approach that provides space for multiple perspectives on Singapore's history, and in doing so, to shift from the overarching or master-narrative of the "Singapore Story”' (Bin Mydin 2008). Engaging with 'the new museology' the History Gallery provided different and opposing viewpoints in an attempt to provide a 'balanced and open historical approach to events and personalities from Chinese, Malay, Eurasian, European, Indian and Middle Eastern communities' (Lenzi 2007, 62). An example of this is the 'conflicting British and Dutch claim over Singapore in the period following Raffles' landing evoked in an audio presentation inspired by the original letters sent during 'the 
wrangling by Raffles and the Dutch Governor-General of Java, Baron Godert Aelxander van der Capellen, to their respective government in London and The Hague' (Lenzi 2007, $62)$.

The NMS also sought to broaden historical information about the regional and sometimes international repercussions derived from incidents that were based in Singapore. Through the Companion's section Singapore and the World, visitors to the History Gallery were provided with access to information, including interviews with academics about Singapore's relationship with the world at different points in history. The Companion presentation related to the World War II Fortress 1941-1942 followed by Syonan-to 1942-1945 zones included a short interview with two local Indian women recruited as teenagers to serve in the Indian National Army (INA) (Lenzi 2007, 67). The women speak about their experiences as volunteers for the INA in Singapore during the Japanese Occupation, and were led on a march through Malaya, Thailand and Burma, aiming to reach India (Lenzi 2007, 67). Through the inclusion of women's history the NMS's engaged with the tenets of the new museology that prescribed greater social inclusion.

Adopting greater levels of inclusiveness extended to re-telling histories, incorporating the stories of those who had long been excluded, including indigenous communities, women and children. The new History Gallery addressed the lives of women living in colonial Singapore in spaces the Women's Corner, which included the exhibits Amahs [fig 2] and Mems and Their Servant's. Opposite the Women's Corner in the History Gallery is a room dedicated to the charity worker May Wong or Auntie May [fig 1]. The visitor listens to an oral history interview with May Wong, while at the same time viewing Auntie May's personal objects, including her Cheongsam, a dress fusing Chinese and Western style, a bonnet, shoes, trinket box and samples of embroidery. Aunty May was a wealthy woman. However, the History Gallery was mindful to include the history of Singaporean women from different cultures and social strata, including the stories of Chinese Amahs, Japanese prostitutes and Sophia Blackmore, an Australian missionary who established Singapore's Methodist's Girls School (Turnbull 1989). 
The History Gallery merges the history of different migrant groups, within the broader history of Singapore's economic development. In the centre of the colonial history space sits the largest artefact on display, Tam Jiak Kim's funeral hearse. Tan Jiak Kim was a prominent Pernakan industrialist, founder of the Straits Steamship Company Ltd, and member of the colonial Legislative Council (Lenzi 2007, 64). The Millionaire's Funeral Hearse is a symbol of the Peranakan (Straits Chinese) community's economic success. The hearse dominates both Emporium: 1820s-1860s and Port-city: 1870s-1900 spaces and is surrounded by objects representing other ethnic groups, including the poor migrant worker, represented by a Chinese rickshaw [fig 3]. The NMS included the stories of poor migrant workers in the history of Singapore's economic development. The migrant worker, often referred to as a 'coolie', is also subtly represented by the display of a selection of bricks [fig 4]. Each brick sits on a plinth in front of an original photograph of the large colonial public building, reflecting the plight of the manual labourer and the practical work required to build colonial Singapore. Using elements of social history, the History Gallery included darker aspects of Singapore's colonial past, including the history of opium dens and stories of Karayuki-san, Japanese women who travelled to South-East Asia in the second half of the 19th century to work as prostitutes. By exposing the appalling, everyday degradation of Singapore's rank and file migrants - Chinese, Malay, and Indian - the museum used social history to connect the majority of today's citizens with their own shared heritage.

In the space titled Chasing the Dragon the NMS recreated a mock opium den from the nineteenth century [fig 5]. The NMS created an ominous and menacing atmosphere through the construction of a darkly lit space with red lanterns hanging from the ceiling. Inside the mock opium den the visitor experienced the plight of Chinese coolies who frequented the dens, becoming addicted to the narcotic in an attempt to escape the harsh realities of their lives as manual labourers (Thulaja 2002). There is an original wooden opium 'bed' which smokers lay on [fig 6], along with glass cabinets full of original opium-smoking paraphernalia. Under the printed text panel declaring 'Here they forget' are a series of haunting photographs of Chinese opium smokers in Singapore. The NMS used small spaces in which historic scenes are recreated so the visitor experiences the 
sensation of stepping through the glass and into the traditionally sealed off mock period room or diorama. 'As if walking through a story' the film-set like rooms let the visitor understand history 'on many levels and from various angles, leaving the museum...with a sense of having experienced history's texture and meaning' (Lenzi 2007, p. 52).

\section{The Hall of Fame}

One of the primary roles of a national museum is to provide the nation with an 'origin' story and an account of its forebears (Prösler, 1996). In the History Gallery important personalities from the colonial past, including business men and administrators, are used to emphasise Singapore's history of economic development and progress. A portrait of Raffles painted in 1817 by British artist George Francis Joseph was hung at the entrance of the gallery, representing the landing of Sir Stamford Raffles in Singapore in 1819 and signalling the beginning of the colonial period in the History Gallery. Below the painting of Raffles, in a glass case, lays an original letter written by Raffles in 1823 during his last visit to the island. The NMS highlighted how Raffles' letter describes Singapore as a 'booming entrêpot' (Lenzi 2007, 62). The colonial period is represented as a time when Singapore established itself as a significant commercial place of trade, The NMS interwove important historical figures from Singapore's colonial period with the story of Singapore's economic and social development.

The new History Gallery took a 'hall of fame approach' in the representation of key figures from Singapore's colonial history. Using national heroes as an ingredient to instil as sense of pride and achievement in the past, as in all countries, inspirational identities stare out from banknotes, stamps, and school textbooks. In the Events Path of the new History Gallery, the stories of key political and social figures from each of the main ethnic groups are retold in mock period rooms, in which all major ethnicities get a stake. The stories of significant men - English, Chinese, Malay and Indian - are infused within the progressive 'history of winners' (Schlereth in Carbonell, 335), including key founders, businessmen, politicians and spiritual leaders. The History Gallery retold the histories of influential men such as Sultan Hussein, the seventeenth Sultan of Johor who allowed a British settlement in Singapore, and Munshi Abdullah, who wrote extensively 
about early Malay history and acted as a translator and teacher to colonial officials.

Munshi Abdullah is represented through the display of his original last will and testament, written in 1854 , which is displayed in room fitted out like a traditional Malay village building with woven fibre walls and teak joinery [fig 7].

The story of one of Singapore's most prominent traders and philanthropists of the colonial period, Tan Tock Seng, is retold in a room in which Thian Hock Keng temple is re-created (Lenzi 2007, p. 61). Incense, candles and religious icons are displayed in front of a large colour copy of a historic temple scene that acts as a backdrop. This dark, almost mystical space contrasts dramatically with the rooms in which the lives of British colonialists are retold. The NMS's History Gallery accentuated colonial Singapore's ethnic diversity. Using various stylistic techniques that included lighting, props and colour, the History Gallery emphasised cultural differences.

\section{Farquhar and Read}

The room parallel to the Raffle's display is devoted to the display of several natural history drawings from the collection of William Farquhar, first British Resident of Singapore (1819-1923) [fig 8]. The drawings, hung from floor to ceiling, include delicately rendered images of tropical plants, monkeys, fish and birds executed by anonymous Chinese artists in Malacca (Lenzi 2007). Farquhar's brightly lit space, with its neatly hung drawings and uncluttered space, appears to accentuate the state of order British colonialists hoped to enforce on Singapore.

Directly opposite Farquhar's space is a room addressing William Read, a British politician who devoted much of his career to developing Singapore [fig 9]. Read's status as a colonial gentleman is emphasised in the small formal room, faux-Georgian in design. Inside Read's sparsely decorated, white room hangs a series of original paintings of Singapore in the nineteenth century. The paintings are idealised, European images of Victorian settler's enjoying daily life in the Orient. One painting depicts European settlers sitting in horse-drawn carriages and playing cricket on the grass while dark-skinned men are painted walking on their hands and knees. These paintings flank a life size oil portrait 
of William Read, the focal point of the room. The Portrait of William Read, 1888 is a sombre image of an old man whose interest in state affairs is reflected through the depiction of a large office desk with documents strewn over it. His career in South-East Asia is hinted at with the depiction of tropical foliage peeking round the corners of large wooden louvered windows.

The Portrait of William Read is a far less grandiose image than John Singer Sargent's Portrait of Sir Frank Swettenham, 1904 [fig 11], which hangs at the exit of the colonial history space. Sargent represents Swettenham as the archetypical colonial ruler, surrounded by symbols of power including a globe, his army uniform with medals, maps and a throne-like chair. His power is reflected in his regal stance, as he leans against a piece of finely woven South-East Asian brocade. The Portrait of Sir Frank Swettenham is flanked by two equally imposing oil paintings Portrait of Sir Shenton Thomas [fig 12], a British Governor of Singapore, painted by renowned Chinese artist Xu Beihong in 1939, and Portrait of Sir Cecil Clementi Smith [fig 10]. The Governor's stiff posture depicted in the Portrait of Sir Shenton Thomas, is Xu's attempt to capture the tension created by the imminence of war, as the wall of imposing male colonialists not only symbolises the pinnacle of the colonial moment but the end of the empire.

Indeed, the next section of the History Gallery is titled Fortress 1941-1942 followed by Syonan-to 1942-1945 and represents Singapore's attempted defence of the island and eventual surrender to the Japanese. The sections dealing with World War II provide the NMS with a springboard from which to accentuate Singapore's post-war development into a prosperous nation. The spaces dealing with Singapore's colonial history establish the nation as an important place of nineteenth-century trade, and act as a forerunner to the final sections of the history gallery charting Singapore's development under Lee Kuan Yew. These later sections of the History Gallery highlight the progressive themes: Building the Nation, Industrialising the Nation, Eye on the Konfrontasi, Getting Organised, Making an Army, Prosperity Achieved and The Singapore Girl, and allegedly represent Singapore's complex modern history from multiple and sometimes 'conflicting anti-establishment' viewpoints (Lenzi 2007, 68). 


\section{Multiculturalism}

Like other national museums such as the Canadian Museum of Civilization, the redevelopment of the NMS reflects Singapore's ongoing socio-historical contexts, drawing out or concealing moments in Singapore's history, depending on national requirements (Archibald 2007, 60), which include the construction of national identity. Central to the NMS's construction of national identity was the promotion of multiculturalism. The History Gallery highlights aspects of Singapore's colonial past, crucial to the vision of a harmonious multicultural state, including the arrival of immigrants, and the formation of Singapore as a significant global place of trade and commerce. Bin Mydin acknowledged that colonial history was an important component of Singapore's history 'in terms of the development of Singapore in historical perspective' (Bin Mydin 2008). The colonial period is tied to the rise and development of Singapore for much of the nineteenth century and 'for its legacy of administration, law, and immigration policies' (Bin Mydin 2008). The NMS formed and maintained national cultural consciousness by creating unity within diversity (Haas 2003, 5; MacDonald \& Alsford 1992, 310) as the Singapore leaders aimed to promote a sense of commitment to the state in the various race groups and instil racial harmony (Chan and Evers 1978, p.123). The History Gallery represented each ethnic group, and provided multiple viewpoints in the retelling of history. It encouraged 'argument, dialogue and conversation’ (Postman 1990, 58) while; ‘...covering every aspect of Singapore’s transformation from commercial outpost to migrant colony to independent developed nation.' (Lenzi 2007, 62)

Singapore's progressive retelling of history leads to a final and singular vision of the prosperous state in the sections poignantly titled Prosperity Achieved and The Singapore Girl, which addressed the success of Singapore Airlines. The final space titled August $9^{\text {th }}$, addressed Singapore's National Day with a large video projection of the National Day Parade. The history of the previous galleries are like stages leading to the ultimate confirmation of Singaporean national identity, the National Day Parade. 
Both the National Museum of Singapore and Te Papa redeveloped during periods in which national museums became 'theatres for the renegotiation of the national histories they showcase' (Thomas 2001, 304). The NMS's redevelopment, like other museums around the world, matched new curatorial trends, aligning itself with the contemporary leisure and entertainment industry (Cannon-Brookes 1991, 351). The redevelopment of the NMS also included adopting aspects of the new museology, to 'create a national vision from the nation's component parts' (Prystup 2001, 52). Through its use of art, technology and popular culture the NMS aimed to present 'the complexities of the country's past and the layered, multicultural identity of its people' (Lenzi 2007, 46). The History Gallery, like other new museums elsewhere, reflects 'experiential and participatory' goals over the display of 'dense artefactual exhibits and curatoriallydetermined content' (Harrison 2005, 45).

This chapter shows how the NMS reinterpreted Singapore's colonial past, a period which posed challenges. Even with Singapore's joining of the British Straits Settlement and its establishment as a crown colony in 1826 (Velayutham 2007, 22), colonial Singapore was a socially and ethnically fragmented, immigrant society. The NMS re-imagined the colonial period, slotting it into a larger national story of economic and social progress. The History Gallery retold a history of social, political, and economic history, beneath the umbrella of multiculturalism. The overt Singaporean national identity conveyed here is all about harmony and a way of diffusing ethnic tension. In the NMS's History Gallery all major ethnicities get a stake; freedom to be Indian or Chinese is being Singaporean. In the next chapter, we turn to consider New Zealand's national museum and how it questioned what it meant to be a New Zealander. 
Chapter 2. New wine in old bottles: The new museology and colonial history at the Museum of New Zealand, 1980s-1990s

This dissertation explores the relationship between history exhibitions at the National Museum of Singapore and Te Papa and the construction of national identity. The previous chapter explained how the NMS used a chronological and progressive history of Singapore to represent the colonial past as the genesis of modern Singapore, establishing the key aspects of Singapore national identity, namely economic development and harmonious multiculturalism. In this chapter we examine the new national museum of New Zealand and how its history exhibitions were related to the very different nationbuilding project in this former settler colony in the South Pacific.

An awareness of why state agencies create national museums to conform to specific codes and theories, and the impact museums have on the representation of history and the construction of national identity, provides insights into the potential development of the institutions themselves and the populations they represent. Successive governments developed the concept of the Museum of New Zealand Te Papa Tongarewa during the 1980s and 1990s - an era when constructing a sense of national identity was a key objective, evident in the representation of national history in various forms. The analysis of the forging of national identity at Te Papa, which opened in 1998, demonstrates how the notion of national identity shapes and is shaped by history exhibitions.

Te Papa's history exhibitions were a product of their time, and Te Papa's construction of New Zealand's national identity was part of an ongoing and complex process. This chapter provides a historical backdrop for the redevelopment of Te Papa, including the integration of the former National Art Gallery and National Museum, the introduction of new bicultural policies, the resurgence of Māori culture, and the conception of the Day 1 exhibitions. The construction of national identity in Te Papa's Day 1 exhibitions does not occur in isolation; rather it is the outcome of a complex set of processes and policy decisions reaching back several years. 
Te Papa was redeveloped at a time when new perspectives on identity, culture and politics collided with new museum practices. By situating Te Papa's new history exhibitions in relation to national identity formation, this study contributes to a deeper understanding of the contestation, negotiation, adaptation and maintenance of this complex process. This chapter briefly outlines the development of colonial history exhibitions at Te Papa's predecessors, the Dominion and National Museum, providing a background for the re-imagining of colonial history in exhibitions of the 1980s and 1990s. Practical examples of how national identity was 'maintained' in earlier conceptions of national identity are discussed by analysing the display of colonial history in the National Museum's Colonial History Gallery. A general historical overview of the earlier representation of colonial history at the National Museum precedes a more detailed analysis of the exhibition Voices He Putahitanga, a precursor to Te Papa's Day 1 history exhibitions.

\section{Colonial History exhibitions at the National Museum}

From the 1980s, museums in New Zealand struggled to reinterpret the colonial past for new times. But a Pākehā interest in their own past, while relatively recent, had its origins in the late nineteenth and early twentieth century in popular expressions of interest in settler objects, stories and places. As early as 1897 an interest in colonial history in New Zealand was evident as steps were taken to preserve Captain Cook's landing spot in Queen Charlotte Sound (McLean 2000, 24). The honouring of early European events, such as Cook's landing and the arrival of settlers, marked the first phase of interest in New Zealand's colonial history. However, the push to construct national identity was not synonymous with the formulation of settler identities. New Zealand historian Gavin McLean identifies a number of 'first phase' actions to recognize New Zealand's colonial history, such as Dunedin's 1898 jubilee during which the Otago Early Settler's Association, ‘which set up New Zealand's first social history museum', was established (McLean 2000, 27). New Zealand was anxious to have a history its own, separate from the Mother Country. The process of national myth-making occurred as historic sites started being preserved and events were commemorated, including Cook's Landing at Ship's Cove (McLean 2000, 27). An early attempt at national myth-making included the 
conception of 'Māoriland' (McLean 2000, 27). According to McLean 'European artists and intellectuals tended to lump Māori with the flora and fauna' (McLean 2000, 24). The conception of 'Māoriland' was also an early attempt at constructing a sense of settler identity. These early attempts to celebrate and preserve New Zealand's colonial history honoured European pioneers, and were 'stepping stones toward the construction of a local literary culture and a sense of national identity' (Phillips in McLean 2000, 24).

In 1865 the Colonial Museum (predecessor to the Dominion Museum, National Museum and, later still ,Te Papa) opened under the directorship of James Hector. The function of the museum, under Hector's leadership, is evident in a memorandum:

One of the most important duties in connection with the geological survey of a new country is the formation of a scientific museum, the principal object of which is to facilitate the classification and comparison of the specimens collected in different localities during the progress of the survey'.

Hector was a scientist who specialised in geology (Dell 1965, 10). Under his leadership the Colonial Museum 'like the colonial project explored, described and classified the country' (McCarthy 2007, 16). This was part of a broader, empire-wide development. In Singapore, the Raffles Library and Museum opened on Stamford Road (Lenzi 2007, 12) in 1887, and like New Zealand's Colonial Museum it was a 'repository for artefacts including flora, fauna and people of the region' $(2007,12)$. Similar institutions sprung up not just around the British Empire, but also in other European colonial territories as well as in independent countries such as the United States and Argentina. Early photographs of the interior of the Colonial Museum, renamed the Dominion Museum in 1913, reveal galleries cluttered with natural history specimens and Māori ethnographic 'curios' and 'specimens' (McCarthy 2007, 19). Up to the 1920s the Dominion Museum, like the Raffles Library and Museum and other national museums of the period, were primarily research- and collection-based institutions. Indeed, the collecting, research and display of Māori artefacts and New Zealand's natural history, including zoology, botany and geology, dominated the first half of the century.

By the 1960s, however, the Dominion Museum began to recognise how 'interest in the early days of European settlement was growing fast' (Annual Report 1969, 21), together 
with an interest in household objects and furniture used by early settlers $(1969,21)$. The Dominion Museum's Annual Report from 1967 stated:

colonial history had been accepted as a proper field for the Museum to enter, and it was hoped a staff member would be appointed for this department as soon as possible. (Annual Report 1967)

Mr Millar was appointed curator of colonial history in 1968, to coincide with the development of a Captain Cook display for the bicentennial celebrations of 1969. Millar had a specialist interest in the colonial period and wrote a series of features for the newspaper. In his article 'Photos from the Past' he addressed photographs of Wellington scenes taken between 1865 and 1905 (Annual Report 1969, 21). Although there was a large collection of objects representative of New Zealand's colonial history, including relics of early whaling days, the Elgar Bequest, a series of ship models, period costume and textile collection, firearms and technology, these objects were yet to be contextualized in an exhibition on New Zealand history. Uncertainty about representing colonial history prevailed at the Dominion Museum through the 1960s - 'In developing a section such as Colonial History it is difficult to lay down a framework' (Annual Report 1969 , p. 21) - and the growing interest in New Zealand's colonial history was yet to be included in the national museum's conscious construction of national identity.

The Cook exhibition of 1969 was one of the Dominion Museum's early attempts at conscious construction of national identity through the use of colonial history. The exhibition, prepared by the National Publicity Studios and the former National Museum, was approved by the Government as part of the official national New Zealand celebrations for the Cook Bicentenary (Annual Report 1969). The exhibition can be read as part of the State's conscious construction of a national identity for 1960s New Zealand. The first part of the exhibition included a series of panels showing the state of knowledge of the world in 1768, and the instruments available for navigation. It then traces Cook's early career, showing the structure of the Endeavour and the supplies that went with her (Annual Report 1970). The exhibition also included cannon from the Endeavour, a gift from the Australian government, and a model of the Endeavour gifted by the British 
government. A mock period room of Cook's cabin included mannequins dressed in period costume, representing Joseph Banks and Captain Cook.

The Dominion Museum, renamed the National Museum in 1972, showed a preference for mock period rooms, beginning with a recreation of a pioneer's cottage for the Centennial Exhibition in 1940. Mock period rooms continued to be the main method of representing New Zealand's colonial history until 1992. Period rooms appeared to develop out of the nineteenth-century fairground exhibit (Kaufman in Carbonell 2004, 282) and were first utilised by George Francis Dow in Salem in 1907 (Kaufman in Carbonell 2004, 279). Dow's rooms constructed 'in the typical exposition manner out of a mix of original elements, reproductions, and approximations' were to influence the reconstruction of Colonial Williamsburg, Virginia in the 1920s (Kaufman in Carbonell 2004, 279), and New Zealand museums followed suit. At the Colonial Museum the Elgar collection, a bequest to the museum in 1945, was placed in the context of an appropriate room and was the highlight of the Colonial History Gallery. Mrs Ella Elgar's collection of furniture, outstanding examples of English furniture from the late seventeenth century to the 1820s, was purchased in England to furnish her family's New Zealand mansion, 'Fernside' (Dell 1965, 224). The house, built in the Wairarapa in 1925, was the product of the farming family's success selling wool during World War I (Dell 1965, 224). The Dominion Museum and later Te Papa's interpretation and display of Ella Elgar's furniture show the museum's changing attitudes towards the colonial history collection and its role in the construction of national identity.

In 1982 a colonial cottage was recreated, and Nancy Adams compiled a catalogue titled An Early Wellington House explaining the history of items included in the display. Adams states 'this representation of a simple weatherboard dwelling with a shingled roof shows the kind of house that an early settler might have built in 1842' (Adams 1982). Adams included Maori in her discussion of the early settlement of Wellington, stating how 'the first shelter available was often a small whare built by Maoris of native materials' (Adams 1982). With their extensive use of mock period rooms as a means of displaying objects from New Zealand's colonial history, the National Museum sealed off colonial history. Although the displays were object rich, they lacked narrative, limiting 
the portrayal of colonial history to scenes frozen in time. The museum's commemoration of objects and daily routines, which some New Zealanders could still remember first hand, had been superceded by electrification, piped gas and other new innovations. The display of a colonial solid metal iron, which required pre-heating, perhaps best exemplifies how the period room functioned in the national museum. The representation of colonial daily life and travails was a priority, but broader and more challenging historical processes did not feature. By 1992 the Colonial History Gallery included mock period rooms of a colonial cottage, a bedroom and workshop as well as the grander Elgar rooms.

In 1982 the Colonial History Gallery underwent a major redevelopment. Photos of the Colonial History Gallery, taken in 1980 before the reconstruction, show cabinets full of authentic relics of the past: nineteenth-century objects, including everyday parts of horse drawn carriages, clocks, and horse shoes as well as more noteworthy items such as de Surville's anchor. Before the major redevelopment of the gallery in 1982, the colonial history followed no particular chronological order, but by 1982 the redeveloped space represented a general history of colonisation in New Zealand. By 1982 the term 'colonial history' had become so unpopular the gallery was renamed the History Gallery, attempting to not solely focus on Pākehā history. The redeveloped gallery began with Abel Tasman and Captain Cook's explorations. Cook's cabin, which had been constructed to coincide with the Bicentenary celebrations of 1969, was kept, along with cannon from the Endeavour, and a model of the ship. The redeveloped space now included Maori taonga collected by Cook on his voyages. The space also included a section on early European settlements of whalers and sealers followed by a display of William Wakefield and the New Zealand Company's organised settlement of New Zealand. Large text panels and blown up images were used to explain a general history of whalers and sealers, along with a collection of model whales. All this was displayed around an original blubber pot from the collection. This new approach to display was informative but generalised, resembling blown up pages of textbooks. 
By 1988 elements from New Zealand's social history were included in the History Gallery, as photographs from the period confirm the use of a showcase used to display the history of the Guard family and their objects, bequeathed to the museum in 1984. Photos of the History Gallery in 1990 show a display including a mid-nineteenth century printing press, a two-seater, open carriage, Peugeot Type 54 'Bebe' from 1903, a penny farthing and extensive display of firearms. The display of firearms included a case with weapons used by people of note, including weapons belonging to Governor Grey. The New Zealand Wars were briefly mentioned, as guns associated with conflict were displayed, although the conflicts were not explicitly discussed. The former National Museum avoided addressing nineteenth-century conflicts between Māori and Pākehā. This changed with the opening of Voices He Putahitanga in 1992. Voices was an attempt at a more democratic exhibition. However, like many museums in other places, it ended up by highlighting problems encountered in attempting to 'reimagine national museums in a postcolonial context' (Mason 2007, 98). In Voices, the history of Māori and Pākehā relations were represented through what some argued was an exercise in settler guilt. Te Māori, Taonga Mãori, Treasures and Voices were examples of the transformations taking place in country which officially recognized, to some degree, the wrongs committed against their respective 'first'/indigenous people and adopted policies of cultural diversity to a greater or lesser degree.

\section{The Museum of New Zealand Te Papa Tongarewa Act 1992 and the New Museology} Major developments at the former National Museum 'began in the aftermath of Te Māori in the late 1980s and were contemporaneous with the appearance of the "new museology" , (McCarthy 2007, 169). The 1980s were years of 'great social and cultural change...the decade began as the previous one had ended, with vigorous protest during the Springboks 1981 rugby tour' (McCarthy 2007, 136). There were annual protests at Waitangi, as the Treaty became a focus for Māori grievances and government attempts to settle them, and in 1985 the government gave the Waitangi Tribunal the power to examine claims dating back to the colonial period. Māori made 'considerable political advances in this period and sparked yet another cultural revival through strategic collaboration with Pakehadom' (McCarthy 2007, 137). 
In May 1985 the Labour government put forward plans for a new Pacific Culture Centre (Archibald 2007, 34) and a Project Development Team (PDT) formed to assess the feasibility of the Centre. The project development team for The National Museum of New Zealand Te Marae Taonga O Aotearoa produced a report in 1985 outlining the significant issues facing the development of a new museum. The December 1985 report Nga Taonga o Te Motu: Treasures of the Nation exemplifies the State's conscious ambition to establishment a new museum to be 'a symbol for the nation' (PDT 1985, 7). The Project Development Team recommended a 'National Museum concept as a unifying structure bringing all the cultures of New Zealand closer' (PDT 1985, 7). In their report The PDT recommended quashing plans for a Pacific Culture Centre in of favour of 'a unified institution that better suited the name The National Museum of New Zealand/Te Marae Taonga o Aoteaora (PDT 1985, 2; Archibald 2007, 35).

During the 1980s traditionally held views of New Zealand history were scrutinised and reassessed as Nga Taonga o Te Motu: Treasures of the Nation highlighted a growing desire to rectify the wrong doings of the 'colonial oppressor' (PDT 1985, 7). Indeed, one powerful definition of colonial oppression is that of a people 'whose culture has been smothered by that of a colonising nation and closed to the future' (PDT 1985, 7). In the post-colonial climate of the 1980s, Māori regained control over the management and interpretation of their taonga in the groundbreaking exhibition Te Māori. New Zealand's national identity was challenged as Māori wished to reassert their significance in a politically charged post-colonial climate of the 1980s, and Te Māori 'demonstrated the effectiveness of taonga in helping to convey Māori culture' (Archibald 2007, 36). Indeed, Te Mãori showed how a 'nation's culture and its capital property are not some peripheral part of a nation's life, but lie at its very heart' (PDT 1985, 7). In the new museum Māori art and history would 'evoke awe, admiration and pride in Māori achievement, and inspire the creativity of the Māori people' (PDT 1985, 7). Nga Taonga o Te Motu: Treasures of the Nation defended the proposed separation of Māori and Pākehā culture in the new museum, 'The Team rejects the idea that its recommendations might seek to promote any sense of separation between cultures' (PDT 1985, 7). Instead it believed the 
concept would allow New Zealand's different cultural traditions their own 'special mana and recognition', while allowing 'each to contribute with equal importance to shaping the nation's identity' (PDT 1985, 7).

The Museum of New Zealand Te Papa Tongarewa Act 1992 established the Museum of New Zealand Te Papa Tongarewa. The Act dissolved the Board of Trustees established by the National Art Gallery, Museum and War Memorial Act 1972 and incorporated its institutions, assets and liabilities into the new museum (Department of Justice [DJ] 1992, 2). The Purpose of The Museum of New Zealand Te Papa Tongarewa Act 1992 states outlines Te Papa social responsibilities to:

provide a forum in which the nation may present, explore, and preserve both the heritage of its cultures and knowledge of the natural environment in order better-

(a) To understand and treasure the past; and

(b) To enrich the present; and

(c) To meet the challenges of the future (DJ 1992, 3)

Te Papa's development was grounded in 'New Zealand's particular history and social contexts' (Archibald 2007, 28), echoed throughout the Conceptual Development Plan that formed the basis of the museum's development. The formation of Te Papa with new guiding principals was contemporaneous with new notions of national identity. Te Papa was a 'new class' (MacDonald 2001, 111) of museum, and its development included reinterpreting the place of New Zealand's colonial history and notions of national identity, while at the same time adopting 'new roles, priorities and social responsibilities' (Archibald 2007, 2).

By the late 1980s with the new museology taking full effect, and Te Mãori having revolutionized the interpretation and display of taonga, when Māori 'artefacts' 'were displayed as "Art", on par with fine art' (McCarthy 2007, 135), the National Museum began planning a new New Zealand history exhibition called Voices He Putahitanga. This proposed exhibition attempted to represent a more challenging historical narrative, while bridging the gap between the old style of display and Te Papa's 'post-modern/colonial' (McCarthy 2007) approach under the new bicultural policies of the late 1980s 
and early 1990s. Dominant national socio-political factors, including social responsibility, the renewed interest in New Zealand identity, the development of official bicultural policies and the growing political power of Maori, impacted on the development of Voices. James Belich states, 'Māori history converged with mainstream New Zealand history, and resurgent Māori and their issues moved in from the wings to centre stage' (Belich 2001). This timely and constructive renaissance of Māori and Māori issues within the national historiography and cultural sector also raised issues about how 'Pākehā history' would be represented and commemorated. It was hoped Voices would provide an illustrative test of how the policy of biculturalism, working in tandem with the new museology, could re-interpret colonial history and its place in the formation of national identity. Voices also aimed to address some of the damaging practices and negative interpretations of indigenous cultures in previous museum exhibitions and displays.

When the Dominion Museum opened in 1936, the Māori Ethnology Gallery displayed taonga-like 'artefacts, devoid of their contextual history' (McCarthy 2007, 78). While some argued that national museums were used by dominant parties, including governments, to deny the culture, history and identity of specific groups, Māori culture was 'inseparable from the story of early New Zealand' and 'woven into the very fabric of the colony's pioneer communities' (Dom, 1 August 1936). Slowly Maori material culture was 'taken out of the nature story and inserted into the national story, acting as a prehistoric foil to European history in New Zealand' (McCarthy 2007, 81). Colonial history was regarded as Pākehā history, a celebration of early settler history and the noble pioneer. However, this would all change as Māori started being represented in the History Gallery, which traditionally dealt almost exclusively with Pākehā history. By the late 1980s the National Museum began planning a new kind of history exhibition, one that would incorporate the new bicultural policies. The exhibition, initially titled Journeys and renamed Voices, more actively engaged with 'the new museology' in its attempt to present a more balanced national history. 


\section{Voices}

Voices depicted the history of a pre-contact land of moas, Māori hunter-gatherers, the colonisation of New Zealand and the interaction between Māori and Pākehā. The exhibition was an experiment for future exhibitions at the redeveloped museum's new waterfront site. The significance of Voices lies in its representation of interaction between Māori and Pākehā during the nineteenth century. Voices is symbolic of New Zealand's struggle with national identity during the late 1980s and early 1990s.

Voices was an outcome of the museum's commitment to biculturalism in every aspect of its operation. However, 'becoming bicultural was no easy matter, since nobody was really sure what it was to be bicultural' (Whyte 1993, 12), how its achievement could be measured, or even if it was actually achievable beyond a level of pragmatic responsiveness to Māori concerns and aspirations. There was, however, general agreement that biculturalism required commitment to creating a society in which Māori and non-Māori had equal standing, and where the rationale for change is based on the principles of the Treaty of Waitangi (Graham 1993, 13). The eight-member curatorial team of Voices - four men, four women; four Māori, four Pākehā - took this ideal on board (Whyte 1993, 12). They sought to establish equality of Māori and Pākehā values, perspectives, authority and responsibility in selection and display of objects. In the light of postmodernist critiques, Voices endeavoured to construct a new mode and politics of bicultural and gender-inclusive display, 'aiming to solicit the active engagement of visitors and create an alternative New Zealand history' (Whyte 1993, 12).

An early plan for Voices proposed separate galleries or 'courts,' each addressing a given theme. Court Five of Voices was titled 'Dealings', Court Six titled 'A Treaty - Clash and Accommodation' Court Seven titled 'Poneke - Europeans, for better or worse, try to make the land their own' (Exhibition Concept Development [ECD], 1991). In these early plans the language used by museum staff to represent colonisation has decidedly negative connotations. Court Five of Voices was titled 'Dealings' and focused on how 'Māori and European met and bartered and dealt and traded and exploited' (ECD, 1991). This section hoped to address 'what happened when the two cultures met?' The museum labelled this 
a 'tumultuous time of trade exploitation and warfare' (ECD, 1991). Mention was made of the new-found value of European products amongst Maori, including rifles, iron and crops, while Europeans 'found value in whales, seals and timber' (ECD, 1991). Pākehā settlers were depicted as 'slashers and burners' who 'exploited the resources they found and began to look towards ownership of land' (ECD, 1991). The museum presented colonisation as a difficult moment in New Zealand's history. According to McCarthy, museums in the nineteenth century 'reflected the colonial conflict between settler and native' while at the end of the twentieth century 'they were the scene of attempts to reconcile different forms of decolonization - Pākehā cultural democracy and Māori culture sovereignty' (McCarthy 2007). Although Voices was an attempt to show the museum on the way to 'promoting the idea of two people living in one country' (McCarthy 2007, 169) that would be seen later in Te Papa, Voices focussed on reflecting the conflict of colonisation.

Project director Graeme Tetley hoped the exhibition would 'enable visitors to experience history in an emotional as well as an intellectual way' (Tetley 1992). Tetley stated: 'It's not about walking up to a glass box with a label; there are voices in our history and some of them haven't been heard at all' (Tetley 1992). Voices aimed to present a collision of voices, perspectives and values, instead of a more traditional seamless, authoritative narrative. Through Voices the museum wished to 'redress the imbalance of history and challenge the "master narrative" that has provided our historical perspective up to the present' (Graham 1993, 13). Through Voices the museum attempted a greater level of inclusion, giving equal space to Māori in Pākehā, and in the process the heroic pioneer of earlier exhibitions was placed under the spotlight, resulting in a more critical analysis of colonisation.

The completed exhibition included three spaces or 'courts' that addressed the nineteenth century interactions between Māori and Pākehā. These included 'Meetings, Dealings, Cultural Luggage', 'The Treaty, Barrett's Hotel, Questions of Ownership' and 'New Agriculture and the Māori Response'. The interpretive material which accompanied each display was indicative rather than explanatory, directing attention to contradictory details 
which made apparent the contingent, relational nature of previous historical explanations. Māori were shown to have introduced kumara, but the Pākehā contribution was represented by rabbit pelts. The intention was to engage the visitor in conscious construction of a personal meaning from the array of objects and images presented. However, making sense of what was presented demanded conscious attention, particularly since the recorded material often ironically commented on, or undermined, conventional interpretations for the themes of each display. At the same time, the curators provided details within each court that enabled webs of reference to be drawn across the exhibition as a whole. One such web of connection established a meta-narrative of settlement in which pre-colonial Māori and colonial Pākehā were equally implicated, as two peoples, each with their own discreet histories, but with parallel patterns of settlement dependent on the dispossession of existing inhabitants. However, a selfconscious attempt at a balanced history resulted in Māori and Pākehā spaces that appeared in competition with one another. The Review Team's Executive Summary identified problems when comparing Māori and Pākehā spaces: 'the cultural 'luggage' of the Māori is restricted to a model canoe, some calico sails and a few small artefacts. By contrast we have a ship-sized construction for the Europeans with massive anchor, numerous figures, flags etc.' (Executive Summary 1993). The new bicultural policies reinforced the notion of two cultures in competition with one another.

The interaction between Māori and Pākehā was represented in a section about musket trading: 'Iwi with whom the Europeans had contact started to use weapons to exert themselves over others. Intermarriage began, but the relationships were restricted Pākehā men and Māori women' (Voices Exhibition Text). Court Six attempted to address Māori alarm at the encroachment on their culture and their resources. 'Increasingly they wanted rights recognized by British law. Pākehā 'wished to legalise their settlement' (Voices Exhibition Text). Brett Graham highlighted how from the 'Treaty Court' until the end of the exhibition, we witness a rapid decline. 'As if to compensate for the overcrowding of images in the Maori historical courts, beyond the curtain representing deforestation there is barrenness' (Brett Graham 1992). This accentuated the idea of Māori identities as doomed, not just because of European racist evolutionism, but also 
because of their perceived failures to assimilate. The generalising of tribal identities into a Māori nation went together with what Ian Wedde called a 'generalising of "Māori" failure' (Wedde 1993). Māori economic failure and the European construction of a generalised Māori identity, 'delivered a modern profile which modern communications constantly endorse: of a hegemonic or generalised culture surviving against the odds of economic disadvantage' (Wedde 1993).

The exhibition team were not content with 'the notion that there is one culture of Aotearoa New Zealand, either achieved, or about to materialise' (Tetley 1992). Although each space included Māori and Pākehā voices, negotiating the new bicultural policies was a challenge and the exhibition was heavily criticised. An independent review of Voices said 'the content and concept was flawed, the exhibition was cluttered and curating and research was poor' (Catherall 1993). In the end the loudest voices were those of indignation and outrage as visitors struggled with the subjective interpretation of Māori and Pākehā history.

The museum's seemingly rational and impartial narratives, models and taxonomies, conceal their participation in the promotion of dominant values and power relations. In providing a more polyvocal, non-coherent experience of our past, Voices sought to redeem both institutions. Although the daring and highly experimental exhibition, referred to at the time as a 'work in progress', is not fondly remembered, it succeeded in highlighting the difficulties New Zealand faced in constructing a sense of national identity under the new bicultural framework of the early 1990s. Ian Wedde's critical summary best highlights the failures of Voices, and the complexities of biculturalism. For Wedde, trying to make biculturalism behave like a solution was a 'useless labour' (Wedde 1993, 14), biculturalism 'cannot be a solution or closure' $(1993,14)$, but rather it 'could access a world of high definition, conflict and dispersal' (1993, 14). Wedde went on to state that 'in this utopia, we would visit Voices with incredulity and relief, view it as an anachronism, a relic, a reminder of how bad things had got' (Wedde 1993, 14). The challenges of the new bicultural policies and more specifically the constructing of a bicultural national identity was reflected in Voices, which symbolised New Zealand's 
own struggle for identity in the early 1990s. The significance of Voices lies in the impact of the exhibition on the development of the Day 1 history exhibitions, which more overtly embraced a mandate promoting a New Zealand national identity within bicultural parameters.

\section{Getting to Our Place}

During the 1980s there was a struggle to form new identities as 'decolonization accelerated both the cultural nationalism which sought a new identity for Pākehā and a Māori nationalism which sought greater political autonomy' (McCarthy 2007, 116). Jock Phillips recalled the 'difficulties with the politics of the situation' (Phillips 2001, 146), as Te Papa's redevelopment coincided with a period in which the country struggled to form a new national identity. The annual reports from this period remained optimistic, while Gaylene Preston's documentary Getting to Our Place showed the realties and difficulties of developing the museum's central and arguably most important exhibition, Signs of a Nation.

By 1993-1994, Te Papa's five Guiding Bicultural Principles 'provided the basis for a credible and effective bicultural institution' according to Cheryll Sotheran (Annual Report 1993-94, 3). As a bicultural museum, Te Papa Tongarewa was '....a place where the two sides of New Zealand's mainstream cultures can be seen to encounter each other, to speak with all their voices and to be heard' (Day 1 Exhibition Conceptual Plan [ECP], 1994, 4). New relationships with ngā iwi Māori developed as the Māori advisory network made significant contributions to exhibition development and museum policy (Sotheran 1993-94). Indeed, a strong Māori presence in senior management had a 'transformative impact on Museum operations at staff level' (Sotheran 1993-94). As Te Papa 'became a testament to the growing influence of Māori culture on the formation of New Zealand's national identity' (Archibald 2007, 40), there was growing suspicion that Māori exhibitions would been given more space than their due; and that the Māori exhibits would be celebratory and affirmative, while the non-Māori exhibits would be cynical and questioning (Phillips 2008). The idea that the Museum was 'politically correct' and 
overly sympathetic to Māori resulted in cries for walls of white pioneering heroes, and exhibitions highlighting Pākehā achievement (Phillips 2008).

During this period New Zealand sought to redefine who they were, and while 'politicians and people looked to the museum to provide them with simple and accessible truths' (Philips 2008), Phillips was suspicious of 'simple slogans and unquestioned certainties ...all my instincts told me of the value which came from debate, complexity and contradiction' (Philips 2008). Phillips identified how the revival of Māori culture and identity (Philips 2008), and the creation of a Waitangi Tribunal to explore Māori grievances under the Waitangi Treaty had produced an unstable combination of guilt, defensiveness and anger among many Pākehā (Philips 2008). According to Phillips, Pākehā 'did not want to be reminded of their culture's misdeeds' (Philips 2008). Realising a new series of history exhibitions on the new Cable Street site would therefore prove contentious and challenging. In the exhibition Voices, curators had an excellent example of how the exhibition of colonial history in New Zealand could cut to the heart of questions of identity and cherished national myths. Following Voices, Te Papa's Project Development Team sought to provide varied notions of identity and reveal how identity is 'formed, contested and celebrated'(ECP 1994, 10).

Te Papa's 1994 Day 1 Exhibition Conceptual Plan proposed the division of Māori and Pākehā exhibition spaces, placing each culture into the areas of Tangata Whenua (the people of the land, the Māori) and of Tangata Tiriti (the people who were in New Zealand by virtue of the Treaty of Waitangi). Under biculturalism, Te Papa afforded Māori culture equal status, and visitors would see relationships between Māori and Pākehā 'at work with equal focus in a wide variety of exhibitions where the voices and perspectives of Māori and Pākehā have equal force' (ECP 1994). Pākehā history would be represented on the Tangata Tiriti side of level four, along with other ethnicities who were 'in New Zealand by virtue of the Treaty of Waitangi'. Though questions of what constituted Pākehā history was becoming a major conceptual issue, at an operational level 'the matter was quickly solved' (Phillips 2008). Phillips argued, perhaps questionably, that there was no Pākehā identity as such, instead, Pākehā had co-opted an identity as New Zealanders 
and their definitions, as Phillips quickly discovered, included Māori. So the history exhibitions addressed New Zealand identity from a Pākehā perspective.

Both New Zealand and Singapore grappled with the challenge of forging national identities from profoundly multi-ethnic constituencies. Both societies also carried the burden of a legacy of inter-racial violence and colonial exploitation, but the challenges in the two societies were also quite different. Singaporean leaders obsessed over the avoidance of inter-ethnic conflict, using 'Singaporean-ness' as a new identity that could displace ethnic tension, giving all ethnicities a stake in the Chinese-dominated island state. In New Zealand, state institutions propounded biculturalism as a means to accommodate resurgent Māori identity and political clout. Nonetheless, the use of history is both countries' museums have been deeply political as both national museums pursued the overt objective of fostering and influencing national identities. The new museology furnished both institutions with a potent tool with which to undertake this task. Given the importance of the colonial period as a foundational moment for both Singapore and New Zealand, the NMS and Te Papa needed to grapple with colonialism. How these museums exhibited colonisation has profound implications for how they also construct and interpret national identity.

The next chapter explores the development of the Day 1 history exhibitions. By analysing the representation of colonial history in Te Papa's Day 1 exhibitions, chapter three explores how New Zealand's national identity was re-imagined in the 1990s. Te Papa hoped to address the cultural traditions of both Treaty partners, not only expressed as 'distinct entities, but brought together within the Museum to complement and challenge each other in their similarities and differences' (ECP 1994). As Te Papa successfully represented an inclusive bicultural nation through exhibitions such as Signs of a Nation, it fell short of confronting the colonial period and history of interaction between Māori and Pākehā, with the exclusion of the exhibition space aptly named Encounters. 


\section{Chapter 3. Re-imagining the nation in a postcolonial context: History exhibitions at Te Papa $1998-2009$}

This chapter explores the relationship between the representation of history in Te Papa's Day 1 exhibitions and the construction of New Zealand national identity in the late 1990s. By examining Te Papa's redevelopment projects and analysing the completed Day 1 exhibitions, this chapter shows how Te Papa pursued policies with the objective of promoting a vibrant and inclusive national identity, based on the premise of biculturalism. By comparing Te Papa's history exhibition with the National Museum of Singapore's History Gallery this chapter shows how the social and historical contexts of each nation shaped distinct visions of national identity. Rhiannon Mason argues that depictions of nations in national museums inevitably involve revision, readjustment and re-presentation in response to national contexts (Mason 2007). Indeed, Te Papa's redevelopment was influenced by changing politics, social issues and curatorial trends, which included the new political ideals of biculturalism.

As seen in chapter two, Te Papa also began realizing aspects of the new museology in the 1980s, evident in approaches taken to the history exhibition Voices. I have described how this prototype exhibition was a forerunner to the Day 1 history exhibitions that envisaged Te Papa as a forum and 'fulcrum for the nation' (Archibald 2007, 57). In Te Papa's 1993/94 Annual Report, Chairperson Sir Wallace Rowling declared 'that the Museum will be an outstanding symbol of New Zealand's nationhood: an embodiment of our national identity' (Annual Report 1993/94). Te Papa was thus redeveloped in accordance with new ideals and priorities, including the challenge of being sensitive to and inclusive of an increasingly multicultural society. These new approaches are evident in Te Papa's Day 1 Conceptual Plan, completed in March 1994, which outlined the importance of 'customer focus, biculturalism and commercial positivity,' within the broader themes of ‘journey, place and identity’ (ECP 1994, 5). The Conceptual Plan shows how Te Papa attempted to combine recognition of diversity with a continuing commitment to a national culture. 
The Conceptual Plan outlined Te Papa's framework in which a range of exhibitions would 'meld Aotearoa New Zealand's diversity into a coherent and powerful group of exhibitions' (ECP 1994, 5). Jock Phillips, whose essays shed light on the construction of national identity within the practicalities of exhibition development, recalled how he thad to do something about national identity...' (Phillips 2008). Historian Bronwyn Labrum, a concept developer and curator who worked on Passports, On the Sheep's Back and Signs of a Nation, also recalled how 'the museum was all about national identity' (Labrum 2008). These three exhibitions formed the backbone of Te Papa's attempt to tackle the vexing challenge of promoting and interpreting national identity. Much like Voices, a close examination of the development and final form of Passports, On the Sheep's Back, Exhibiting Ourselves and Signs of a Nation shows how the notion of national identity shapes and is shaped by history exhibitions.

\section{The Thematic Approach}

The Day 1 Exhibition Conceptual Plan from 1994 proposed a thematic approach to the history exhibitions rather than a traditional chronological grand narrative. As Jock Phillips recalled, 'I decided a chronological walk through would be boring' (Phillips 2008). Curators used a thematic approach to history, and proposed three different explanations for New Zealand's national identity. The Exhibition Conceptual Plan from March 1994 outlines the conceptual framework: 'The History exhibitions are linked by two main themes - migration and identity' which pose the question - 'Who are New Zealanders?' (ECP 1994, 41). Phillips conceived of three explanations for New Zealand's identity which would be addressed in the history space on the Tangata Tiriti side of level four. The first exhibition proposed that New Zealand's identity was determined by those who settled here. Phillips stated: 'one explanation is that it comes from the old world....we are the product of the people who settled in New Zealand' (Phillips 2008). The next exhibition offered the notion that New Zealand's identity was determined by unique social experience in New Zealand. In response to this idea Phillips explained: 'I wanted an exhibition that was about the kind of distinctive social experience that emerged here, confronting a new world' (Phillips 2008). This space was to comprise of a series of short-term exhibitions dealing with aspects of New Zealand's social history, including 
Love in New Zealand, an exhibition on gambling and On the Sheep's Back: a loving look at wool. The final space suggests New Zealand's national identity is simply a construct. This idea was highlighted in an exhibition that explored the different ways national identity had been represented in international exhibitions. Phillips stated 'the other way of looking at Pākehā identity is that it's actually a bit of a fiction, a creation of the mind' (Phillips 2008).

The three history exhibitions - Passports, On the Sheep's Back, and Exhibiting Ourselves - provided different way of approaching the question of New Zealand identity. One answer was that New Zealand identity, and more specifically non-Māori identity, was a product of the people who settled New Zealand. The second exhibition took the opposite hypothesis. It concentrated upon interaction with the New Zealand environment. It proposed that distinctive patterns of life emerged after people arrived in New Zealand. The development of a distinctive way of life is also explored:

the growing consciousness of a New Zealand identity, highlighted in moments of achievement or conflict and read in the conscious symbols or displays that are sent back out to a wider world. We are the people and cultures that came here. Are we also what we think we are? (ECP 1994).

The thematic representation of New Zealand's history at Te Papa markedly contrasts with the History Gallery at the National Museum of Singapore. At Te Papa a thematic approach to the re-telling of history creates a diffuse and complex illustration of New Zealand's history. In contrast, the National Museum of Singapore contains tightly constructed chronologically arranged exhibits of a didactic character.

Te Papa's separation of cultures affected the representation of New Zealand's history. On Te Papa's level four, history was separated, as 'decolonization and biculturalism were inscribed into the architecture' (McCarthy 2007, 170). At the centre of level four stood the Treaty exhibition Signs of a Nation, which 'operated conceptually and architecturally as the hinge of the nation' (McCarthy 2007, 170) [fig 13]. The Exhibition Conceptual Plan from 1994 proposes a Māori section for the new museum, incorporating Māori art and history. The Exhibition Conceptual Plan proposes another section called 'History'. 
This section suggests exhibitions linked by two main themes - migration and identity. Interestingly, these early history exhibition concepts include Māori stories in the 'Tangata Tiriti' side of level four: 'There could be an exhibition here on migrations out of New Zealand or within New Zealand (e.g. Māori migration to the city)' (ECP 1994, 42).

The Exhibition Conceptual Plan thus envisaged a complex and sensitive exploration of identity. Unsurprisingly, these early plans provoked discussion and some criticism, including a conservative backlash. During the early 1990s, as Te Papa redeveloped, 'there was a clamour for simple nationalist affirmations from the Pākehā community' (Phillips 2008). Phillips and Te Papa were not prepared to provide a gallery of 'heroes, a hall of fame from Sportsmen and VC winners', nor was Te Papa happy to 'reinforce images of noble pioneers and archetypal figures in black singlets' (Phillips 2001, 148). Although Phillips recognised the legitimacy of searching for national identity, he was 'determined not to give simple answers' (Phillips 2008). The aim was to lay out the material so people could see this question of identity as open to a number of answers and provide the visitor with 'the means to come up with their own formulation' (Phillips 2008). This democratising approach to the representation of history was part of a strategy to make Te Papa a forum for the nation, honouring aspects of the new museology.

Te Papa's adoption of aspects of the new museology, including greater social inclusion, accessibility and inclusion of biculturalism, affected the approach taken to the reinterpretation of history. Te Papa's corporate goals of the 1990s reflected New Zealand as a more inclusive society in which race and gender were recognised. Te Papa was conscious of 'Gender Issues' (ECP 1994, 7) and endeavoured to 'tell all our stories', 'adopt a lateral and inclusive approach to storytelling', and place 'all New Zealanders in touch with their heritage in stimulating and exciting ways' (ECP 1994, 7). Phillips rejected the grand 'master narrative' approach in favour of more accessible and inclusive history exhibitions. In contrast, the National Museum of Singapore provides the visitor with less autonomy, as The History Gallery presents a chronological and progressive history of Singapore in the "tradition of "seamless, authoritative "master narrative", (McCormack and Leonard 1993, 12). 


\section{Biculturalism: Māori and Pākehā history}

Te Papa's development did not occur in isolation from contemporary politics and social issues, but instead 'influenced and was influenced by them' (Archibald 2007, 59). In turn, constructions of national identity at Te Papa influence and were influenced by the Day 1 history exhibitions.

This is what is meant when museum redevelopment project are described as being both products and processes; while they result from specific historic circumstances, they also contribute to ongoing social and political developments through their roles as cultural communicators and facilitators (Archibald 2007, 59).

A significant political and social issue impacting on the redevelopment of Te Papa was the notion of biculturalism. As stated in the Exhibitions Conceptual Plan, 'the Museum of New Zealand Te Papa Tongarewa is a bicultural museum' (ECP 1994, 6). Te Papa hoped to develop an exhibition framework which 'allows the expression of Māori and Pākehā perspectives, and invigorates the discussion between the Treaty partners' (ECP 1994, 6). The cultural traditions of both Treaty partners were not only expressed as distinct entities, but were 'brought together within the Museum to complement and challenge each other in their similarities and differences' (ECP 1994, 6).

The conceptual structure of Te Papa informed the physical layout of exhibition spaces. The ground floor of the museum would address Papatuanuku, 'the land on which we stood' (Phillips 2001, 147); and the floor above, examining culture, would be divided into the area of 'Tangata whenua (the people of the land, the Māori) and Tangata tiriti (the people who were in New Zealand by virtue of the Treaty of Waitangi)' $(2001,147)$.

Jock Phillips reflected on the complexities of developing the 'non-Māori' exhibitions stating, 'Pākehā, let alone all non-Māori, do not think of themselves as having a separate identity...they think in terms of New Zealand identity' (Phillips, 148). Phillips accepted this point and pitched the exhibitions around the question of 'New Zealand identity, not Pākehā identity' (Phillips 2008), understanding Pākehā recognition of New Zealand identity as a Pākehā concept: 'this was not a racist way of expanding a Pākehā definition into a nationalist whole' (Phillips 2008). As many Pākehā included Māori culture within 
their definitions and symbols of New Zealand identity, many Māori in turn participated within a broad New Zealand identity. Phillips judiciously decided Māori people and Māori elements should be included within these exhibitions where appropriate. Although Phillips hoped for a seemingly integrated history of New Zealand, the final history exhibitions were decidedly polarised. There were plans for an exhibition that would have linked the two sides of level four, but unfortunately this never eventuated and the nineteenth century colonial history of interaction between Māori and Pākehā was largely absent.

The Exhibition Conceptual Plan proposed an exhibition space called Encounters, which would occupy the area directly opposite the Treaty exhibition Signs of a Nation. Encounters [fig 14] would address 'the rich history of the encounters between Tangata Whenua and Tangata Tiriti' (ECP 1994, 64). This exhibition would sit between the Māori exhibitions and the Pākehā exhibitions, representing the history of interaction of Māori and Pākehā. It would 'select a number of themes or subjects which illustrate this history and develops a series of exhibitions around them' (ECP 1994, 64). These exhibitions were not 'sequentially linked to each other but stand alone, the linkage being that they all describe encounters'(ECP 1994, 64). There were a large number of possible subjects including:

The New Zealand Wars, Religion, Tourism, Music and Looking at Each Other, (This latter component would explore the different ways in which Māori and Pākehā have represented and still represent each other in art, cartoon, song, writing, theatre and cinema) (ECP 1994, 64).

The Aims of the Encounters space included an 'exploration of different facets of the Treaty relationship' (ECP 1994, 64). It was not an explicit account of the history of the Treaty since 1840, but 'it serves that broad purpose by exploring themes and subject related to encounters' (ECP 1994, 64). This approach was deliberately selected to avoid presenting a 'large, didactic exhibition of the Treaty, which may alienate the audience' (ECP 1994, 65). The Treaty of Waitangi exhibition was meant to be a 'small and simple statement of the content and substance of the Treaty itself' (50\% Concept Design). It was hoped Encounters would complement the Treaty exhibition by developing and exploring the Treaty relationships. Yet Encounters never eventuated; instead a café was built in the 
space and an exhibition addressing historic interactions between Māori and Pākehā was excluded from Te Papa.

\section{Signs of a Nation}

Te Papa hoped to use the Treaty of Waitangi, one of the most significant moments in New Zealand's colonial history, to construct a sense of national identity. Yet the museum struggled to implement the Treaty-themed Signs of a Nation [fig 15], an exhibition that presented but also glorified the bicultural ideology on which New Zealand's identity was based in the 1980s and 1990s. Signs of a Nation was the most politically contentious exhibition at Te Papa and arguably the most significant. It was an exhibition about the Treaty of Waitangi, the central document of the modern history of New Zealand, the basis on which the bicultural society is established (ECP 1994, 61). It has a central place conceptually in the museum, as it is central to all the stories and exhibitions which relate to New Zealand society since 1800 and 'especially the interactions between Tangata Whenua and Tangata Tiriti' (ECP 1994, 61). The aims of the exhibition as stated in The Day 1 Exhibitions Conceptual Plan from March 1994 were to:

convey the fundamental place of the Treaty as New Zealand's founding document and its continuing importance in New Zealand society today, as well as an understanding of the Treaty's three articles, especially as they relate to contemporary New Zealand (ECP 1994, 60).

Signs of a Nation stands in an imposing wedge-shaped space, underneath a high cathedral-like ceiling, with its 'comfortable seating and calm ambience, the setting offers a place for quiet contemplation' (Te Papa). The Treaty document itself, both as a giant replica and with the words of its two versions hung on opposite walls, is the focus of the exhibition. While Te Papa uses religious imagery to describe Signs of Nation as a quiet place of reflection, there is a more vigorous undercurrent in this exhibition. At its heart Signs of a Nation is about national identity in the 1990s. The exhibition goals stated that 'visitors will recognise that the Treaty of Waitangi is the basis of the bicultural partnership of Tangata Whenua and Tangata Tiriti and that this partnership is the basis for a culturally diverse New Zealand society' (ECP 1994, 60). 
Through Signs of a Nation the Treaty became a symbol for New Zealand's national identity, or more specifically the country's bicultural identity. Visitors were invited to engage with an aspect of New Zealand's history, as Te Papa attempted to present the Treaty as a current document with contemporary significance rather than an historical artefact from the nineteenth century. The history of the Treaty was minimized as Te Papa emphasized the overwhelming significance of the document today. Unlike the Treaty House at Waitangi, where the history of the Treaty is retold in text book detail, Te Papa's approach due to its contrasting ambitions was markedly different. The historical context in which the Treaty was signed on 6 February 1840 was not emphasized - this would only highlight the historic features. Instead, visitors were encouraged to understand the Treaty 'as relevant to all New Zealanders regardless of culture and origin at a national level' (50\% Conceptual Design). Signs of a Nation hoped to educate the public on current treaty issues as "visitors will be equipped with the basic knowledge to understand the background behind current Treaty issues' (50\% Conceptual Design). It was hoped that Signs of a Nation would clarify the content of the Treaty and assist visitors to 'address misunderstandings or anxieties they may have about the Treaty (issues like claims over private land, for example)' (ECP 1994, 61).

An early conceptual design of Signs of a Nation stated that visitors arriving at level four from the lifts or the stairs will be greeted by the giant words of the Treaty which 'will draw them closer and signal that here is the heart of the museum' (50\% Developed Design). Signs of a Nation was highly experiential and never aimed to present a traditional history exhibition. Historical context, in the form of large information panels, was relegated to an out of-the-way nook. The exhibition's 50\% Developed Design stated how Signs of a Nation would be:

a sacred place, a powerful place, a dignified place where all New Zealanders will respond to the clarity and simplicity of the actual words that expressed a vision of two people seeking to co-exist peacefully in one country (50\% Developed Design, 2) 
The Treaty exhibition concepts presented in the 50\% Developed Design suggest a powerful exhibition more akin to a religious experience than history exhibition. Relying on simplicity, and by using light as a living medium, it was hoped the words of the Treaty would 'form a metaphorical roof of a house under which all are welcome' (ECP 1994, 61). By using modern technology combined with the words of the 1840 document, the Treaty team hoped to demonstrate that the Treaty was a living document. It was hoped this approach to display would 'encompass the spirit of peace that the Treaty was entered into, the abrogation of it over most of its history and the more recent moves towards reconciliation and honoring its principals' (ECP 1994, 61). Te Papa emphasized the notion of the Treaty of Waitangi as 'a living social document, debated, overlooked, celebrated' (Te Papa). .

As the visitor walked into the exhibition, they were encouraged to engage with the large versions of the Treaty's three articles in English and in Māori, and the great glass facsimile of the 1840 document. To add life and to personalise these words, the reflections and personal stories of those whose lives have been affected by the Treaty were added using audio soundtrack. Moving into Signs of a Nation, the visitor passed through a thicket of pole clusters. Here many voices can be heard, presenting the different views of New Zealanders on the Treaty, with quotes from the time of signing through to current opinions. Signs of a Nation reflects a democratic approach in its representation of the 'founding document', in which a multitude of voices was heard. To emphasise its living and experiential qualities, Signs of a Nation did not rely on text panels to lead the visitor through the history of the Treaty of Waitangi, although informative swivelling panels were displayed on the mezzanine floor behind the glass Treaty. The large information panels reflected the democratic approach to display, as Māori history featured on one side and Pākehā history on the other.

Signs of a Nation was a product of the 'new museology', rather than presenting one authoritative voice, a multitude of opinions were played on an audio soundtrack through the large pou (or talking poles). It was Cliff Whiting's hope that Signs of a Nation would 'engage and make information accessible ...giving the opportunity to measure the 
progress as a country addressing race relations practices' (Whiting 1996). The voices coming from the pou 'could not be more different in their views on the Treaty' as they represented 'the thoughts of ordinary New Zealanders' (Te Papa wall text). There was certainly no strong authoritative master narrative; instead there was emphasis on inclusion of Māori and Pākehā impressions and interpretations of the Treaty. This was extended in Pepper's Ghost, a film of actors performing the roles of different New Zealander's throughout history and their opinions of the Treaty. Few objects were included in the exhibition. A surveyor's chain from about 1900, made from steel and brass, has been displayed in Signs of Nation. The surveyor's chain is viewed as a symbol 'of the British colonial approach to dividing up the land and owning it' (Te Papa wall text).

Te Papa uses Signs of a Nation to question whether the Treaty of Waitangi is 'an irrelevancy or the platform on which all New Zealanders can build a future?' (Te Papa wall text). The significance of Signs of a Nation lies in the way it uses the history of this document to construct a sense of our nation as bicultural. Signs of a Nation is a contemporary commentary on the Treaty of Waitangi and its centrality to the wider New Zealand community.

\section{Passports}

Te Papa's history exhibition Passports [fig 16] proposes that New Zealand's identity, and more especially non-Māori identity, is a product of the people who settled New Zealand. The exhibition dealt with the immigrant experience from the early nineteenth century, the period of British mass-migration after 1840, and more recent waves of migration from Europe, Asia and the Pacific. The primary hypothesis of the exhibition, originally known as The Peopling of New Zealand, was 'New Zealand - nation of immigrants' (Phillips 2001, 148). Passports was divided into three sections, life back in the mother country (Leaving the Homeland), the journey to New Zealand (Crossings) and the arrival in a new land (A New Country). The first space of the exhibition includes videos and maps detailing the lives of a selection of regional British and Irish migrants. This section 
includes blown-up quotes on the walls, revealing the migrant's reasons for leaving their homeland, and personal keepsakes review-able in a series of drawers. The drawers incorporated the stories of early nineteenth century settlers, including Biddy of the Buller, who arrived in Nelson in the 1860s in search of gold. Biddy Goodwin associated objects included a clay pipe, a piece of river gold and a green gin bottle, along with an original image. The second section representing the journey to New Zealand is a dark and cramped space, reflecting the steerage quarters of a nineteenth century immigrant ship. Front-end evaluations were carried out in an attempt to better understand New Zealander's perception of their history and identity and to reconcile popular 'misconceptions regarding New Zealand history' (FEER 1995, 59). The summary of the Front-End Evaluation Report (FEER) highlighted key issues the History Team needed to address during the early stages of Passports concept development. The front end evaluation revealed key misconceptions about New Zealand's colonial history including: 'there were few women in New Zealand in the nineteenth century', 'Few people emigrate to New Zealand on a permanent basis' and 'the majority of migrants travelled directly to New Zealand' (FEER 1995, 59).

The Front-End Evaluation Report, a document which addressed visitor needs, also highlighted how the re-telling of New Zealand's history of settlement had to 'cover a range of ethnicities and cultures' (FEER 1995, 58). Consultation with various communities who were to be included in Passports was an important way of ensuring the presentation of cultures was appropriate (FEER 1995, 58). Dr James Ng, a specialist on Chinese migration to New Zealand, was contacted as part of a growing recognition that the success of the Passports exhibition 'depended on a mutually beneficial and supportive relationship' between the Museum and the community (FEER 1995, 60).

A central interpretive strategy of Passports was to explore and link 'global socioeconomic processes (such as the expansion of industrial capitalism) with everyday life through the use of individual "stories" (CDD date unknown [D/U], 5). Through the use of 'personal testimonies' to provide multiple perspectives of the past, Te Papa hoped to avoid "the temptation to treat excluded groups as "virtuous victims"" (CDD D/U, 5). To 
ensure the exhibition team reflected a diverse range of experiences, criteria were used in the selection of 'stories' including: 'Time of arrival, Gender, Class, Country of Origin, Religion, Age, Motivation' (CDD D/U, 5).

Jock Phillips wanted visitors to identify with the immigrant experience, 'to realise that the traumas of migration are universal and that this is a founding experience for all nonMāori New Zealanders' (Phillips 2001, 150), and visitor empathy with the migrant experience was a vital element in the success of the exhibition. In an attempt to involve the visitor in the immigrant experience, Phillips proposed how: 'At the entrance you are invited to pick up a passport which tells the story of one immigrant, and you can stamp that passport and learn what happened to that individual at each stage of the journey' (Phillips 2001, 150). The visitor was invited to become involved in a large number of personal stories scattered in various places throughout the journey (Phillips 2001, 150). It was intended that such stories would break down cultural stereotypes, and 'reach across barriers to express diversity of reaction to New Zealand' (Phillips 2001, 150).

Respondents in the front-end evaluations were asked to describe identity, with the main emphasis being 'focused on cultural identity, belonging to a particular group and what is our national identity' (CDD D/U ). The Front-End Evaluation Report revealed confusion regarding the terms bicultural and multicultural: '...people expressed concern about the messages the notion of biculturalism sent to New Zealander who were not of Māori or Pākehā descent' (FEER 1995, 56). According to Phillips, political pressures were severe in the development of Passports, as suspicion grew 'that we were going to emphasis the small number of minority immigrant groups - nineteenth-century Germans or twentiethcentury Pacific Islander - to the exclusion of the British majority' (Phillips 2001, 150) who have comprised some 80 per cent of New Zealand's immigrants. The front-end evaluation had revealed that 'respondents thought that the majority of early settlers were male workers, primarily of English descent'. However, a range of other nationalities were also identified in relation to early settlement, including Chinese, Yugoslavian, French and Dutch (FEER 1995, 56). But the museum's board still felt it important to give full representation to the British majority, although there was still a lingering fear surrounding 
the representation of British settlers. The board in particular remained uneasy about the representation of British settlement; fear was largely due to the loving presentation of Māori taonga, which would not be balanced by similar affection for non-Māori culture. Phillips response to these political concerns was to 'confront the visitor with a wall of treasures at the entrance of Passports - a photographic and object-rich display designed to show off some of the contributions which the non-Māori have bought to New Zealand' (Phillips 2001). Phillips desire for an object-rich display was never realised, as the entrance of Passports is relatively sparse.

Arguably the least successful of the three sections of Passports is the final section, A New Country, which addressed the immigrant's reaction to their new home. Phillips stated that the final section would address how settlers learnt to adjust to the new country (Phillips $2001,150)$. However, in the completed exhibition it is as if European settlers arrived to an uninhabited land. A New Country incorporates the stories of early settler families, including the Guard family, who represent the early whaling communities, the Saxton family, who represent the Nelson experience, the Vlaars, who represent the Dutch community and the Dalmatian community, who represent gum digging (CDD D/U, 15). The primary cognitive objectives and outcomes included,

that many different groups of people have made their home in New Zealand and that migrants have brought a diverse and rich range of traditions, beliefs and ideas to New Zealand and continue to do so (CDD D/U, 15).

The story of the Guard family was retold with the help of original Guard family possessions and a painting titled The Rescue of John Guard, 1884 [fig 17], which depicts Māori and Pākehā interaction. The history of display techniques and museum interpretation of both the Guard Family collection and the Elgar collection exemplifies the museum's shifting attitudes towards the display of Pākehā culture and colonial history. The Rescue of John Guard is a small water colour representing an event that occurred in 1834 in Ngati Ruanui tribal territory in Taranaki. Although the event has a factual basis, the representation is purely imaginary. The work depicts a Māori warrior attempting to flee with a Pākehā baby while two British seamen struggle to rescue the baby. In the 
background a small army of Māori approach with weapons, while above them a group of redcoats fire rifles down at the group below.

When Te Papa opened in 1998 the trilogy of exhibitions Passports, On the Sheep's Back and Exhibiting Ourselves represented New Zealand's history of colonisation without the colonised. Māori history was represented in Mana Whenua, as the bicultural framework of level four excluded any significant representation of Māori and settler interactions. Stories of settler arrivals were included in Passports, but the seminal moment of New Zealand's history, the meeting of Māori and Pākehā, was given minimal attention as Encounters, the exhibition that proposed to address interactions between the two cultures, was abandoned.

\section{Exhibiting Ourselves}

Exhibiting Ourselves [fig 18] presented the idea that identity is a projection which is captured by certain groups at certain time for particular ends. It included recreated filmset-like spaces of the great Exhibition of 1851, the 1906 Exhibition in Christchurch, the 1940 Exhibition in Wellington, and Seville Expo '92. Phillips hoped that by looking at the recreations of early exhibitions, 'visitors would make the leap in a post-modern kind of way and begin to ask how far Te Papa's displays too were time-bound constructs' (Phillips 1997, 149).

The idea to develop an exhibition about exhibitions was driven by the fact that when Phillips looked at Te Papa's collections it was 'strong in terms of what had been used at international exhibitions' (Phillips 2008). Certain strengths in Te Papa's collection also led Phillips to take a thematic approach to New Zealand's history: 'when I looked at the collection, I realised it was pretty poor in lots of ways' (Phillips 2008). Phillips decided thematic exhibitions would 'provide the best use of the collection and also provide a kind of variety of tones' (Phillips 2008). By replicating a series of international exhibitions to create the idea that 'identity is an artificial construct, it's a deliberate construct that changes over time, and it's a reflection in a sense of the need of people at different points in time, it's always changing' (Phillips 2008). 
The 1851 section aimed to 'strongly evoke the beauty and technological sophistication of the Crystal Palace through the use of glass and steel' (90\% Developed Design).The section also aimed to show how New Zealand's colonial status influenced its presentation at the Great Exhibition. According to the exhibition's 90\% Developed Design, the primary cognitive objective of this section was to show how 'New Zealand presented itself as a land of abundant natural resources' (90\% Developed Design). This section also aimed to show how 'New Zealand's colonial status influenced its presentation at the Great Exhibition' (90\% Developed Design). By including The Gilfillan lithograph of Putiki Pa, a model Pa and Māori Taonga of the type that were displayed at 1851, it would 'demonstrate the role of Māori in national identity in 1851'(90\% Developed Design). The section on the 1906 Exhibition in Christchurch aimed to show how the Exhibition reflected New Zealand's growing 'confidence and optimism', while portraying itself as a “"natural wonderland” for tourists' (90\% Developed Design, 11). This section also aimed to reflect how the 1906 Exhibition 'was characterised by feelings of confidence and optimism about New Zealand's future' ((90\% Developed Design)). Te Papa showed how Māori presented elements of their own culture at the 1906 Exhibition. This section included Ruato tomb carvings, a photo-mural of carvers, and Peter Buck and Maggie Papakura's stories. This section highlight how 'New Zealand presented itself as a progressive society, based on the idea of the 'social laboratory' (90\% Developed Design).

Exhibiting Ourselves was a nostalgic trip through the history of New Zealand's participation in exhibitions. The constructed-ness of exhibitions and expo's was recreated at Te Papa, resulting in a self-conscious look back at our short history of national identity construction. Te Papa's 1995/96 Annual Report states that New Zealand 'forged an identity through four international exhibitions, beginning with the great Crystal Palace exhibition of 1851, and culminating in Seville's Expo '92' (Annual Report 1995/96, 9). But Exhibiting Ourselves was actually a comment on constructed-ness of national identity. It hoped to leave the visitor pondering the notion of their own identity, and the role the state and exhibitions play in the formation of identity; 'if we are not a land of wine, cheese and yachting rather than rugby, racing and beer' (Annual Report 1995/96, 9). 


\section{On the Sheep's Back}

On the Sheep's Back [fig 19] was an exhibition proposing the notion that our identity comes from the distinct social experiences of life in New Zealand. Displays of white settler history had long been a part of New Zealand museums. Before the Second World War, New Zealand museums, along with those in other former British settler colonies, were devoted to natural history, ethnography or art, rather than 'history' per se (Labrum 2009, 11). The 1940 Centennial Exhibition and the anniversaries of the previous decade stimulated a growing interest by Pākehā in their history and heritage. The interest in preserving and promoting Pākehā history during this time was reflected in the Dominion Museum. According to Amiria Henare, historical collections and displays have functioned as memory places for Pākehā and formed a whiggish, largely triumphalist and laudatory accounts of settler pioneers who broke in the land and built up the country in to what it had become today (Henare 2005). Sociologist Claudia Bell, who visited many New Zealand museums in the first half of the 1990s, saw a Pākehā 'folk-history' in displays that "appear determined to bowdlerise political issues, offering "untainted" myths of colonial life' (Bell 1996, 68-69). Furthermore, 'preference stays with a decorative version of the past, providing a conservative history for undemanding consumers' (Bell 1996, 68-69).

The development team for On the Sheep's Back addressed focus group findings in an attempt to present a more 'intriguing, amusing and informative' (ECP 1994) exhibition about New Zealand life. The focus group findings revealed how 'all groups were interested in the social history of wool' (Focus Group Findings 1993, 16), including the history of sheep, the hardships and struggles involved in farming, manufacturing processes and woollen art and fashion $(1993,16)$. The team incorporated the following findings into the development of On the Sheep's Back, presenting a contemporary social history exhibition markedly contrasting the 'musty, out of date exhibitions at Buckle Street' (Focus Group Findings 1993, 9):

Move beyond "nostalgia ad" to wool as social, economic, cultural force. Things that happen because of wool - how it was grown traded, worked, transported, sewn, knitted. Social conflict and the future of wool (woman aged 45-49). 
On the Sheep's Back was an open plan exhibition divided into three spaces, each space told the diverse histories of those involved in the New Zealand wool industry. The first space, titled Grassy Empires, placed Ella Elgar's antique furniture alongside a shearing shed display that included a large original wool press. The second space, titled Woollen Yarns, like Grassy Empires juxtaposed objects from different cultures. In Woollen Yarns a diverse range of products, including Swanndris, blankets and Mar-Annette Hay's elegant dresses, produced in New Zealand wool factories, were displayed in front of large a black a white photographs of factory interiors. The final space, titled Home is where the Art is, represented how wool became a feature of domestic production and handcraft in New Zealand (CDD 1996, 44). This section predominantly focused on objects produced by women and included tea cosies, knitting objects and jerseys. Each section took a playful approach in representing the diverse uses of wool in the lives of a range of New Zealanders.

For Bronwyn Labrum, a historian and concept developer, On the Sheep's Back 'was a way to talk about something that was important and serious in our history, the contribution of wool and wool growing to the New Zealand economy' (Labrum 2008). It was also broad enough to 'take in knitted textiles, knitted togs, to have designer fashion in it, to have a change in collection of tea cosies' (Labrum 2008). Labrum, like Phillips, remembers the public's apprehension surrounding Te Papa's display of Māori and Pākehā history:

...there was a lot of political concern about Te Papa, what was happening? What kind of museum it was going to be? Was it going to be a Māori museum full of Taonga? Was it therefore downgrading Pākehā culture and Pākehā history? (Labrum 2008).

Bronwyn Labrum also led the development of Love in New Zealand, an exhibition which never eventuated. Love in New Zealand was supposed to take a broad look at love. It was playing to Te Papa's collection strengths 'using collections from wedding dresses to Margaret Sparrow's collection of contraceptives, to wedding cars, to romance and dating' (Labrum 2008). According to Labrum, it was a lighter, quirkier look at identity than Passports or Exhibiting Ourselves (Labrum 2008). Te Papa's Board rejected Love in New Zealand. Some believe this was due to the seemingly controversial display of 
contraceptive devices and the inclusion of same sex romance, deemed too politically provocative.

Gaylene Preston's documentary Getting to Our Place follows the development of Te Papa. One scene of the film shows former chairmen of the board Sir Ron Trotter, a descendent of South Island farmers, talking about sheep farmers and the heritage of breaking in the land. Sir Ron Trotter's experiences contrast with Georgina Te Heu Heu, who talks about her whakapapa. The politics of biculturalism and the polarisation of Māori and Pākehā spaces was something the curators even struggled with. Although though On the Sheep's Back was on the Tangata Tiriti side of level four, which addressed Pākehā history, Labrum did not believe she worked on exhibitions that dealt exclusively with Pākehā history. For Labrum, it was impossible to discuss the wool industry without discussing the contribution of Māori shearers. She recalled how 'at the time there was all this angst about the place and the value of Pākehā culture, history and identity, so we had very strong messages that we were to stick with Pākehā history and the exhibition team railed against that' (Labrum 2008). In the end, On the Sheep's Back succeeded through its inclusive approach to Māori and Pākehā history, as the final section of the exhibition entitled Home is where the Art is displayed Māori cloaks and other traditional Māori crafts, including korowai, alongside wool handcraft produced by Pākehā.

The overall cognitive objectives of On the Sheep's Back included an understanding 'that race, gender and class issues have affected the processes of wool production and use' (ECP 1996). It was hoped that a large black and white photograph of a Māori shearing gang, displayed opposite the finery of Ella Elgar's Fernside display, would represent the Māori contribution to farming in New Zealand. Ella Elgar's grandfather, Charles Pharazyn, had brought sheep into the Wairarapa as early as 1845 . Her collection of furniture had long been displayed in the Colonial History Gallery at the National Museum. Te Papa decided to incorporate Ella Elgar's story with that of the early wool barons who acquired their wealth 'on the sheep's back'. The Elgar collection became 'a symbol for the way the European heritage was being short-changed in the museum' (Phillips 2001, 154). The Pharazyn family were used as an example of an early successful pioneer family 
and their story was included in the Grassy Empires section. Their story is one of hard work and prosperity, as the exhibition imbued the Elgar Collection with a sense of pride in the early settler's achievement. Opposite Grassy Empires was a section entitled Shear hard work, which focused on the harsh masculine environment of the woolshed. Both Grassy Empires and Shear hard work glorified the farming communities' strong work ethic and farming successes, at the same time as echoing On the Sheep's Back humorous and light-hearted approach to social history display.

Kirstie Ross, currently a history curator at Te Papa, reflected on her time working on the new twentieth century history exhibition which is due to open at Te Papa in 2010. Ross also discussed Blood, Earth, Fire, an exhibition she assisted in developing. Blood, Earth, Fire opened in 2006. Going beyond On the Sheep's Back, Blood, Earth, Fire exemplifies Te Papa's changing approach to the representation of national identity. In Blood, Earth, Fire Māori and Pākehā stories sit alongside each other, as a struggle for equal space and representation is no longer the main objective. Blood, Earth, Fire looks at the economic and environmental implications of two groups of settlers in New Zealand, Maori and Pakeha. It explores how the two groups transformed the environment according to time and culture and how that affected their economic activities, the extent of their environmental impact and how they tried to resolve the subsequent impacts on the environment. Māori and Pākehā are depicted coming into contact over the issue of land. Te Papa explores how a colonial economy based on agriculture meant that a Māori conception of land and occupation and economic use had to be shifted to European notions of ownership. Scholars call it a tenurial revolution, from communal title to individual title. The transfer of Māori land is depicted through the use of maps (Ross 2008). The exhibition also briefly discusses the New Zealand wars and the role they had in expediting the transfer of land, therefore depicting the reality of a colonised country in which two cultures interact.

As shown in this analysis of the history exhibitions, Te Papa's approach to national identity has changed since the 1990s. According to Ross, from the perspective of 2008 the Day 1 history team 'reduced all history to the history of national identity' (Ross 2008). 
Ross felt that earlier New Zealand historians 'rationalised history to sceptics by saying we need history because it will tell us who we are as a nation... I don't feel I need to rationalise history' (Ross 2008). For Ross the very notion of national identity is part of a colonising discourse, and she prefers to use the term 'New Zealand-ness' rather than national identity. Ross believes that 'New Zealand-ness is just one of the outcomes of history and there are other identities that arise simultaneously, including a sense of being Māori, , a sense of being Pākehā, a sense of being a woman ...' (Ross 2008). Today's visitors at Te Papa expecting to see the nation reflected back at them in the form of slogans, experience Blood, Earth, Fire, an exhibition which aims to show how history is more than an aspect or component of national identity. Indeed the drive to construct national identity at Te Papa may have lessened. However, Blood, Earth, Fire is still an exhibition which endeavours to tackle national identity, albeit a more benevolent kind.

The late twentieth-century concept of national identity is no longer visible at Te Papa in 2008, as the original trilogy of Day 1 history exhibitions have been gradually deinstalled and replaced with new exhibitions, including Blood, Earth, Fire. Te Papa's history exhibitions were products of their time, as this study shows. New Zealand's particular socio-historical contexts shaped the construction of national identity, fostering an inclusive bicultural vision of the nation for the 1990s. This chapter demonstrates how Te Papa's history exhibitions were active agents in the re-imagining of national identities, cultures, histories and memories. Te Papa's history exhibitions reflected New Zealand's identity as 'no longer based on an exclusive nationalism, but the fundamental idea of unity through multiplicity' (Beier-de Haan 2006, 189). Te Papa replaced the idea of the nation-state with an emphasis on 'the formation of a national consciousness...nationalism was still given significance as a force of integration and reconciliation' (Beier-de Haan 2006, 189). 


\section{Conclusion}

This dissertation began by posing the question of how the museum display of colonial history constructs national identity. It drew on work by Mason, Davison, Poole, Zuelow and others who have presented post-Anderson views of identity as more than a cultural construct, and responded to the call from Fiona McLean for a more in-depth understanding of how this identity was remade, negotiated, maintained, contested and debated. Clearly, history plays a key role in strengthening a sense of nationhood. This study shows that the museum exhibition of history is inextricably linked to the process of 'national storytelling' in museums (McLean 2007, 329). Using specific historicallygrounded local case studies which provide a glimpse into the internal development of museum exhibitions, the dissertation demonstrates that both the NMS and Te Papa were and are engaged in cultural activities aimed at fostering Singapore and New Zealand national identity respectively, sanctioned by the state, but mediated through their own staff and adapted to particular situations and demands. The redevelopment of the NMS and Te Papa reflected both Singapore and New Zealand's evolving cultural, political and social priorities. The analysis of these colonial history exhibitions demonstrates what the nation 'means' as 'an on-going project, under constant reconstruction' (Hall 1999, 14), as the nation's history is constantly adapted to serve successive generations.

While globalization weakens the connection between national pasts and the future, the NMS and Te Papa updated their history displays in an attempt to 'intensify acceptance of diversity of cultures and identities, while reinforcing weaker identities' (Beier-de Haan, 188). This study suggests that both the NMS and Te Papa used colonial history as a 'foundational moment', central to the construction of new independent national identities for a new postcolonial age. Both institutions reset the past in relation to the present themes of multiculturalism and biculturalism, central themes in their respective history exhibitions. At the NMS the idea of multiculturalism brought the history of Singapore's disparate migrant population together, and promoted the idea of 'unity within diversity' in contrast to ethnic conflict and division. In contrast, the physical implications of bicultural policies on Te Papa's level four meant Māori culture was given equal status, at 
the same time as dividing Māori and Pākehā history into separate idealised sections that belied the reality of entwined contact.

The introduction established the theoretical framework for this study, analysing the relationship between national identity and national museums. In the literature review I drew on new work on this topic to argue that national identity is not just an 'imagined community' but rather a concept undergoing continual re-interpretation. This dissertation therefore avoided any discussion of what might constitute a 'real' nation or national identity, concentrating instead on the formation, articulation and propagation of the concepts themselves. The introduction outlined the range of research methods employed to answer the research question and fill the gap in the literature showing how the representation of colonial history shaped the construction of national identity. Using primary and secondary sources, interviews and other qualitative research methods, the NMS and Te Papa's colonial history exhibitions were contextualised in their own time and place. Each chapter shows how views of the colonial past at the NMS and Te Papa were 'made over' in response to changing governmental policies and historical circumstances. Chapter one demonstrated how the NMS, employing aspects of 'the new museology', as a state organisation supported cultural projects that aim to foster national identity, representing an inclusive vision of the harmonious multicultural state. Chapters two and three showed how Te Papa developed various visions of New Zealand's identity in a trilogy of exhibitions which emphasised equality and inclusiveness. Chapter three also showed how Te Papa adopted elements of 'the new museology' (Vergo 1989) in its subtle and inclusive approach to culture and history.

National museums were traditionally accorded the elevated status of keepers and purveyors of culture, as religious terms such as 'shrine', 'temple', 'spiritual' and 'church' have been associated with them (Bledisloe 1934, 2; Davison 2006, 92-3; Macdonald and Alsford 1989, 3-5, 37; Nicks 1992, 91). In the era of 'the new museology', which encouraged reflexive practices, unqualified acceptances of the 'truth' in museum messages makes practitioners and academics alike extremely uncomfortable. My research shows the different ways in which the NMS and Te Papa engaged with 'the new 
museology', resulting in more open and egalitarian representations of their histories that included multiple viewpoints. With the inclusion of multiple viewpoints, the NMS and Te Papa's history exhibitions reflected a questioning of traditional certainties and master narratives. However, the NMS exhibition was somewhat more conservative and structured in its display techniques, while Te Papa more fully embraced 'the new museology', providing a selection of interactive, thematically-structured exhibitions that encouraged the visitor to form their own answers in relation to the questions posed. This included the very notion of national identity, which was openly debated in Exhibiting Ourselves. In 1998 Te Papa, like other new museums, was 'not so much a place of instruction and dissemination, but a space which facilitated communication, discussion, exchange and interaction' (Karp and Lavine 1991, 32).

The NMS represented a progressive chronological national history contrasting with Te Papa's diffuse, thematic presentation of history. The History Gallery at the NMS contained powerful messages germane to Singapore's nationalistic nation-building projects. The visitor to the NMS was presented with a singular vision of Singapore's past, experienced in the chronological display which narrated the fledgling nation from beginning to end. The NMS's History Gallery, like Singapore, was less concerned with individual freedom; rather it strove to reflect the multiculturalism of Singapore, promoting social and political harmony and collective identity. The NMS's overt Singaporean national identity promotes harmony as a way of diffusing ethnic tension. In the History Gallery all major ethnicities get a stake; freedom to be Indian or Chinese is being Singaporean. Indeed the goal of constructing national identity at the NMS appears a more overt ambition than at Te Papa, which 'did not want to prescribe a standpoint; instead, it aims to bring out the heterogeneity of perspectives; it seeks not to judge or direct, but to identify and allow "bipolarity"' (Gorbey 2001).

Te Papa presented a liberal and critical version of national identity, providing a foil for New Zealanders to explore their diverse and plural past, present and future. It recognised the importance of Māori culture as key to constructing an inclusive and politically harmonious vision of the nation's past for the postcolonial present. The analysis of Te 
Papa's exhibitions Signs of a Nation, Passports, On the Sheep's Back and Exhibiting Ourselves shows how Te Papa promoted a vibrant and inclusive national identity. The museum did not dictate a singular national identity; instead they provided a trilogy of unconventional, diverse history exhibitions exploring a number of themes which proposed several different overlapping national identities. The museum avoided using an authoritative narrative in retelling the story of New Zealand's past, but in including some aspects of that story excluded others such as the history of interaction and conflict between Māori and Pākehā.

This study fills a number of gaps in the literature on this topic, and responds to calls for 'a deeper understanding of the ways in which museums negotiate and construct meanings of national identity' (McLean 2007, 329). It follows up the work of Archibald on Te Papa by providing a historically-contextualised account of contemporary exhibition development; like Mason, Poole et al it treats identity as a mediated process of maintenance as well as a product of external forces and ideologies; and it deals with an Asian national museum together with a post-settler state. It differs from other studies, which traditionally concentrate on external, discursive aspects of new museums by concentrating on the internal processes and behind-the-scenes development of exhibitions. In comparing different approaches to the topic in these two museums, this research demonstrated similarities and differences in museum practices in New Zealand and Singapore. In these ways, and most especially by bringing together interesting new work on museums and identity from a range of disciplines, this study makes a significant contribution to museum studies and most particularly the analysis of Te Papa in New Zealand which has become an orthodoxy .

As Archibald concluded in her study of Te Papa and the Canadian Museum of Civilisation, museum redevelopment projects are frequently described as both products and processes: while they result from specific historic circumstances, they also contribute to ongoing political developments (Archibald 2007). My research has built on this research by showing how the construction of national identity is not independent from socio-historical contexts, and that history exhibitions draw on aspects of the past, 
depending on the particular national requirements. Literature on new museums often focus on current museum trends, suggesting that what is new is in some ways isolated from previous practice. However, museums do not exist in isolation 'from politics and social issues, rather they influence and are influenced by them' (Archibald 2007, 59). This study favours an overall historical progression which shows that the construction of national identity is part of a process and continually under construction.

Both New Zealand and Singapore have faced challenges inherent in reconciling cultural differences, but the formation of such national flagship institutions is seen by some as the start of new relationships and, in the case of Te Papa, recognition of the importance of Māori culture. Since the settlement of Treaty claims over the last two decades, and the subsequent drive to redefine New Zealand as 'bicultural' in the 1980s, there has been widespread debate about a basis from which the country's people, Māori and Pākehā, can create new partnerships and relations.

National museums play a key role in helping citizens to understand and interpret their country's histories by acknowledging past failures and successes and changing their policies to reflect and acknowledge their responsibilities as keepers of collective memories. By incorporating the tenets of 'the new museology' (Vergo 1989), national museums can stay relevant in society by making positive contributions, including fostering a sense of national identity to promote inclusiveness and diversity. This study shows how providing a forum which people can visit in order to encounter both their own and other cultures is important in multicultural countries like Singapore and New Zealand. 


\section{Illustrations}

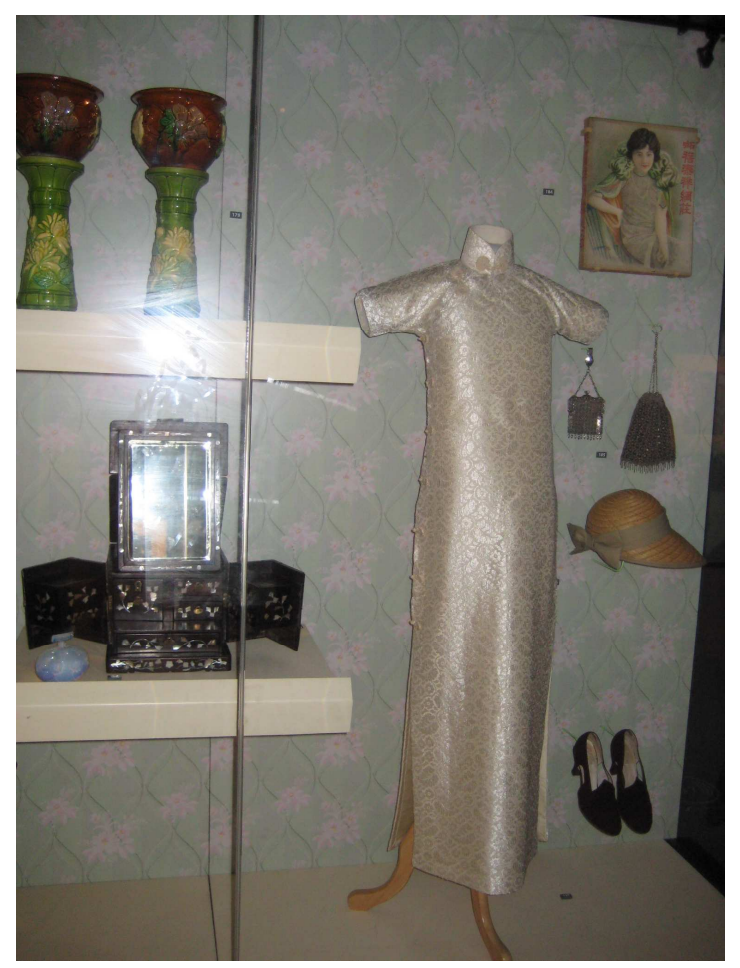

Figure 1: May Wong display, National Museum of Singapore. 2008. Photograph Julia Waite

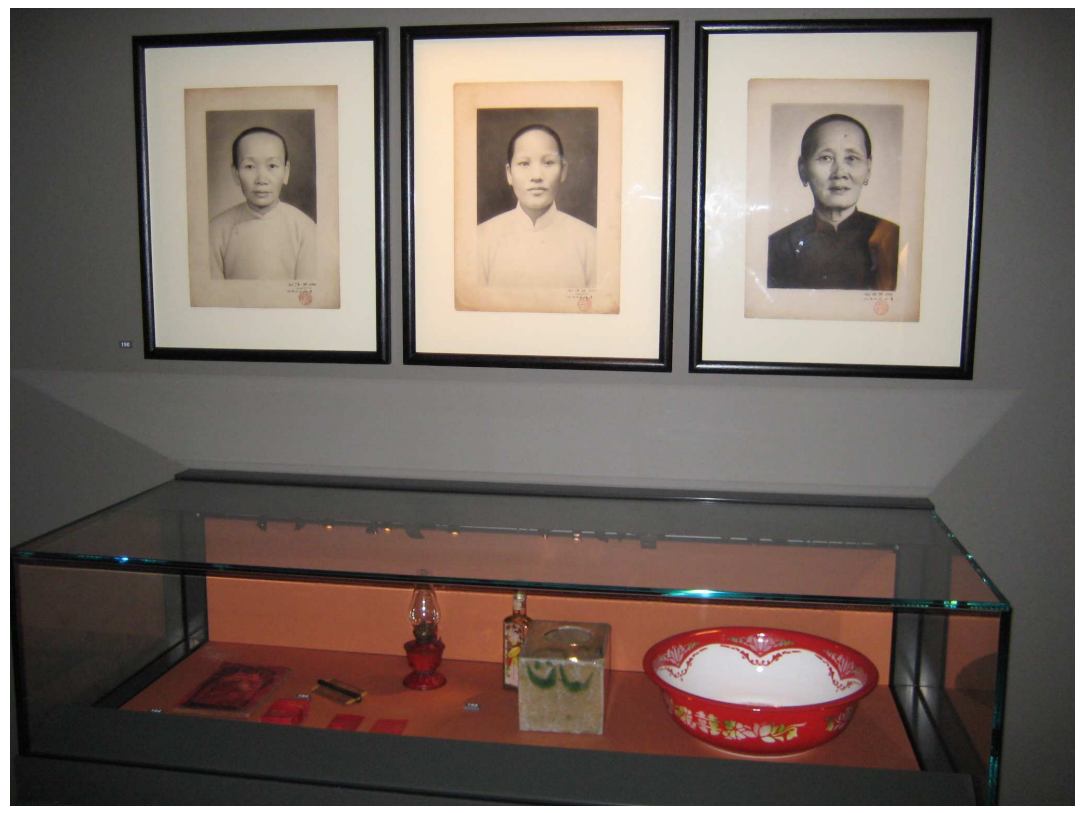

Figure 2: Amahs display, National Museum of Singapore. 2008. Photograph Julia Waite 


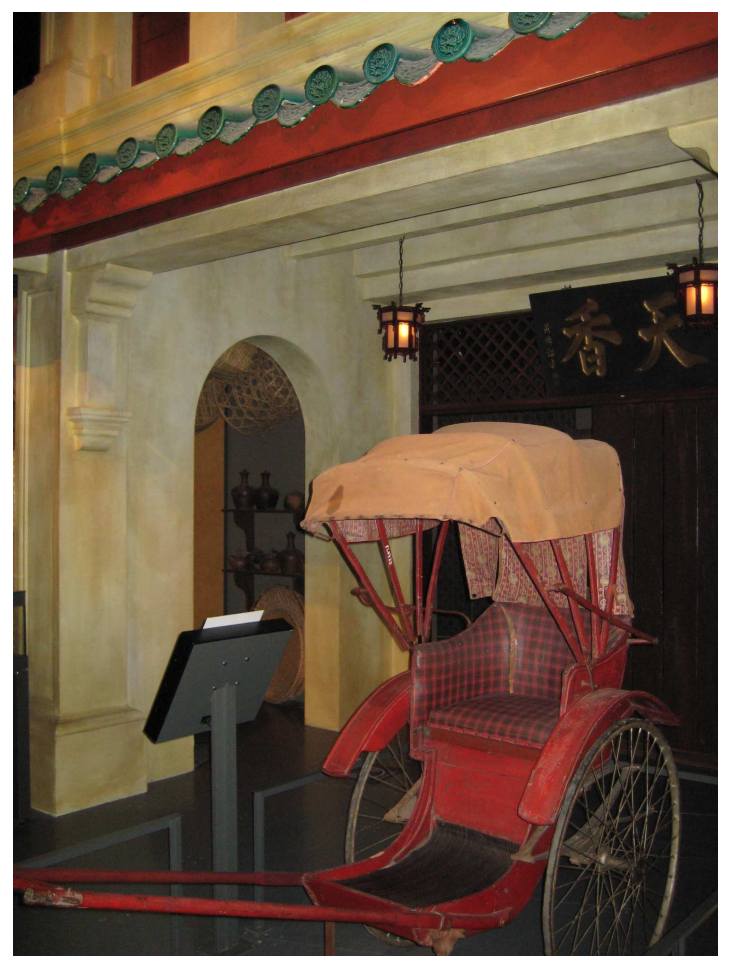

Figure 3: Rickshaw Singapore display, National Museum of Singapore. 2008. Photograph Julia Waite

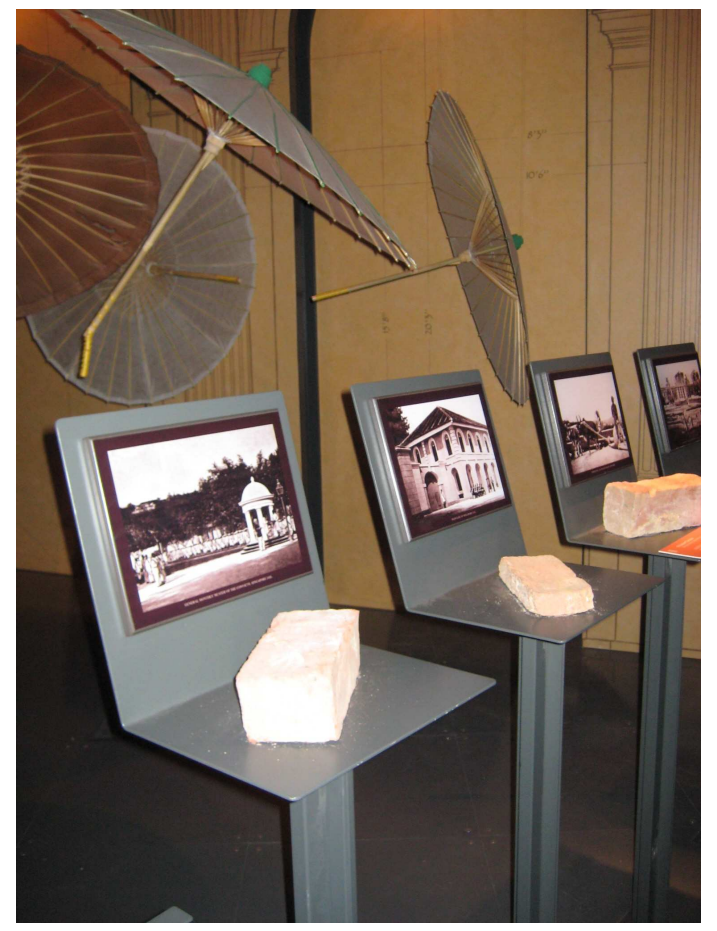

Figure 4: bricks in Richshaw Singapore display, National Museum of Singapore. 2008. Photograph Julia Waite 


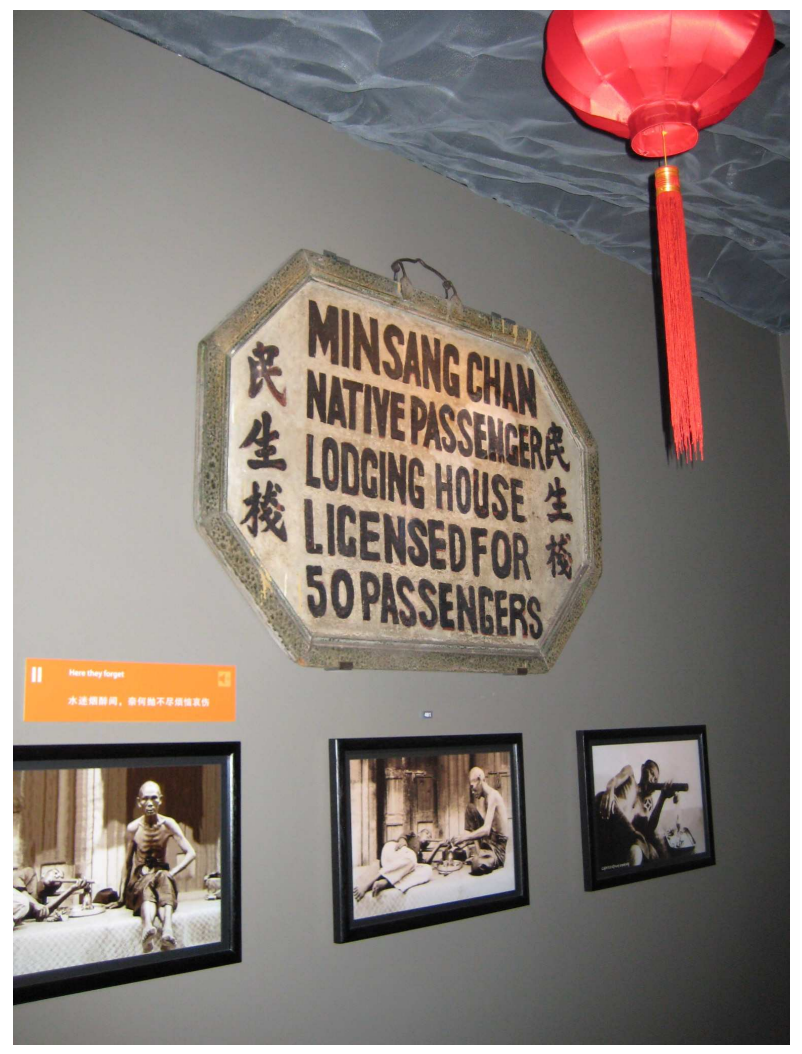

Figure 5: Chasing the Dragon display, National Museum of Singapore. 2008. Photograph Julia Waite

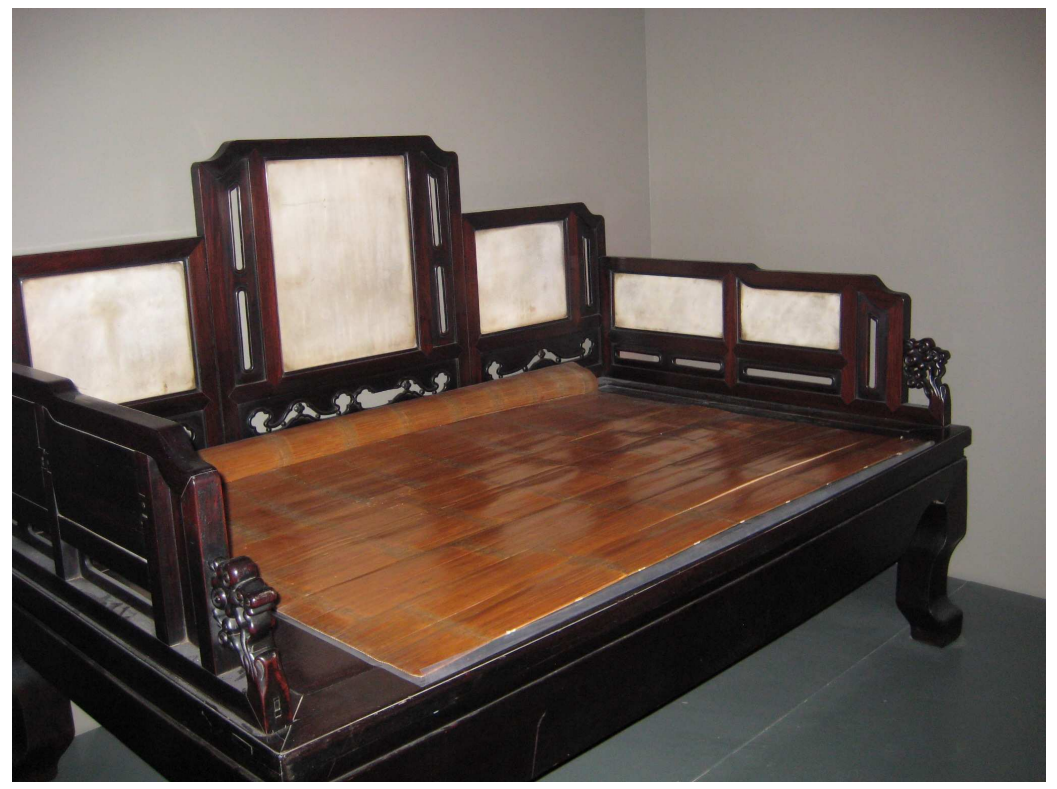

Figure 6: Opium "bed" in Chasing the Dragon display, National Museum of Singapore. 2008. Photograph Julia Waite 


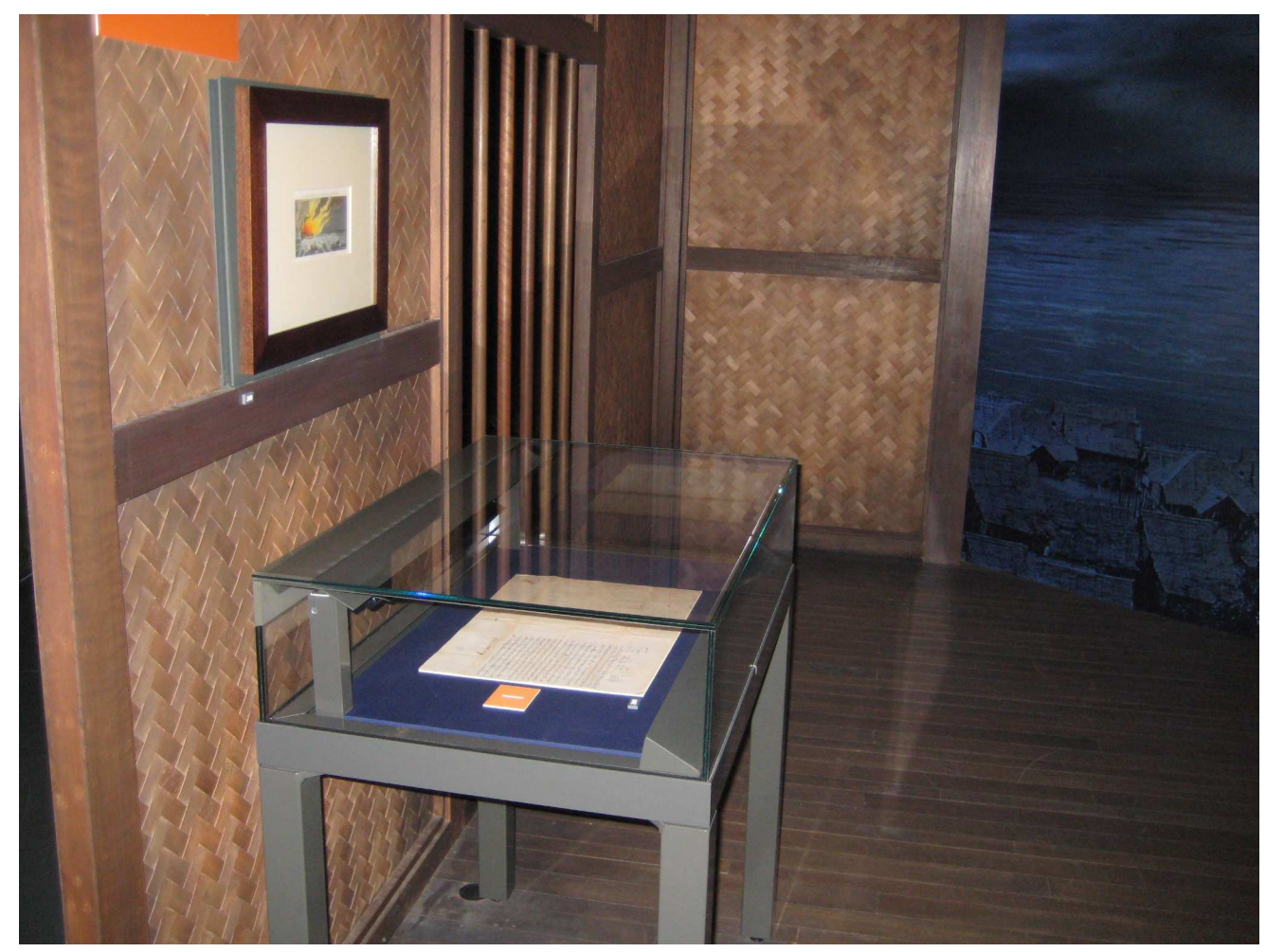

Figure 7: Munshi Abdullah display, National Museum of Singapore. 2008. Photograph Julia Waite 


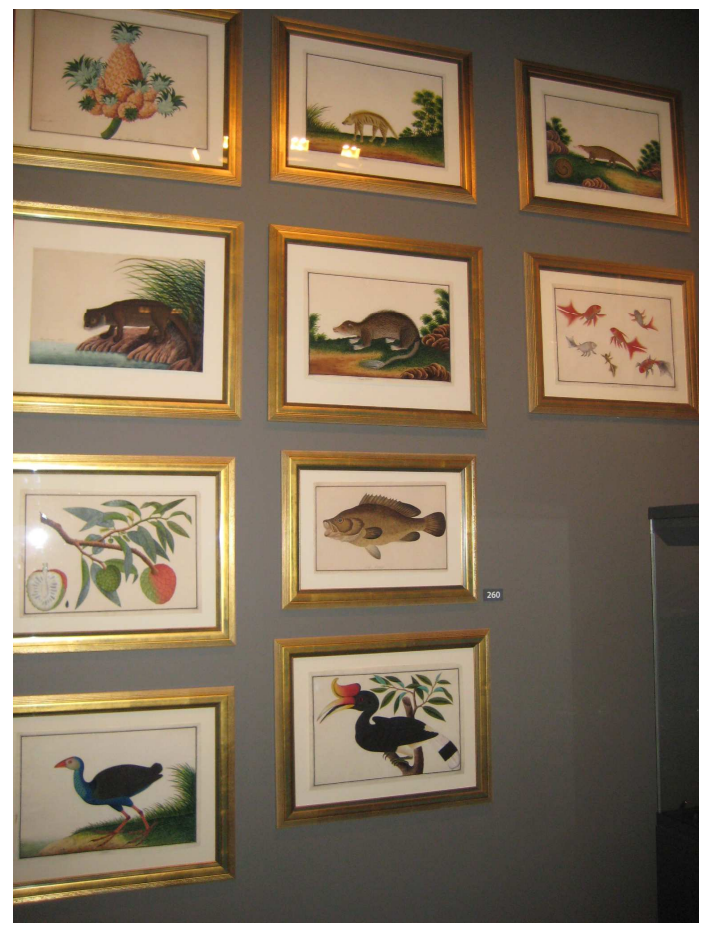

Figure 8: William Farquhar display, National Museum of Singapore. 2008. Photograph Julia Waite

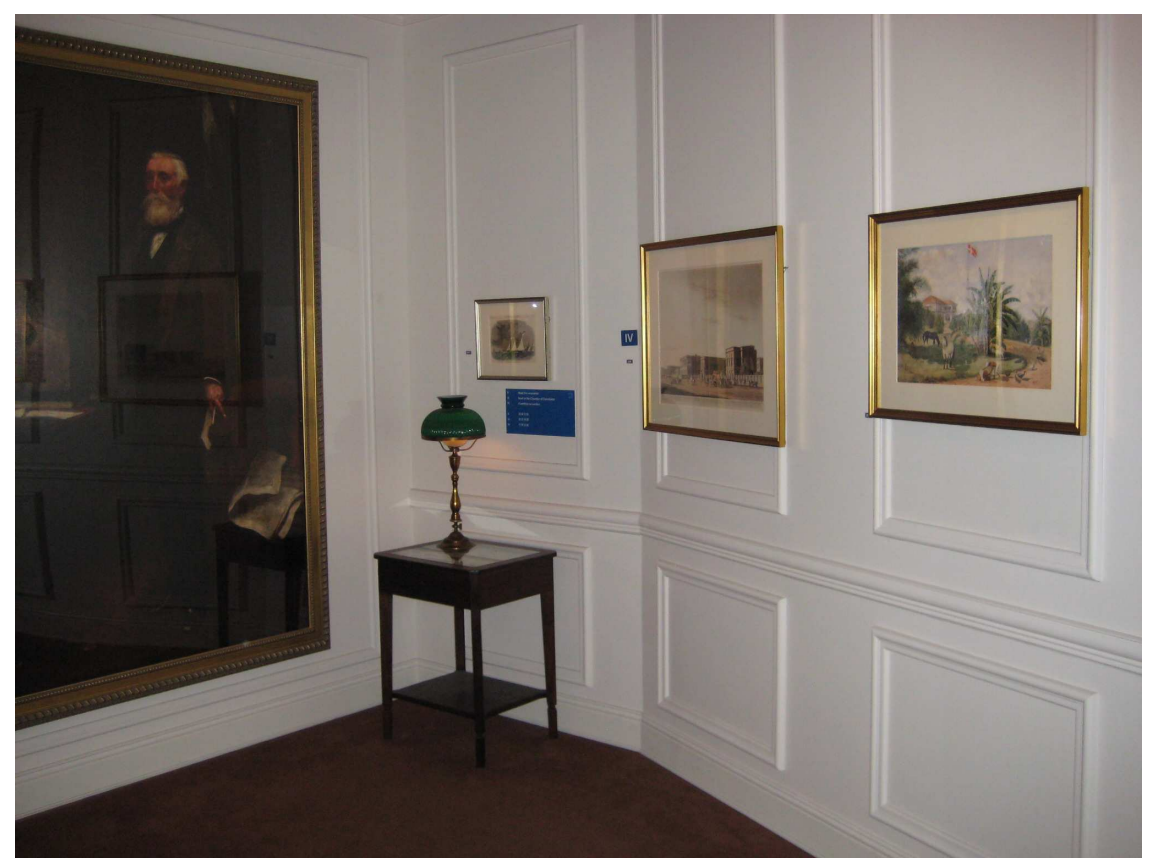

Figure 9: William Read display, National Museum of Singapore. 2008. Photograph Julia Waite 


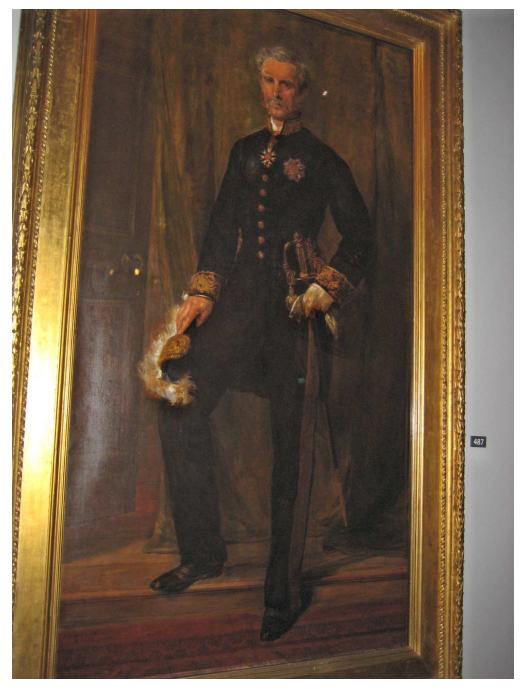

Figure 10: Portrait of Cecil Clementi Smith,

National Museum of Singapore. 2008. Photograph Julia Waite

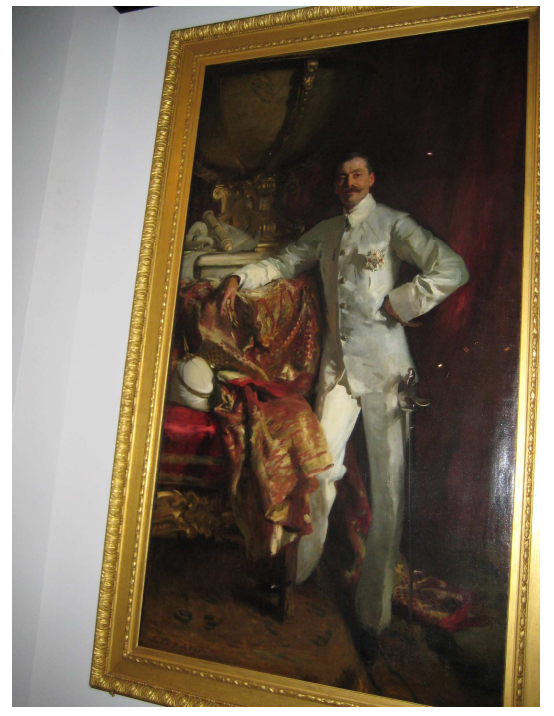

Figure 11: Portrait of Sir Frank Swettenham,

National Museum of Singapore. 2008. Photograph

Julia Waite

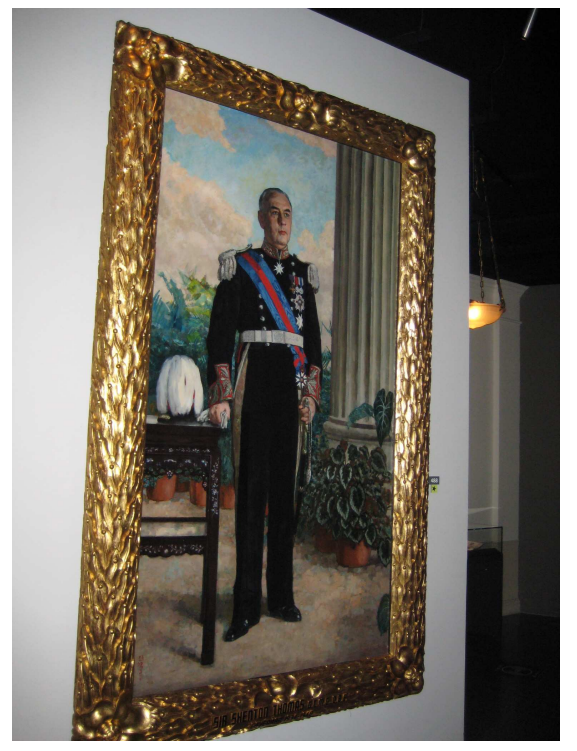

Figure 12: Portrait of Sir Sir Shenton Thomas, National Museum of Singapore. 2008. Photograph Julia Waite 


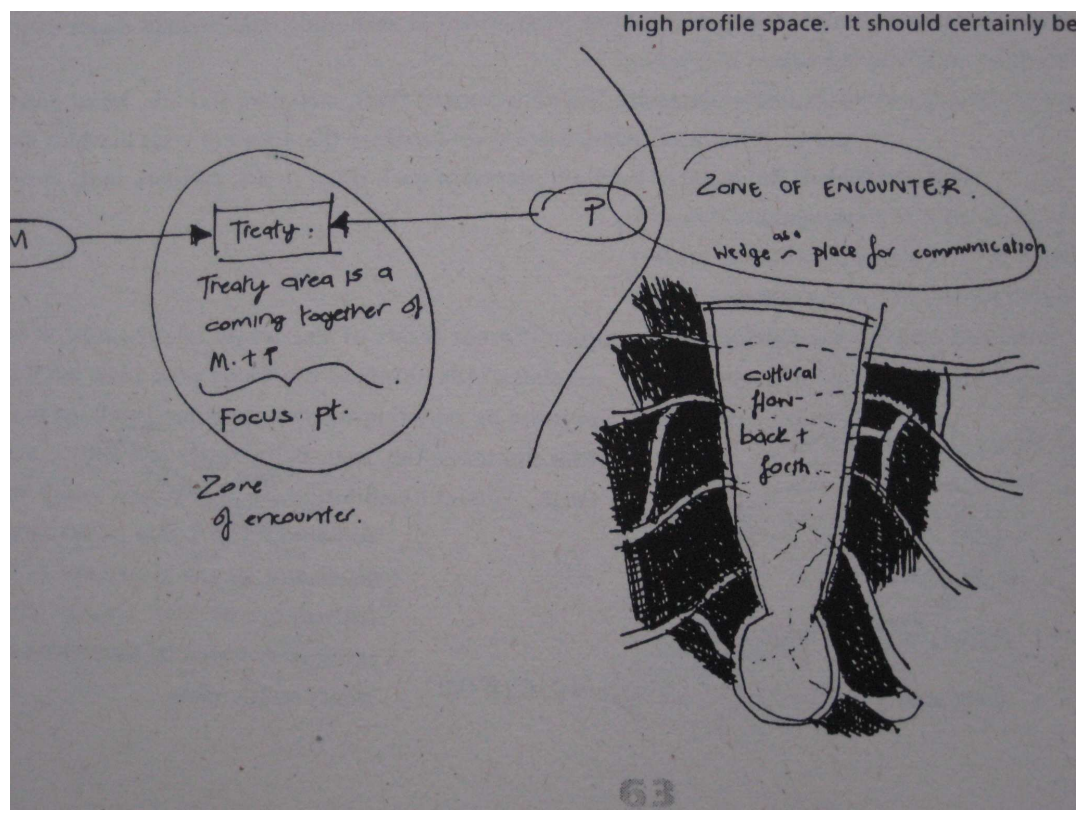

Figure 13: detail sketch of Signs of a Nation exhibition, Exhibitions Conceptual Design 1994, 2008 Photograph Julia Waite.

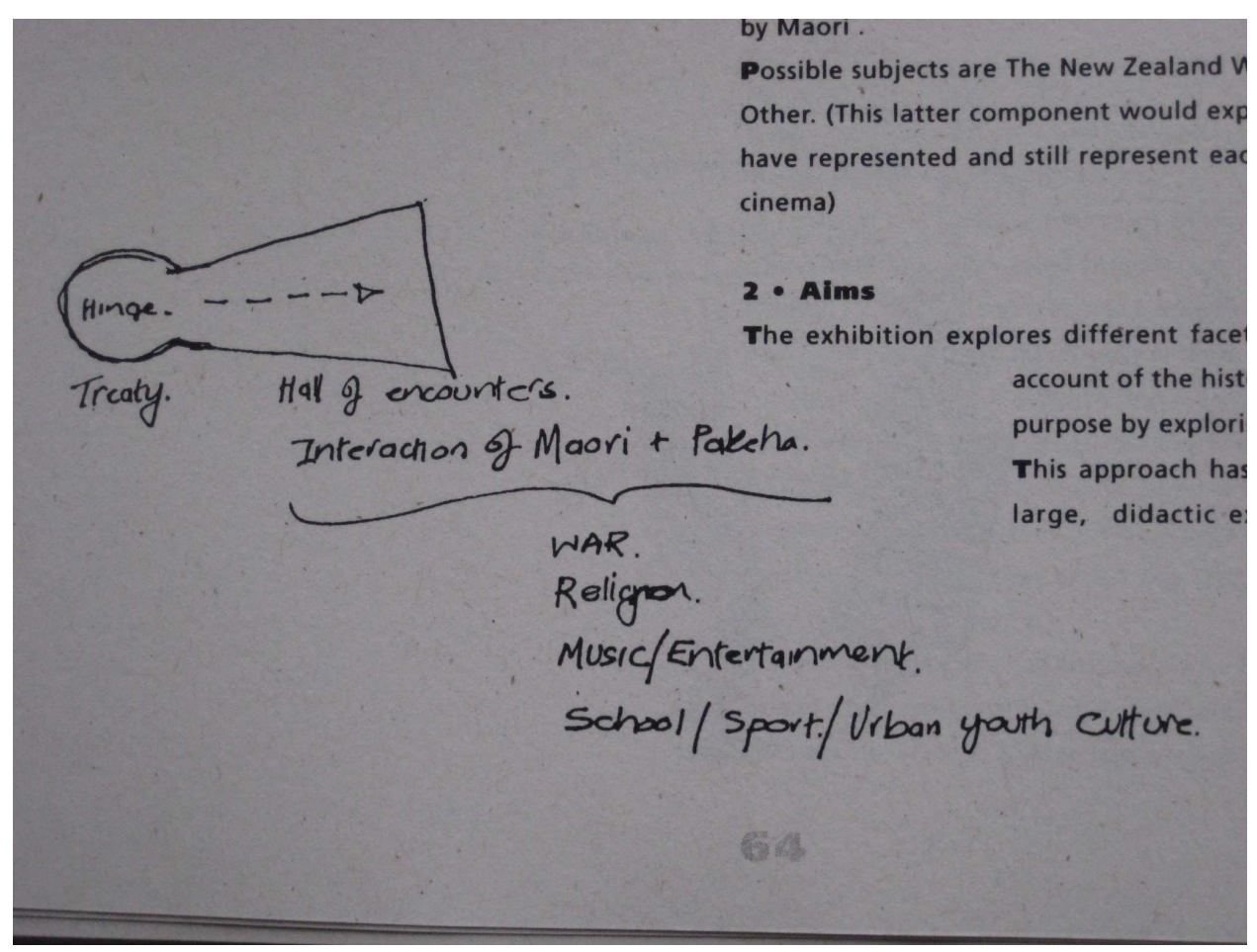

Figure 14: detail sketch of Encounters exhibition, Exhibitions Conceptual Design 1994, 2008. Photograph Julia Waite. 


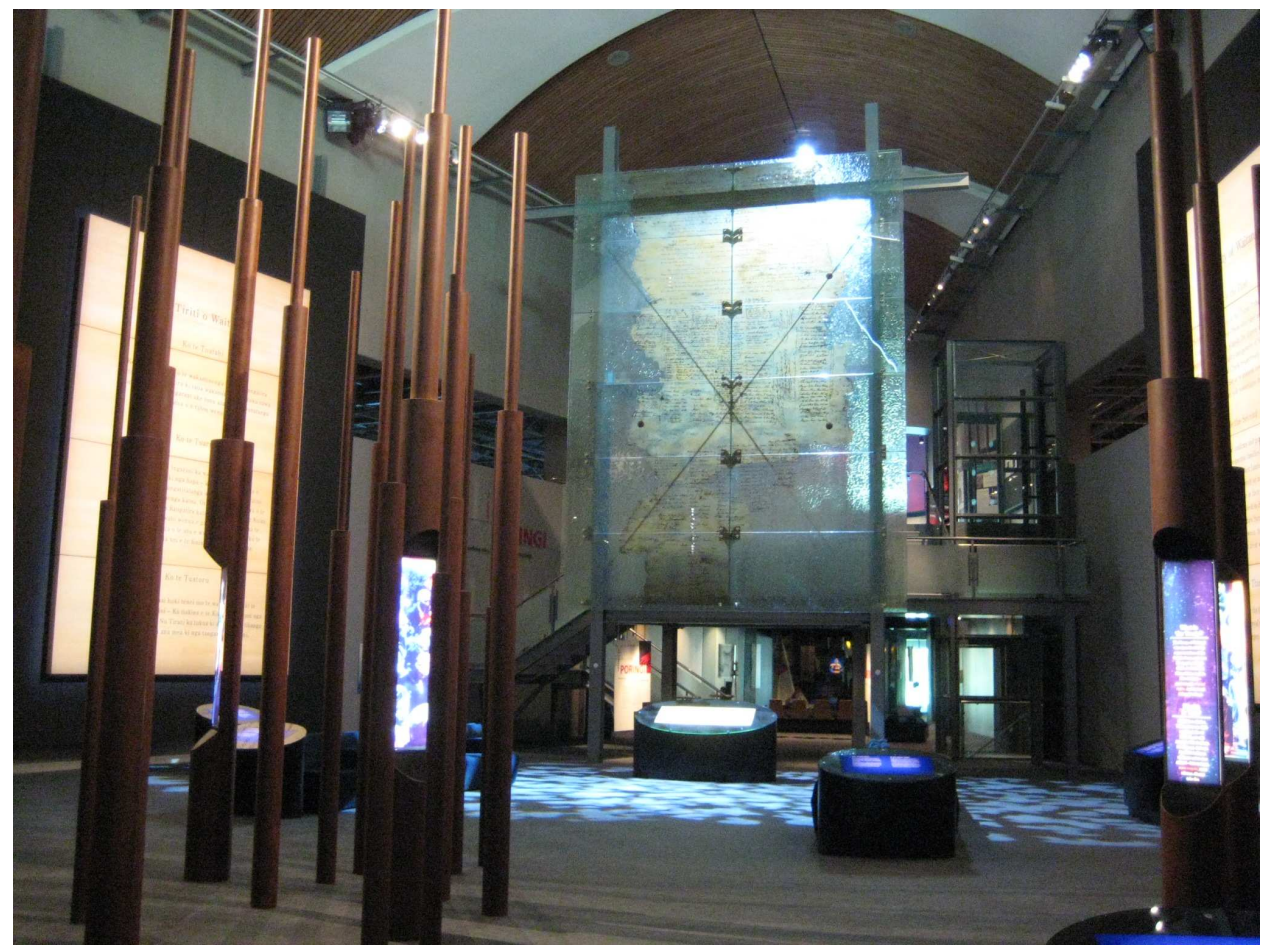

Figure 15: Signs of a Nation exhibition Te Papa, 2009. Photograph Julia Waite.

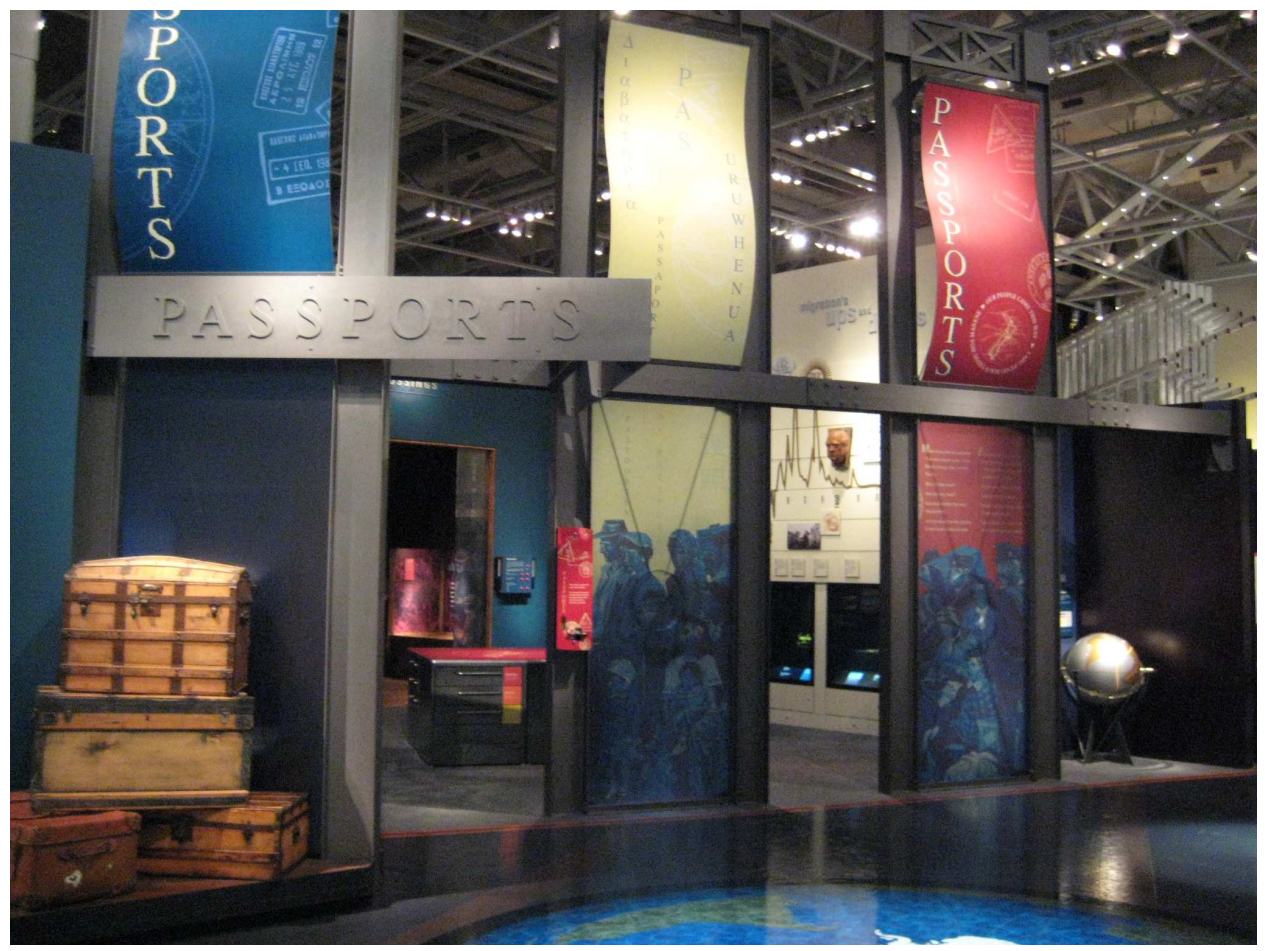

Figure 16: Entrance to Passports exhibition Te Papa, 2009. Photograph Julia Waite. 


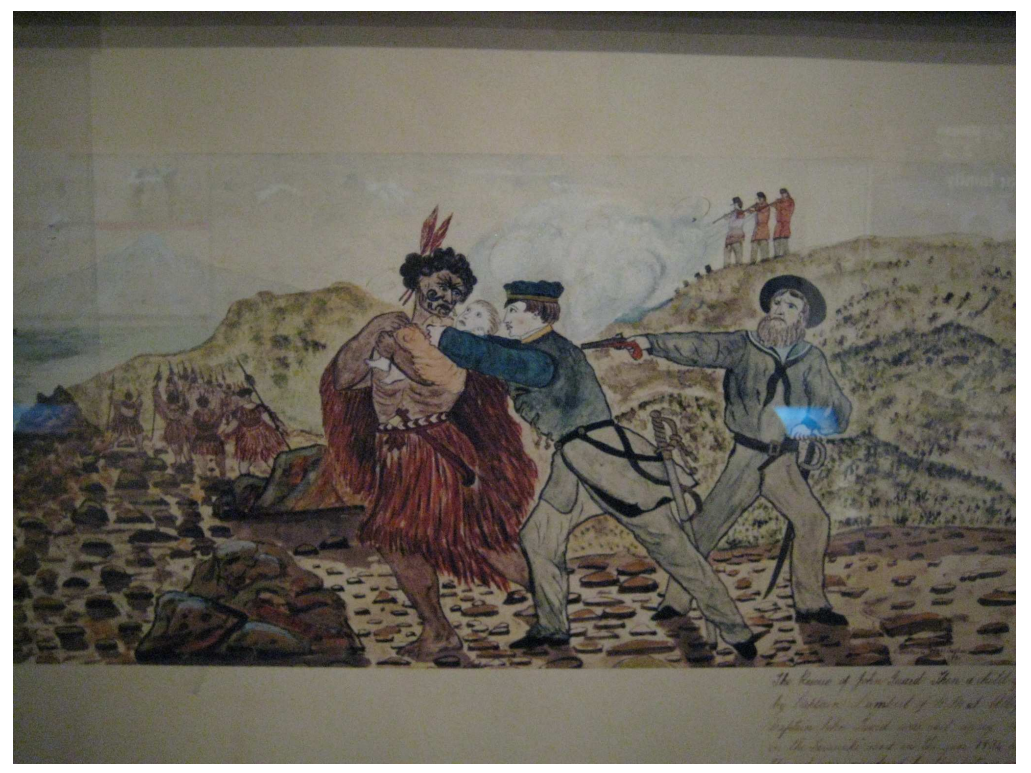

Figure 17: The Rescue of John Guard, C. Watson, 1884, on display in Passports exhibition Te Papa, 2009. Photograph Julia Waite.

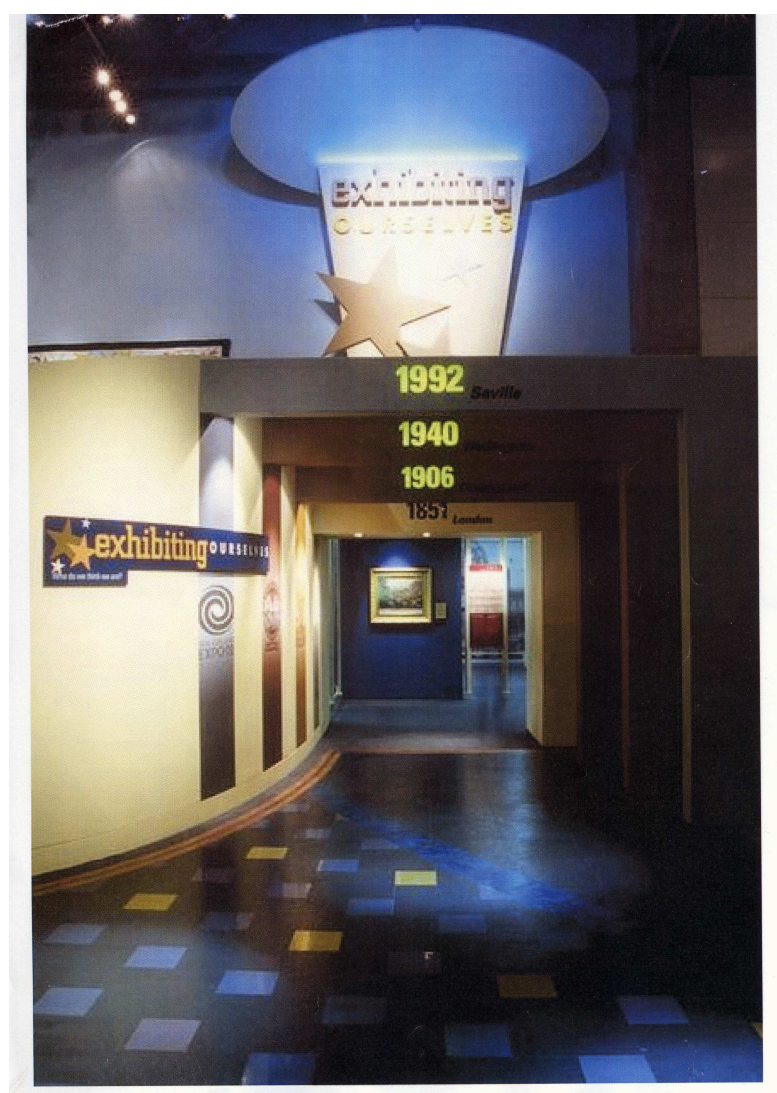

Figure 18: Entrance to Exhibiting Ourselves exhibition Te Papa, 1998. 


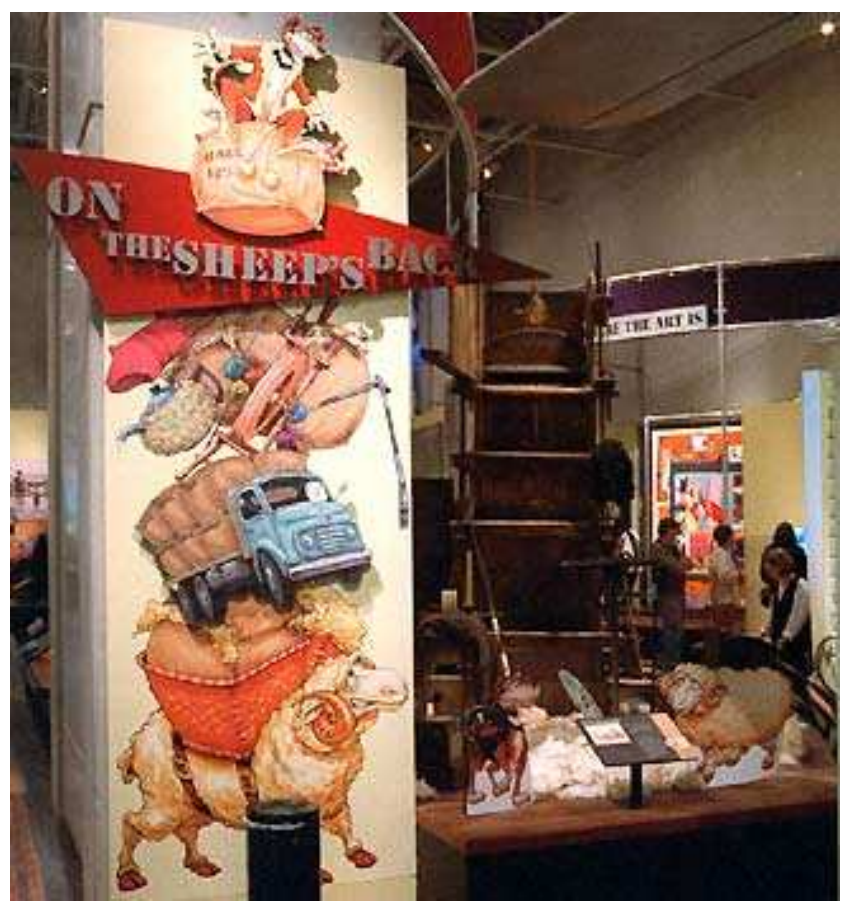

Figure 19: Entrance to On the Sheep's back exhibition Te Papa, 1998. 


\section{Bibliography}

This bibliography is arranged under the following headings:

1. Primary sources:
A. Archival material
B. Interviews
C. Electronic sources
D. Government publications

2. Secondary sources:

A. Books, articles, films and theses

\section{Primary Sources:}

\section{A. Archival material}

$\underline{\text { Te Papa Archives, Te Papa, Wellington }}$

MU000244/001/0002 Michael Fitzgerald: General Subject Files Voices exhibition [previously referred to as Journeys] 1990 - 1993.

MU000259/001/0005 John Walsh: Voices own land, Barretts sources.

MU000259/001/0006 John Walsh: Voices: Waharoa cave, forest sources.

MU000259/001/0007 John Walsh: Voices of Papatuanuku.

MU000263/002/0004 National Art Gallery Raewyn Smith: Exhibition Coordinator/Manager, 1990 - 1991 Our Journey/Voices.

MU000392/002/0002 On The Sheep's Back: Installation Document 1997.

MU000484/002/0008 Monthly Progress reports: Life in New Zealand 1996.

MU000361/018/0006 Passports 90\% Developed Design Part I Interpretation Objects 1996.

MU000361/019/0001 Passports: Object List 1996.

MU000361/019/0004 Passports: Formative Evaluation Study: Interactive Testing for 'Entry Lights Criteria' 1996.

MU000361/019/0005 Peopling of New Zealand 
100\% Design Document Exhibition, subsequently known as Passports 1995.

MU000361/019/0006 Peopling of New Zealand 90\% Concept Design Document Exhibition subsequently known as Passports 1995.

MU000361/020/0001 Peopling of New Zealand: Concept Development Report Exhibition subsequently known as Passports 1995.

MU000361/020/0002 Peopling of New Zealand 30\% Concept Design

Document Exhibition subsequently known as Passports 1995.

MU000361/020/0003 Peopling of New Zealand: Concept Development Report Draft Exhibition subsequently known as Passports. Responses to 90\% Concept

Design Document from Day 1 Management Team9 Jun 1995.

MU000361/020/0004 Peopling of New Zealand: Front End Evaluation Exhibition subsequently known as Passports 1994.

MU000361/020/0006 Exhibiting Ourselves: Concept Development Report 1994.

MU000361/020/0007 Exhibiting Ourselves: Object List.

MU000361/020/0009 Exhibiting Ourselves: 30\% Concept Design Plan 1995.

MU000361/020/0010 Exhibiting Ourselves 90\% Concept Design Plan 1995.

MU000361/020/0011 Exhibiting Ourselves 100\% Concept Design Document 1995.

MU000361/020/0014 Concept Sector comments on the Peopling of New Zealand Concept Development report draft Exhibition subsequently known as Passports 1995.

MU000361/021/0002 Exhibiting Ourselves 90\% Developed Design Part 1 Interpretation and Objects.

MU000361/021/0003 Exhibiting Ourselves 90\% Developed Design Part 2 The Plans 1996.

MU000361/021/0006 Exhibiting Ourselves: Front End Evaluation 1994.

MU000361/023/0007 Treaty of Waitangi Exhibition: Concept

Description 1996.

MU000361/023/0010 Guidelines for Treaty Exhibition.

MU000361/024/0001 Issues to be Addressed by DMIT to Progress Treaty Exhibition. 
MU000438/002/0006 Treaty Exhibition: miscellaneous notes, correspondence, etc 1996 1997.

MU000361/20/14: Concept Sector comments on the Peopling in New Zealand Concept Development Report draft, 7 March, 1995.

MU000361/022/0003 On The Sheep's Back 50\% Developed Design 1996.

MU000361/22/5: Day 1 Front End Evaluation, New Zealand Identity Focus Group Findings.

MU000361/22/6: Day 1 Front End Evaluation, New Zealand Identity Focus Group Findings.

MU000361/026/0006 Life in New Zealand: Concept Development Report 1996.

\section{B. Interviews}

Face-to-face interview, tapes held by author:

Bronwyn Labrum, 5 October 2008, Wellington

Jock Phillips, 17 October 2008, Wellington

Kirstie Ross, 16 October 2008, Wellington

Paul Thompson, 9 October 2008, Wellington

Questionnaires via email, held by author:

Islander Bin Mydin, 2008.

\section{Electronic sources:}

Ministry of Information and the Arts. URL: http://app.mica.gov.sg/, accessed 13 December 2008

Ministry of Manpower. URL: http://www.mom.gov.sg/publish/momportal/en/home.html , accessed 11 November 2008

National Library Board Singapore. URL: http://exhibtions.nlb.gov.sg/bookstobytes accessed 23 March 2008.

Raffles Museum of Biodiversity Research. URL: http://rmbr.nus.edu.sg/, accessed 8 April2009 
Singapore Government Press Release. URL: http://www.gov.sg/pressreleases.htm, accessed 11 November 2008

Singapore Government Homepage. URL: http://www.gov.sg/, accessed 11 November 2008

Singapore Tourism Board. URL: http://app.stb.gov.sg/asp/index.asp?, accessed 13 December 2008

\section{Government publications}

Advisory Council on Culture and the Arts. 1989. Report of the Advisory Council on Culture and the Arts. Singapore: Ministry of Community Development.

Annual Reports (of the Museum of New Zealand Te Papa Tongarewa and its predecessors). 1965-2007.

Annual Reports (of the National Heritage Board, Singapore). 1994-2003

Department of Justice. 1992. Museum of New Zealand Te Papa Tongarewa Act.

Ministry of Information and the Arts. 1995. Singapore Global City for the Arts. Singapore: Ministry of Information and the Arts.

Project Development Team for the National Museum of New Zealand/Te Marae Taonga o Aotearoa. 1985. Nga Taonga o Te Motu: Te Marae Taonga o Aotearoa. Wellington: Department of Internal Affairs.

\section{Secondary Sources:}

\section{A. Books, articles, films and theses}

Allen, G., Anson, C. 2005. The Role of the Museum in Creating Multi-Cultural Identities: Lessons from Canada. New York: The Edwin Mellen Press.

Anderson, B. 1991. Imagined Communities: Reflections on the Origin and Spread of Nationalism. London and New York: Verso.

Anderson, M., Reeves, A. 1994. Contested identities: Museums and the nation in Australia. In Museums and the Making of 'Ourselves', edited by Flora Kaplan, Leicester University Press, London and New York.

Archibald, L. 2007. Museum, Nations, Communities. Wellington: Victoria University of Wellington. 
Ashcroft, B., Griffiths, G. \& Tiffen, H. (Eds.) 2006. The postcolonial studies reader. London, New York: Routledge.

Bazin, G. 2004. From The museum age: Foreword. In Museum studies: An anthology of contexts, edited by B. M. Carbonell. Malden, MA: Blackwell Publishing.

Beier-de Haan, R. 2006. Re-staging histories and identities. In A companion to museum studies, edited by S. Macdonald. Oxford: Blackwell.

Bell, C. 1996. Inventing New Zealand: Everyday Myths of Pakeha Identity. Auckland: Penguin Books.

Belich, James. 1996. Making peoples: A history of the New Zealanders from Polynesian settlement to the end of the nineteenth century. Auckland: Allen Lane, Penguin.

Belich, J. 2001. Paradise reforged: A history of the New Zealanders from the 1880s to the year 2000. Auckland: Allen Lane The Penguin Press.

Bennett, T. 1995. The Birth of the Museum: History, Theory, Politics. London: Routledge.

Bhabha, H. 1996. Postmodernism/Postcolonialism. In Critical terms for art history, edited by R. S. Nelson, \& R Shiff. Chicago: University of Chicago Press.

Billig, M. (1995) Banal Nationalism, London: SAGE Publications.

Boswell, D., \& Evans, J. (Eds.). 1999. Representing the nation: A reader: Histories, heritage and museums. London: Routledge.

Bourdieu, P., Darbel, A., \& Schnapper, D. 2004. Conclusion to The love of art: European art museums and their public (C. Beattie \& N. Merriman, Trans.). In Museum studies: An anthology of contexts, edited by B. M. Carbonell. Malden, MA: Blackwell Publishing Ltd.

Brookfield, F. M. 1989. The New Zealand Constitution. In Waitangi: Maori and Pakeha perspectives of the Treaty of Waitangi, edited by I. H. Kawharu. Auckland: Oxford University Press.

Butts, D. 2002. Maori and museums: The politics of indigenous recognition. In Museums, society, inequality, edited by R. Sandell. London and New York: Routledge.

Cannon-Brookes, P. 1991. Museum, theme parks and heritage experience. In Journal of Museum Management and Curatorship, 10: 351-8.

Carbonell, B. M. 2004. Museum studies: An anthology of contexts. Malden, MA: Blackwell Publishing.

Chakrabarty, D. 1992. Provincializing Europe: Postcoloniality and the Critique of History. In Cultural Studies 6, no. 3: 337-57. 
Chrisman, L., Parry, B. \& English Association. 2000. Postcolonial theory and criticism, Woodbridge, D. S. Brewer.

Connor, W. 2002. Ethnonationalism in the contemporary world: Walker Connor and the study of nationalism. London, New York: Routledge.

Coombes, A. 2006. Rethinking settler colonialism: History and memory in Australia, Canada, Aotearoa New Zealand and South Africa, Manchester: Manchester University Press.

Corrin, L. 2004. Mining the Museum: Artists look at Museum, Museum Look at Themselves. In Museum studies: An anthology of contexts, edited by B. M. Carbonell. Malden, MA: Blackwell Publishing.

Cottrell, A., \& Preston, G. (Writer). 1999. Getting to Our Place [video recording]. Wellington, New Zealand: Gaylene Preston Productions in association with NZ on Air and TVNZ.

Crane, S. 2000. Museum and Memory, California: Stanford University Press.

Crane, S. 2004. Memory, Distortion, and History in the Museum. In Museum studies: An anthology of contexts, edited by B. M. Carbonell. Malden, MA: Blackwell Publishing.

Crampton, A. 2003. The art of nation-building: (re)presenting political transition at the South African National Gallery. In Cultural Geographies 2003; 10; 218 DOI: 10. 1191/1474474003eu270oa

Dalley, B., Phillips, J. 2001. Going Public: The Changing Face of New Zealand History. Auckland: Auckland University Press.

Davison, G. 2006. What should a national museum do? Learning from the world. In, Memory, monuments and museums: The past in the present, edited by M. Lake. Melbourne: Melbourne University Press.

Day, G., Suggett, R. 1985: Conceptions of Wales and Welshness: aspects of nationalism in nineteenth century Wales, in Political Action and Social Identity, edited by G. Rees. London: Macmillan.

Dell, R. K. 1965. The first hundred years of the Dominion Museum. Wellington: Dominion Museum.

Duncan, C., \& Wallach, A. 2004. The Universal Survey Museum. In Museum studies: An anthology of contexts, edited by B. M. Carbonell. Malden, MA: Blackwell Publishing. 
Durie, E. T. J. (1991). ‘The Treaty in Maori history', In Sovereignty \& indigenous rights: The Treaty of Waitangi in international contexts, edited by W. Renwick. Wellington: Victoria University Press.

Durie, M. H. 1989. The Treaty of Waitangi: Perspectives on social policy, in Waitangi: Maori and Pakeha perspectives of the Treaty of Waitangi, edited by I. H. Kawharu. Auckland: Oxford University Press.

Evans, J. \& Boswell, D. 1999. Representing the nation: A reader: Histories, heritage and museums. London, New York: Routledge in association with the Open University.

Featherstone, S. 2005. Postcolonial cultures. Edinburgh: Edinburgh University Press

Fleras, A. 1989. Inverting the bureaucratic pyramid: Reconciling aboriginality and bureaucracy in New Zealand. In Human Organization, 48(3), 214-221.

Fleras, A., \& Spoonley, P. 1999. Recalling Aotearoa: Indigenous politics and ethnic relations in New Zealand. Auckland: Oxford University Press.

Gandhi, L. (Ed.). 1998. Postcolonial theory: A critical introduction. Sydney: Allen and Unwin.

Gore, James. 2002. Representations of history and nation in museums in Australia and Aotearoa New Zealand: The National Museum of Australia and The Museum of New Zealand Te Papa Tongarewa. PhD thesis, History, University of Melbourne. Graham, B. 1993. An Infinity of Voices. In Voices He Putahitanga edited by J.

McCormack, and R. Leonard. MidWest (3): 12-16.

Guibernau, M. 1996. Nationalisms: The Nation-State and Nationalism in the Twentieth Century. Polity Press: Cambridge.

Gurian, E. H. 2004. Singing and dancing at night, in Stewards of the sacred, edited by L. E. Sullivan \& A. Edwards. Washington D.C.: American Association of Museums in cooperation with the Centre for the Study of World Religions, Harvard.

Haas, A. 2003. An interview with Dr Seddon Bennington. Te Ara-Museums Aotearoa, 28(1): 4-6.

Hakiwai, A. T. 2005. The search for legitimacy: Museums in Aotearoa, New Zealand - a Maori viewpoint. In Heritage, museums and galleries: An introductory reader, edited by G. Corsane. London and New York: Routledge.

Hall, S. 1997. Representation: cultural representations and signifying practices. London, Thousand Oaks California: Sage in association with the open university.

Harrison, J. 1993. Ideas of museum in the 1990s. In Heritage, museums and galleries: An introductory reader, edited by G. Corsane. London and New York: Routledge. 
Healy, C. \& Witcomb, A. (Eds.). 2006. South Pacific museums: Experiments in culture, Melbourne: Monash University ePress.

Healy, C. 1997. From the ruins of colonialism: History as social memory, Melbourne, Cambridge University Press.

Henare, A. 2005. Museum, Anthropology and Imperial Exchange. New York: Cambridge University Press.

Ho Tai, H. 1998. Representing the Past in Vietnamese Museums. In Curator 41/3.

Hooper-Greenhill, E. 2004. Changing values in the art museum: Rethinking communication and learning. In Museum studies: An anthology of contexts, edited by B. M. Carbonell. Malden, MA: Blackwell Publishing Ltd.

Hroch, M. 1996. From National Movement to the Fully-formed Nation: The Nationbuilding Process in Europe. In Mapping the Nation, edited by B. Gopal. New York and London: Verso.

Hudson, K. 2004. The museum refuses to stand still. In Museum studies: An anthology of contexts, edited by B. M. Carbonell. Malden, MA: Blackwell Publishing Ltd.

Hurston, Z. N. 2004. What white publishers won't print. In Museum studies: An anthology of contexts, edited by B. M. Carbonell. Malden, MA: Blackwell Publishing Ltd.

Hutchinson, J., Smith, A. 1994. Nationalism. Oxford: Oxford University Press.

Kaplan, F. 2006. Making and remaking national identities, in A companion to museum studies, edited by S. MacDonald. Oxford: Blackwell.

Karp, I. \& Lavine, S. D. (Eds.). 1991. Exhibiting cultures: The poetics and politics of museum display, Washington: Smithsonian Institution Press.

Karp, I., Kratz, C. A. \& Szwaja, L. (Eds.). 2006. Museum Frictions: Public Cultures/Global Transformations Durham, North Carolina: Duke University Press.

Karp, I., Lavine, S. D. \& Mullen Kreamer, C. (Eds.). 1992. Museums and communities: The politics of public culture. Washington: Smithsonian Institution Press.

Kaufman, E. 2004. The Architectural Museum from World's Fair to Restoration Village. In Museum studies: An anthology of contexts, edited by B. M. Carbonell. Malden, MA: Blackwell Publishing.

Kian-Woon, K., Chong Guan, K., Kong, L., Yeoh, B. 1999. Our Place in Time: Exploring Heritage and Memory in Singapore. Singapore: Singapore Heritage Society. 
King, M. 2003. The Penguin History of New Zealand. Auckland: Penguin Books.

Kirshenblatt-Gimblett, B. 1994. Destination Museum: Issues of Heritage, Museums and Tourism, Seminar paper, Wellington City Gallery, Museum Directors Federation of Aotearoa/New Zealand, Wellington.

Kreps, C. F. 2003. Liberating culture: Cross-cultural perspectives on museums, curation and heritage preservation. London: Routledge.

Labrum, B. (2009). The Female Past and Modernity: Displaying Women and Things in New Zealand Department Stores, Expositions and Museum, 1920s-1960s. In Women and things, edited by B. Fowkes-Tobin. London: Ashgate.

Lake, M. (Ed.). 2006. Memory, monuments and museums: The past in the present, Melbourne: Melbourne University Press.

Lee, E. 1986. The Historiography of Singapore. In Singapore Studies; Critical Surveys of the Humanities and Social Sciences, edited by B. Kapu. Singapore: Singapore University Press.

Lenzi, L. 2007. National Museum of Singapore Guide. Singapore: Editions Didier Millet Pte Ltd.

Lepawsky, J. 2008. A museum, the City, and a Nation. In Cultural Geographies 2008; 15; 119. DOI: $10.1177 / 1474474007085781$.

Lidchi, H. 1997. The Poetics and the Politics of Exhibiting other cultures. In Representation: Cultural representations and signifying practices, edited by S. Hall. London; Thousand Oaks, California: Sage in association with the Open University.

Loomba, A., Kaul, S., Bunzl, M., Burton , A. \& Esty, J. (Eds.) 2005. Postcolonial studies and beyond, Durham \& London: Duke University Press.

MacDonald, G. F. 1989. Crossroads of culture: The Canadian museum of civilization. In Toward the 21 st century: New directions for Canada's national museums / en vue $d u$ 21e siècle: Orientation nouvelle des musées nationaux du Canada, edited by L. H. Tepper. Ottawa: Canadian Museum of Civilization.

Macdonald, G. F., \& Alsford, S. 1991. The museum as information utility. In Museum Management and Curatorship, 10(3), 305-311.

MacDonald, G. F. and S. Alsford.1989. A Museum for the Global Village. Ottawa: Canadian Museum of Civilization.

MacDonald, S. (ed.), The Politics of Display: Museums, Science, Culture. London and New York: Routledge. 
MacQueen, N. 2007. Colonialism. London: Longman Publishing Group.

Mahuika, A. T. 1991. Maori culture and the new museum. In Museum Anthropology, 15(4), 9-11.

Mason, Rhiannon. 2006. Cultural theory and museum studies. In A companion to museum studies, edited by S. Macdonald. Oxford: Blackwell.

Mason, R. 2007. Museums, Nations, Identities: Wales and its National Museums. Cardiff: University of Wales Press.

McCarthy, C. 2007. Exhibiting Maori: A History of Colonial Cultures of Display. Wellington: Te Papa Press.

McIntyre, Darryl, and Kirsten Wehner, eds. 2001. Negotiating histories: National museums: Conference proceedings. Canberra: National Museum of Australia.

Macdonald, Sharon. 2006. Expanding museum studies: An introduction. In A companion to museum studies, edited by S. Macdonald. Malden, MA: Blackwell Publishing.

McLean, Fiona. 2007. Museums and the construction of national identity: A review. In The political nature of cultural heritage and tourism: Critical essays, edited by $\mathrm{T}$. Dallen. Aldershot, Hampshire: Ashgate.

McLean, Fiona. 2008. Museums and the representation of identity. In The Ashgate research companion to heritage and identity, edited by B. Graham and $\mathrm{P}$. Howard. Burlington VT: Ashgate.

McLean, G. 2000. Where Sheep May Not Safely Graze: A Brief History of New Zealand's Heritage Movement, 1890-2000. In Common Ground? Heritage and Public Places in New Zealand, edited by in A. Trapeznic. Dunedin: Otago University Press.

Merriman, N. 1989. Museum visiting as a cultural phenomenon. In The new museology, edited by P. Vergo. London: Reaktion Books.

Message, K. 2006. New Museum and the Making of Culture. Oxford: Berg.

Muan, I. 2006. Musing on Museums from Phnom Penh. In Museum Frictions: Public Cultures/Global Transformations, edited by I. Karp, C. A. Kratz \& L. Szwaja. Durham, North Carolina: Duke University Press.

Muise, D. A. 1989. Museums and the Canadian Community: A Historical Perspective. In Toward the 21st Century: new directions for Canada's National Museums / En vue du 2le siècle: orientation nouvelle des musées nationaux du Canada, edited by L. H. Tepper. Ottawa: Canadian Museum of Civilization. 
Newman, A. 2005. Understanding the social impact of museums, galleries and heritage through the concept of capital. In Heritage, museums and galleries: An introductory reader, edited by G. Corsane. London; New York: Routledge.

Pai, M. 1996. Lending Cultural History. In Asian Arts News, March/April 1996: 59-61

Pearce, S. 1992. Making museum meanings. In Museum objects and collections: A cultural study, London: Leicester University Press.

Periwal, S. 1995. Notions of Nationalism, Budapest: Central European University Press.

Phillips, J. 1996. Our history, our selves: The historian and national identity. In New Zealand Journal of History, 30(2): 107-132.

Phillips, J. 2001. The politics of pakeha history in a bicultural museum: Te Papa, the Museum of New Zealand, 1993-98. Paper presented at the National Museum: negotiating histories: conference proceedings, Canberra.

Phillips, R. B. 2006. Show times: De-celebrating the Canadian nation, de-colonising the Canadian museum, 1967-92. In Rethinking settler colonialism: History and memory in Australia, Canada, Aotearoa New Zealand and South Africa, edited by A. Coombs. Manchester: Manchester University Press.

Pieterse, J. N. 2005. Multiculturalism and museums: Discourse about others in the age of globalization. In Heritage, museums and galleries: An introductory reader, edited by G. Corsane. London and New York: Routledge.

Pollock, J. 2005. Graduate Journal of Asia-Pacific Studies 3:1, 84-87

Poole, M. 1986. Industrial Relations: Origins and Patterns of national diversity. London: Routledge.

Prakash, G. (Ed.). 1995. After colonialism: Imperial histories and postcolonial displacements, Princeton, New Jersey: Princeton University Press.

Prystupa, S. (2001). Cross-current of change and the future role of national museums. Paper presented at the national museums: negotiating histories Conference proceedings, Canberra.

Prior, N. 2006. Having one's Tate and eating it: Transformation of the museum in a hypermodern era. In Art and its publics: Museum studies at the millennium, edited by A. McClellan. Oxford: Blackwell Publishing.

Prior, N. 2006. Postmodern restructurings. In A companion to museum studies, edited by S. Macdonald. Oxford: Blackwell.

Prosler, M. 1996. Museums and Globalization. In Theorizing Museums: Representing Identity and Diversity in Changing World, edited by S. Macdonald and G. Fyfe. Oxford and Cambridge: Blackwell. 
Rajaratnam, S. 1972. Singapore: Global City. Singapore: Ministry of Culture Publication.

Renwick, W. 2004. Creating a National Spirit: Celebrating New Zealand's Centennial. Wellington: Victoria University Press.

Schlereth, T. 2004. Collecting Ideas and Artifacts: Common Problems of History Museum and history Texts. In Museum studies: An anthology of contexts, edited by B. M. Carbonell. Malden, MA: Blackwell Publishing.

Simpson, M. G. 1996. Making representations: Museums in the post-colonial era, London and New York: Routledge.

Smith, A. 1991. National Identity. Reno: University of Nevada Press.

Stam, D. 1993. The informed muse: The implications of 'The New Museology' for museum practice. In Heritage, museums and galleries: An introductory reader, edited by G. Corsane. London and New York: Routledge.

Stam, D. 1993. The informed muse: The implications of 'The New Museology' for museum practice. In Heritage, museums and galleries: An introductory reader, edited by G. Corsane, London and New York: Routledge.

Tan Peng Hong, A. 1999. The Past in Present Singapore. In Our Place in Time: Exploring Heritage and Memory in Singapore, edited by K. Kian-Woon, K. Chong Guan, L. Kong and B. Yeoh. Singapore: Singapore Heritage Society.

Tarling, N. 1999. The Cambridge History of Southeast Asia. Cambridge: Cambridge University Press.

Thomas, Nicholas. 1995. A second reflection: Presence and opposition in contemporary Maori art. Journal of the Royal Anthropological Institute (1): 23-46.

Trapeznik, A. 2000. Common Ground? Heritage and Public Places in New Zealand. Dunedin: Otago University Press.

Trocki, C. 2007. Singapore: Wealth, Power and the Culture of Control. London: Routledge.

Turnbull, C. M. 1989. A History of Singapore 1819-1988. Singapore: Oxford University Press.

Velayutham, S. 2007. Responding to Globalization: Nation, Culture and Identity in Singapore. Singapore: ISEAS Publishing.

Vergo, P. (Ed.). 1989. The new museology. London: Reaktion Books.

Ward, M. 1996. What's important about the History of Modern Art Exhibitions? In Thinking About Exhibitions, edited by R. Greenberg, B. Ferguson and S. Nairne. London and New York: Routledge. 
Watson, R. 1998. Tales of Two Chinese history Museum: Taipei and Hong Kong. In Curator: The Museum Journal (41) 3.

Walsh, K. 1992. The representation of the past. London: Routledge.

Wedde, I. 1993. The Delft Effect. In Voices He Putahitanga, edited by J. McCormack. And R. Leonard. MidWest (3): 12-16.

Whyte, R. 1993. Work in Progress. In Voices He Putahitanga, edited by J. McCormack. And R. Leonard. MidWest (3): 12-16.

Williams, P. 2003. Te Papa: New Zealand's identity complex. In The Journal of New Art history, 24(1), 11-24.

Witcomb, A. 2003. Re-Imagining the Museum. London: Routledge.

Young, M., Zuelow, E., Sturm, A. 2007. Nationalism in a Global Era: The Persistence of Nations. London: Routledge. 
